\title{
Targeting Regorafenib-Induced Toxicity through Inhibition of Gut Microbial $\beta$-Glucuronidases
}

Samantha M. Ervin'1, Ronan P. Hanley², Lauren Lim¹, William G. Walton¹, Kenneth H. Pearce ${ }^{2}$, Aadra P. Bhatt ${ }^{3}$, Lindsey I. James ${ }^{2}$, and Matthew R. Redinbo ${ }^{1,4^{*}}$

\section{Supporting Information}

Materials and methods..................................................... 2

Supporting Tables.............................................................. 23

Supporting Figures............................................................. 26

Supplemental References...................................................... 


\section{Materials and Methods}

Gene synthesis, expression, and purification of GUSs. Genes for Fp2GUS, Rh2GUS, Rg3GUS, and H11G11 and the 27 other GUS enzymes tested here were synthesized by BioBasic and incorporated into a pLIC-His vector via ligation independent cloning, and resultant plasmids were transformed into BL21-G E. coli cells. Glycerol stocks were made from overnight cultures and snap frozen and stored at $-80^{\circ} \mathrm{C}$. Verification of successful transformation and sample integrity were determined by DNA sequencing. As outlined below, expression and purification were identical for each of the 31 enzymes, and all showed $>95 \%$ final purity by SDSPAGE analysis.

Cultures of $100 \mathrm{~mL}$ LB with ampicillin were inoculated with glycerol stock and incubated overnight at $37^{\circ} \mathrm{C}$ with shaking at $225 \mathrm{rpm}$. For protein expression, $50 \mathrm{~mL}$ of the overnight, approximately $40 \mu \mathrm{L}$ Antifoam 204 , and $750 \mu \mathrm{L}$ of $2000 \mathrm{x}$ ampicillin were added to $1.5 \mathrm{~L} \mathrm{LB}$ in a $2.5 \mathrm{~L}$ Erlenmeyer flask and incubated at $37^{\circ} \mathrm{C}$ at $225 \mathrm{rpm}$. At an OD of approximately 0.6 , the temperature was reduced to $18^{\circ} \mathrm{C}$ and induced with IPTG $(100 \mu \mathrm{M})$ and incubated overnight with shaking at $225 \mathrm{rpm}$. Cultures were spun down in a Sorvall Instruments RC-3B centrifuge at $4500 \mathrm{~g}$ for $25 \mathrm{~min}$ in $1 \mathrm{~L}$ round, flat bottom plastic bottles. Cultures were resuspended in LB and transferred to a 50-mL falcon tube and spun down in a ThermoScientific Sorvall ST 40R centrifuge for $15 \mathrm{~min}$ at $5000 \mathrm{~g}$. Supernatant was discarded and proteins were stored at $-80^{\circ} \mathrm{C}$ until purification.

Cell pellets were lysed in $30 \mathrm{~mL}$ Nickel A buffer [20 mM KH $\mathrm{PO}_{4}, 500 \mathrm{mM} \mathrm{NaCl}, 50 \mathrm{mM}$ imidazole ( $\mathrm{pH}$ 7.4)] with DNase, lysozyme, and a Roche EDTA-free protease inhibitor tablet. The resultant cell slurry was sonicated on a Fischer Scientific Sonic dismembrator model 500 twice with $1 \mathrm{~s}$ pulses for $1.5 \mathrm{~min}$. The resultant lysate was subsequently spun down on a Beckman Coulter J2-HC centrifuge for $1 \mathrm{~h}$ at $17,000 \mathrm{rpm}$. The supernatant was subject to filtration with a $0.22-\mu \mathrm{m}$ filter prior to purification.

Protein was first purified with an Aktaxpress FPLC (Amersham Bioscience) via a Ni NTA column. Protein was eluted in one step using Nickel B buffer $\left[20 \mathrm{mM} \mathrm{KH}_{2} \mathrm{PO}_{4}, 500 \mathrm{mM} \mathrm{NaCl}\right.$, $500 \mathrm{mM}$ imidazole ( $\mathrm{pH}$ 7.4)]. The eluent was then subject to size exclusion chromatography on a HiLoadTM 16/60 Superdex 200 gel filtration column. Size exclusion buffer was utilized for elution [20 mM Hepes, $50 \mathrm{mM} \mathrm{NaCl}(\mathrm{pH}$ 7.4)]. Fractions were collected and an SDS-PAGE gel was performed to assess purity and stability of the enzyme. Protein concentration was determined on an ND-1000 spectrophotometer and then snap frozen in liquid nitrogen and stored at $-80^{\circ} \mathrm{C}$.

Site-directed mutagenesis of GUSs. All mutants were created via site-directed mutagenesis. Mutagenesis primers were synthesized by Integrated DNA technologies. Mutant plasmids were sequenced by Eton Bioscience to confirm successful mutagenesis. Primers used in this study are as follows:

\begin{tabular}{|l|l|l|}
\hline & FW Primer & RV Primer \\
\hline M417A & ggttgtgcatatcgcacgcagaaacaaccgccatagtgg & ccactatggcggttgtttctgcgtgcgatatgcacaacc \\
\hline V415W & gtgcatatcgcacatagaccaaaccgccatagtggtcagacgg & ccgtctgaccactatggcggtttggtctatgtgcgatatgcac \\
\hline M382A & ctgcttcgccgctcgcggtaatttcgttggacagg & cctgtccaacgaaattaccgcgagcggcgaagcag \\
\hline G441W & attcatgctggtatcacccagtaccagccgaagtagtg & cactacttcggctggtactggggtgataccagcatgaat \\
\hline S344W & cgttttcatgtgctgccaaatgtacgggatttccgccc & gggcggaaatcccgtacatttggcagcacatgaaaaacg \\
\hline STP641 & tacttccaatccaatgcgatgcgtgaaatcttcaacctgaacgaaaaatgggcgttc & ttatccacttccaatgcctaatatgcctcgttaaattttccactttttgatgaactctcgtcg \\
\hline
\end{tabular}


Determination of GUS reactivity. To assess the activities of 31 WT GUS enzymes we measured their ability to hydrolyze the fluorescent reporter substrate 4-MUG and regorafenibglucuronide. Reactions were performed in black Costar 96-well plates with a flat, clear bottom, and reaction volumes were as follows: $10 \mu \mathrm{L}$ buffer [25 mM Hepes, $25 \mathrm{mM} \mathrm{NaCl},(\mathrm{pH} 6.5)$, $10 \mu \mathrm{L}$ GUS (15 nM final), and $30 \mu \mathrm{L} 4-\mathrm{MUG} /$ regorafenib-glucuronide at $500 \mu \mathrm{M}$. Reactions were initiated by addition of substrate. For initial determination of protein viability, enzyme and substrate were incubated for 15 minutes, after which a relative fluorescence unit was recorded. All enzymes exhibited activity above background [(-) GUS] and were thus considered catalytically active.

In vitro kinetic assay for catalytic efficiency determination of GUSs. To assess the activities of WT and mutant GUSs, we measured their ability to hydrolyze the fluorescent reporter substrate 4-MUG and regorafenib-glucuronide. Regorafenib-N- $\beta$-D-glucuronide sodium salt and 4-Methylumbelliferyl- $\beta$-D-glucuronide were purchased as solids (Toronto Research Chemicals) and resuspended in DMSO to a concentration of $10 \mathrm{mM}$. Reactions were performed in black Costar 96-well plates with a flat, clear bottom, and reaction volumes were as follows: $10 \mu \mathrm{L}$ buffer [25 mM Hepes, $25 \mathrm{mM} \mathrm{NaCl}$, (pH 6.5)], $10 \mu \mathrm{L}$ GUS (15 nM final), and $30 \mu \mathrm{L} \mathrm{4-}$ MUG/regorafenib-glucuronide at $500 \mu \mathrm{M}$. Reactions were initiated by addition of substrate. All reactions were continuously monitored with excitation at $350 \mathrm{~nm}$ and emission at $450 \mathrm{~nm}$ in a BMG Labtech PHERAstar plate reader for 4-MUG assay. Reactions were continuously monitored with excitation at $300 \mathrm{~nm}$ and emission at $380 \mathrm{~nm}$ in a TECAN infinite M1000PRO plate reader for regorafenib-glucuronide assay. Initial velocities at substrate concentrations between 50-120 $\mu \mathrm{M}$ from the resultant data were fit by linear regression with a custom MATLAB program to obtain catalytic efficiency data.

LOPAC High Throughput Screening. Assays were performed in Greiner 384 well plates and reaction volumes were as follows: $25 \mu \mathrm{L}$ Rg3GUS diluted in buffer [25 mM Hepes, $25 \mathrm{mM} \mathrm{NaCl}$ (pH 6.5) and $1 \mathrm{mM}$ CHAPS], and $40 \mu \mathrm{M}$ final 4-MUG. Plates were pre-stamped with $1 \mathrm{mM}$ compound for a final assay volume of $50 \mathrm{uL}$ (for $20 \mathrm{uM}$ final compound and $2 \%$ DMSO). Test compounds were in the middle 320 wells with columns 1, 2, 23, 24 reserved for high and low controls and a control dose response curve. Percent inhibition for test compounds was determined using data from control columns. Enzyme was pre-incubated with compound, then reactions were initiated by addition of substrate. After 8 minutes, reactions were quenched with $50 \mathrm{uL}$ Sodium Carbonate. Following quenching, plates were read with excitation at $350 \mathrm{~nm}$ and emission at $450 \mathrm{~nm}$ in an Enspire plater reader (Perkin Elmer). Controls included $\mathrm{IC}_{50}$ with a known pan-GUS inhibitor, saccharolactone, and -GUS/-Compound controls (substituted with DMSO). 4-MUG assay was validated with Z' scores of $>0.8$ for Rg3GUS. Buffer optimization, day-to-day reproducibility, DMSO tolerance, volume miniaturization, and use of liquid handling lab automation all were conducted to pharmaceutical industry standards (data not shown).

In vitro inhibition assay. All analog-by-catalog compounds were purchased through Cayman Chemical as solid and dissolved in DMSO for $10 \mathrm{mM}$ stock concentrations. In vitro inhibition of bacterial GUS enzymes was assessed as previously described $(22,23)$. Reactions consisted of $10 \mu \mathrm{L}$ of GUS (15 nM final), $5 \mu \mathrm{L}$ of inhibitor (various concentrations), $30 \mu \mathrm{L}$ of 4-MUG (900 $\mu \mathrm{M}$ 
final), and $5 \mu \mathrm{L}$ of assay buffer [25 mM NaCl, $25 \mathrm{mM} \mathrm{HEPES,} \mathrm{(pH} \mathrm{6.5)].} \mathrm{Reactions} \mathrm{were} \mathrm{initiated}$ by addition of 4-MUG and then incubated for 1 hour, after which the end point absorbance was determined. Percent inhibition values were subsequently plotted against the log of inhibitor concentration and fit with a four-parameter logistic function in SigmaPlot 13.0 to determine the $I C_{50}$. Due to the slow binding nature of the piperazine and piperidine compounds, the $I_{50}$ was determined as the inhibitor concentration that yielded at $50 \%$ reduction in the maximum absorbance of the uninhibited reaction where percent inhibition was calculated as:

Where $A_{\text {exp }}$ is the end point absorbance at a particular inhibitor concentration, $A_{\max }$ is the absorbance of the uninhibited reaction and $A_{b g}$ is the background absorbance in the assay. Percent inhibition values were subsequently plotted against the log of the inhibitor concentration and fit with a four-parameter logistic function in SigmaPlot 13.0 to determine the $\mathrm{IC}_{50}$.

$$
\% \text { inhibition }=\left[1-\left(\frac{A_{\text {exp }}-A_{b g}}{A_{\max }-A_{b g}}\right)\right] \times 100
$$

In vitro inhibition of bacterial GUS enzymes by non-piperazine/piperidine-containing inhibitors were determined using the reaction conditions described above, but the $\mathrm{IC}_{50}$ was determined as the inhibitor concentration that yielded $50 \%$ reduction in the maximum initial velocity of the uninhibited reaction.

Regorafenib-Glucuronide processing assay in intestinal homogenates. All animal studies were approved by the University of North Carolina Institutional Animal Care and Use Committee (IACUC), in accordance with the Care and Use of Laboratory Animals guidelines set by the National Institutes of Health. 12-14-week old C57BL/6J mice were individually housed in a specific pathogen-free (SPF) vivarium in sterile ventilator cages containing corn bedding. Germfree C57/BL6J mice were bred in flexible film isolators ventilated via HEPA-filtered air. All animals were maintained at $22 \pm 1{ }^{\circ} \mathrm{C}$ with a 12-h light/dark cycle, and ad libitum access to chow and water. Animals were deeply anesthetized with $\mathrm{CO}_{2}$ followed by manual cervical dislocation. First, the entire gastrointestinal tract from duodenum to anus was excised and rinsed with sterile PBS. The small intestine was separated at the ileocecal joint, apportioned into segments, and placed into sterile microfuge tubes. The cecum was separated from the colon, and both were collected into separate tubes. $1 \mathrm{ml}$ of NP40 buffer containing 1x Complete Protease Inhibitor cocktail (Roche) was used per $20 \mathrm{mg}$ of tissue, and all samples were kept on ice.

After the tissue was dissected it was transferred to a mechanical shear homogenizer and 500 $\mu \mathrm{L}$ NP-40 buffer + protease inhibitor was added for every $10 \mathrm{mg}$ of tissue. Homogenization protocol adapted from Simpson (1). Tissues were homogenized thoroughly using a mechanical shear homogenizer, three times for 20-30 sec each, pausing for 10-15 sec between each homogenization, and then kept on ice for 30 minutes, vortexing occasionally to allow further extraction of proteins. Then the samples were sonicated for 5 five minutes at 180 watts (in rounds of 10 seconds sonication/10 seconds rest for each cycle) to break the tissue up further and to shear DNA. Samples were kept on ice during sonication. Samples were centrifuged at $13,000 x g$ for 10 minutes to remove cell debris and particulate matter, then snap frozen in liquid nitrogen to be stored at $-80^{\circ} \mathrm{C}$.

To perform the assay, frozen homogenized tissue and fecal samples were rehydrated in $15 x$ assay buffer (weight/volume; $20 \mathrm{mM}$ HEPES, $50 \mathrm{mM} \mathrm{NaCl}$, [pH 5.5 for samples from the cecum and $\mathrm{pH} 6.5$ from small and large intestinal samples], $1 \times$ Complete $®$ Protease inhibitor cocktail 
(Roche)). Homogenate was sonicated for $4 \mathrm{~min}$, and then clarified by centrifugation for 10 minutes at $13,000 \times \mathrm{g}$. All experimental manipulation until this point occurred at $4{ }^{\circ} \mathrm{C}$. In vitro assays were conducted at $37^{\circ} \mathrm{C}$ in a $50 \mu \mathrm{L}$ total volume. $25 \mu \mathrm{L}$ of intestinal slurry supernatant was used to initiate the hydrolysis reaction of $5 \mathrm{mM}$ regorafenib-glucuronide resuspended in the same buffer. The inhibition assays consisted of $5 \mu \mathrm{L}$ inhibitor, $25 \mu \mathrm{L}$ supernatant, and $20 \mu \mathrm{L}$ substrate. Parallel reactions containing only regorafenib-glucuronide or only buffer/intestinal slurry were used as negative controls. Each sample was assayed using three technical replicates. Reactions were incubated at $37^{\circ} \mathrm{C}$ over 48 hours and quenched with $50 \mu \mathrm{L}$ of $25 \%$ trichloroacetic acid (TCA) at 4, 8, 12, 24 and 48 hours. After centrifugation at 13,000xg for 10 min, the resultant supernatant was subjected to HPLC analysis. The concentration of regorafenib-glucuronide remaining after each timepoint was quantified on a Agilent 1260 Infinity II liquid chromatograph system. Samples were separated on an Agilent InfinityLab Poroshell $120 \mathrm{C} 18$ column $(4.6 \times 100 \mathrm{~mm}, 2.7 \mu \mathrm{m}$ particle size $)$ at $38^{\circ} \mathrm{C}$. The flow rate was $0.9 \mathrm{~mL} / \mathrm{min}$, and the injection volume was $10 \mu \mathrm{L}$. LC conditions were set at $98 \%$ water with $0.1 \%$ formic acid (A) for 2 mins, then ramped linearly over 10 mins to $98 \%$ acetonitrile with $0.1 \%$ formic acid (B) and held until 14 mins. At 15 mins the gradient was switched back to $100 \%$ A and allowed to reequilibrate until 17 mins. Regorafenib-G was monitored at $280 \mathrm{~nm}$. The concentration of regorafenib was determined from a standard curve (0-500 $\mu \mathrm{M}$ regorafenib in assay buffer).

Bacterial survival assays: Two bacterial strains with distinct growth requirements were used to test whether raloxifene analogs affect bacterial cell growth. Ruminococcus gnavus (ATCC 29149) was cultured anaerobically in Reduced Clostridial Medium (RCM; Gibco). Log phase bacteria were diluted to OD600 of 0.1 , placed in fresh RCM media containing $10 \mathrm{uM}$ of raloxifene analogs, and cultured for 24 hours. The OD600 was measured to quantify growth rate. Cell viability was assessed by plating limiting dilutions on RCM agar, and quantifying bacterial colonies. E. coli (ATCC 700926) was cultured aerobically in LB medium. Log phase bacteria were diluted to OD600 of 0.3 , placed in fresh LB media containing $10 \mathrm{uM}$ of raloxifene analogs, and cultured for 16 hours. The OD600 was measured to quantify growth rate. Cell viability was assessed by plating limiting dilutions on LB agar and quantifying bacterial colonies.

SSN construction. The sequence similarity network diagram of GUS enzyme sequences was generated using the enzyme function initiative-enzyme similarity tool (EFI-EST) online tool (26). The sequences obtained from the GUS rubric were used in combination with the EFI-EST "FASTA" tool to create a sequence with 279 nodes. Each node represents sequences bearing $\geq 90 \%$ sequence identity to each other. A BLAST E-value of $1 \times 10^{-220}$ was employed.

CD analysis of GUS mutants. The protein stabilities of the WT and mutant GUS enzymes described above were determined using the Circular Dichroism method (2). Enzyme $(2.5 \mu \mathrm{M})$ in CD buffer containing $10 \mathrm{mM}$ potassium phosphate $(\mathrm{pH} \mathrm{7.4)}$ ) and $100 \mathrm{mM}$ potassium fluoride was loaded into a 1-mm pathlength cuvette. Using a Chirascan-plus instrument (Applied Photophysis Limited), spectra from 185 to $260 \mathrm{nM}$ were recorded at $20 \pm 1.0^{\circ} \mathrm{C}$. Measurements were corrected for background signal using a CD buffer sample. The melting profile of the sample $(2.5 \mu \mathrm{M})$ was monitored at $228 \mathrm{~nm}$ from $20^{\circ} \mathrm{C}$ to $94^{\circ} \mathrm{C}$.

\section{General Chemistry Procedures}

Reactions were carried out using conventional glassware. All reagents and solvents were used as received unless otherwise stated. Reagents were of $95 \%$ purity or greater, and solvents were 
reagent grade unless otherwise stated. Any anhydrous solvents used were purchased as "anhydrous" grade and used without further drying. "Room" or ambient temperature varied between $20-25^{\circ} \mathrm{C}$. Analytical thin layer chromatography (TLC) was carried out using glass plates pre-coated with silica gel (Merck) impregnated with fluorescent indicator (254 nm). TLC plates were visualized by illumination with a $254 \mathrm{~nm}$ UV lamp. Analytical LCMS data for all compounds were acquired using an Agilent 1260 Infinity II system with the UV detector set to $254 \mathrm{~nm}$. Samples were injected $(<10 \mu \mathrm{L})$ onto an Agilent ZORBAX Eclipse Plus C18, 600 Bar, $4.6 \times 50$ $\mathrm{mm}, 1.8 \mu \mathrm{M}$ column at $25.0^{\circ} \mathrm{C}$. Mobile phases $\mathrm{A}\left(\mathrm{H}_{2} \mathrm{O}+0.1 \%\right.$ acetic acid $)$, $\mathrm{B}(\mathrm{MeOH}+0.1 \%$ acetic acid), and $\mathrm{C}\left(99 \% \mathrm{MeCN}+1 \% \mathrm{H}_{2} \mathrm{O}+0.1 \%\right.$ acetic acid) were used with a linear gradient from $10 \%$ to $100 \%$ B or C in 5.0 min, followed by a flush at $100 \%$ B or C for another 2 minutes with a flow rate of $1.0 \mathrm{~mL} / \mathrm{min}$. Mass spectra (MS) data were acquired in positive ion mode using an Agilent InfinityLab LC/MSD single quadrupole mass spectrometer with an electrospray ionization (ESI) source. Normal phase column chromatography was performed with a Teledyne Isco CombiFlash ${ }^{\circledR} R_{f} 200$ using RediSep ${ }^{\circledR} R_{f}$ SILICA columns with the UV detector set to $254 \mathrm{~nm}$ and $280 \mathrm{~nm}$. Reverse phase column chromatography was performed with a Teledyne Isco CombiFlash $\AA_{\mathrm{f}} 200$ using $\mathrm{C} 18$ RediSep $\mathrm{BR}_{\mathrm{f}}$ Gold columns with the UV detector set to $220 \mathrm{~nm}$ and $254 \mathrm{~nm}$. Analytical LCMS (at $254 \mathrm{~nm}$ ) was used to establish the purity of targeted compounds. Unless otherwise noted, all compounds that were evaluated in biochemical and biophysical assays had $>95 \%$ purity as determined by LCMS.

\section{Nuclear Magnetic Resonance Spectroscopy (NMR)}

${ }^{1} \mathrm{H},{ }^{13} \mathrm{C}$, and ${ }^{19} \mathrm{~F}$ NMR spectra were obtained on a Varian $400 \mathrm{MR}$ at $400 \mathrm{MHz}, 100 \mathrm{MHz}$, and $376 \mathrm{MHz}$ respectively. Chemical shifts are reported in ppm and coupling constants are reported in $\mathrm{Hz}$ with $\mathrm{CDCl}_{3}$ referenced at $7.26\left({ }^{1} \mathrm{H}\right)$ and $77.1 \mathrm{ppm}\left({ }^{13} \mathrm{C}\right)$, DMSO- $d_{6}$ referenced at $2.50\left({ }^{1} \mathrm{H}\right)$ and $39.5 \mathrm{ppm}\left({ }^{13} \mathrm{C}\right)$, acetone- $d_{6}$ referenced at $2.05\left({ }^{1} \mathrm{H}\right)$ and $29.8 \mathrm{ppm}\left({ }^{13} \mathrm{C}\right)$, and MeOD- $d_{4}$ referenced at $3.31\left({ }^{1} \mathrm{H}\right)$ and $49.0 \mathrm{ppm}\left({ }^{13} \mathrm{C}\right)$.

\section{High Resolution Mass Spectrometry}

Samples were analyzed with a Q Exactive HF-X (ThermoFisher, Bremen, Germany) mass spectrometer. Samples were introduced via a heated electrospray source (HESI) at a flow rate of $10 \mu \mathrm{L} / \mathrm{min}$. One hundred time domain transients were averaged in the mass spectrum. HESI source conditions were set as: nebulizer temperature 100 deg C, sheath gas (nitrogen) 15 arb, auxillary gas (nitrogen) 5 arb, sweep gas (nitrogen) 0 arb, capillary temperature 250 degrees $C$, RF voltage $100 \mathrm{~V}$, spray voltage $3.5 \mathrm{KV}$. The mass range was set to $150-2000 \mathrm{~m} / \mathrm{z}$. All measurements were recorded at a resolution setting of 120,000 . Solutions were analyzed at 0.1 $\mathrm{mg} / \mathrm{mL}$ or less based on responsiveness to the ESI mechanism. Xcalibur (ThermoFisher, Breman, Germany) was used to analyze the data. Molecular formula assignments were determined with Molecular Formula Calculator ( $v$ 1.2.3). All observed species were singly charged, as verified by unit $\mathrm{m} / \mathrm{z}$ separation between mass spectral peaks corresponding to the ${ }^{12} \mathrm{C}$ and ${ }^{13} \mathrm{C}^{12} \mathrm{C}_{\mathrm{c}-1}$ isotope for each elemental composition.

\section{Compounds Derived from Commercial Raloxifene Hydrochloride ( $\mathrm{TCl}$ )}

UNC7081 and UNC7082 (Raloxifene methylation) 
CAUTION! TMS-diazomethane is volatile and extremely toxic! Use only in a fume hood, avoid any skin exposure, reglove often, and quench all equipment with dilute acid.

To a $25 \mathrm{~mL}$ flask was added Raloxifene hydrochloride $(0.26 \mathrm{~g}, 1 \mathrm{Eq}, 0.50 \mathrm{mmol})$, acetonitrile $(4.5 \mathrm{~mL})$, and methanol $(0.5 \mathrm{~mL})$, which were stirred to a slurry. Next was added DIPEA $(0.19 \mathrm{~g}$, $0.26 \mathrm{~mL}, 3 \mathrm{Eq}, 1.5 \mathrm{mmol}$ ), resulting in a mostly-homogeneous, bright yellow solution. A septum and nitrogen flow were added, and TMS-diazomethane (2M in hexanes, $0.25 \mathrm{~mL}, 1 \mathrm{Eq}, 0.50$ $\mathrm{mmol}$ ) was added dropwise. The needle and syringe were rinsed thoroughly with acetic acid diluted in methanol. The reaction was left to stir overnight, resulting in some precipitation at the bottom of flask. The next day, the reaction was quenched with a few drops of acetic acid and the volatiles were removed by rotary evaporation. The residue was purified by reverse-phase chromatography $(10-100 \%$ methanol in water $+0.1 \%$ TFA) to yield mostly unreacted raloxifene plus small quantities of the two monomethylated products, UNC7081 and UNC7082. Regiochemistry was determined by 2D NMR (HSQC and HMBC).

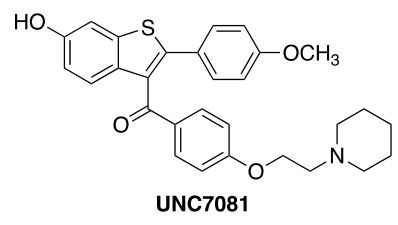

UNC7081: (6-hydroxy-2-(4-methoxyphenyl)benzo[b]thiophen-3-yl)(4-(2-(piperidin-1yl)ethoxy)phenyl)methanone 2,2,2-trifluoroacetate $(4.98 \mathrm{mg}, 1.7 \%)$

${ }^{1} \mathrm{H}$ NMR $\left(400 \mathrm{MHz}\right.$, Methanol- $\left.d_{4}\right) \delta 7.76(\mathrm{~d}, J=8.9 \mathrm{~Hz}, 2 \mathrm{H}), 7.42(\mathrm{dd}, J=8.8,0.5 \mathrm{~Hz}, 1 \mathrm{H}), 7.32$ $-7.26(\mathrm{~m}, 3 \mathrm{H}), 6.93(\mathrm{~d}, J=8.9 \mathrm{~Hz}, 2 \mathrm{H}), 6.88(\mathrm{dd}, J=8.8,2.3 \mathrm{~Hz}, 1 \mathrm{H}), 6.78(\mathrm{~d}, J=8.8 \mathrm{~Hz}, 2 \mathrm{H})$, $4.40-4.32(\mathrm{~m}, 2 \mathrm{H}), 3.73(\mathrm{~s}, 3 \mathrm{H}), 3.62-3.55(\mathrm{~m}, 2 \mathrm{H}), 3.55-3.51(\mathrm{~m}, 2 \mathrm{H}), 3.04(\mathrm{t}, J=12.0 \mathrm{~Hz}$, $2 \mathrm{H}), 2.00-1.89(\mathrm{~m}, 2 \mathrm{H}), 1.87-1.71(\mathrm{~m}, 3 \mathrm{H}), 1.60-1.46(\mathrm{~m}, 1 \mathrm{H})$.

LCMS (ESI, +ve mode) expected $m / z$ for $\mathrm{C}_{29} \mathrm{H}_{30} \mathrm{NO}_{4} \mathrm{~S}[\mathrm{M}+\mathrm{H}]^{+} 488.19$, found 488.20

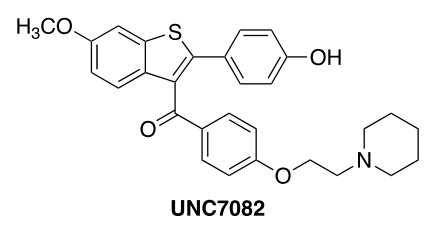

UNC7082: (2-(4-hydroxyphenyl)-6-methoxybenzo[b]thiophen-3-yl)(4-(2-(piperidin-1yl)ethoxy)phenyl)methanone 2,2,2-trifluoroacetate $(6.21 \mathrm{mg}, 2.1 \%)$

${ }^{1} \mathrm{H}$ NMR $\left(400 \mathrm{MHz}\right.$, Methanol- $\left.d_{4}\right) \delta 7.74(\mathrm{~d}, J=8.9 \mathrm{~Hz}, 2 \mathrm{H}), 7.51(\mathrm{~d}, J=8.9 \mathrm{~Hz}, 1 \mathrm{H}), 7.47(\mathrm{~d}, J=$ $2.3 \mathrm{~Hz}, 1 \mathrm{H}), 7.19(\mathrm{~d}, J=8.7 \mathrm{~Hz}, 2 \mathrm{H}), 6.99(\mathrm{dd}, J=8.9,2.4 \mathrm{~Hz}, 1 \mathrm{H}), 6.92(\mathrm{~d}, J=8.9 \mathrm{~Hz}, 2 \mathrm{H})$, $6.62(\mathrm{~d}, J=8.6 \mathrm{~Hz}, 2 \mathrm{H}), 4.40-4.32(\mathrm{~m}, 2 \mathrm{H}), 3.88(\mathrm{~s}, 3 \mathrm{H}), 3.62-3.55(\mathrm{~m}, 2 \mathrm{H}), 3.55-3.50(\mathrm{~m}$, $2 \mathrm{H}), 3.04(\mathrm{~d}, J=12.3 \mathrm{~Hz}, 2 \mathrm{H}), 2.00-1.88(\mathrm{~m}, 2 \mathrm{H}), 1.87-1.70(\mathrm{~m}, 3 \mathrm{H}), 1.60-1.44(\mathrm{~m}, 1 \mathrm{H})$.

LCMS (ESI, +ve mode) expected $m / z$ for $\mathrm{C}_{29} \mathrm{H}_{30} \mathrm{NO}_{4} \mathrm{~S}[\mathrm{M}+\mathrm{H}]^{+} 488.19$, found 488.15 


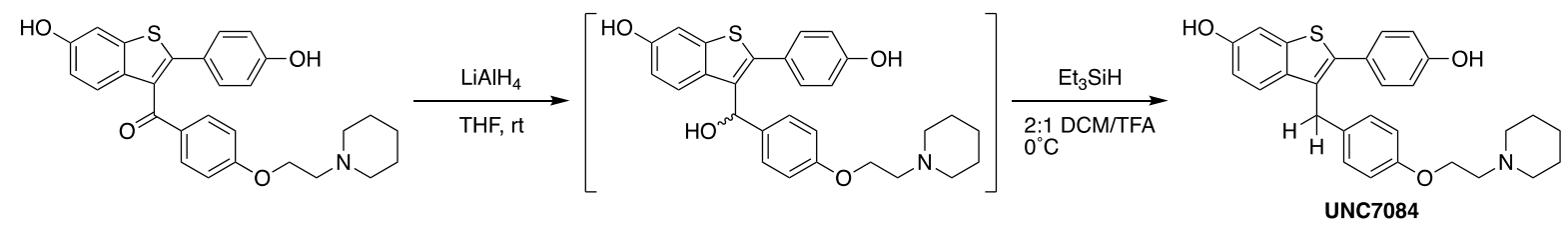

To a flask containing commercial raloxifene hydrochloride (250 mg, $1 \mathrm{Eq}, 490 \mu \mathrm{mol})$ was added anhydrous THF (10 mL) under nitrogen atmosphere. The flask was stirred rapidly and cooled to $0{ }^{\circ} \mathrm{C}$ in an ice bath, and $\mathrm{LiAlH}_{4}(200 \mathrm{mg}, 10.8 \mathrm{Eq}, 5.27 \mathrm{mmol})$ was added cautiously (effervescence). The reaction mixture turned deep green and was allowed to come to room temperature overnight. The next day, residual $\mathrm{LiAlH}_{4}$ was quenched by addition of ethyl acetate to the grey-green slurry. The mixture was diluted with half-saturated Rochelle salt and stirred at room temperature for an hour. The layers were separated, and the aqueous layer extracted twice more with ethyl acetate. The combined organic layers were washed once with halfsaturated Rochelle salt, once with water, and once with brine, then dried over sodium sulfate and concentrated to a yellow solid ( $234 \mathrm{mg}$, quantitative). Attempted salt formation with TFA, $p$ toluenesulfonic acid, or $\mathrm{HCl}$ in ether, ethyl acetate, or 1,4-dioxane led only to decomposition, so the remaining residue was used without further purification.

To a flask containing crude 3-(hydroxy(4-(2-(piperidin-1-yl)ethoxy)phenyl)methyl)-2-(4hydroxyphenyl)benzo[b]thiophen-6-ol (50 mg, $1 \mathrm{Eq}, 0.11 \mathrm{mmol})$ was added DCM $(2 \mathrm{~mL})$ and triethylsilane (15 mg, $20 \mu \mathrm{L}, 1.2 \mathrm{Eq}, 0.13 \mathrm{mmol}$ ) and cooled in an ice-water bath under nitrogen atmosphere. To the stirring solution was added TFA $(1.0 \mathrm{~mL})$ dropwise - formation of the benzylic cation was characterized by a blue colour, which rapidly disappeared upon silane reduction. Upon reaction completion as indicated by LCMS, the solvents were removed in vacuo and the residue purified by reverse-phase chromatography $(10-100 \%$ methanol in water $+0.1 \%$ TFA), concentrated, and lyophilized to yield 2-(4-hydroxyphenyl)-3-(4-(2-(piperidin-1yl)ethoxy)benzyl)benzo[b]thiophen-6-ol 2,2,2-trifluoroacetate (55 mg, 91\% over two steps) as a white solid.

${ }^{1} \mathrm{H}$ NMR (400 MHz, Methanol- $\left.d_{4}\right) \delta 7.28(\mathrm{dd}, J=8.7,2.1 \mathrm{~Hz}, 3 \mathrm{H}), 7.18(\mathrm{~d}, J=2.2 \mathrm{~Hz}, 1 \mathrm{H}), 7.06$ $(\mathrm{d}, J=8.6 \mathrm{~Hz}, 2 \mathrm{H}), 6.87(\mathrm{~d}, J=8.7 \mathrm{~Hz}, 2 \mathrm{H}), 6.79(\mathrm{~d}, J=8.3 \mathrm{~Hz}, 2 \mathrm{H}), 6.75(\mathrm{dd}, J=8.7,2.3 \mathrm{~Hz}$, $1 \mathrm{H}), 4.28(\mathrm{dd}, J=5.6,4.3 \mathrm{~Hz}, 2 \mathrm{H}), 4.12(\mathrm{~s}, 2 \mathrm{H}), 3.62-3.54(\mathrm{~m}, 2 \mathrm{H}), 3.53-3.46(\mathrm{~m}, 2 \mathrm{H}), 3.02$ $(\mathrm{td}, J=12.3,3.2 \mathrm{~Hz}, 2 \mathrm{H}), 1.98-1.88(\mathrm{~m}, 2 \mathrm{H}), 1.86-1.71(\mathrm{~m}, 3 \mathrm{H}), 1.59-1.44(\mathrm{~m}, 1 \mathrm{H})$.

LCMS (ESI, +ve mode) expected $m / z$ for $\mathrm{C}_{28} \mathrm{H}_{30} \mathrm{NO}_{3} \mathrm{~S}[\mathrm{M}+\mathrm{H}]^{+} 460.19$, found 460.15

HRMS (ESI, +ve mode) expected $m / z$ for $\mathrm{C}_{28} \mathrm{H}_{30} \mathrm{NO}_{3} \mathrm{~S}[\mathrm{M}+\mathrm{H}]^{+} 460.19409$, found 460.19323

\section{UNC7266}



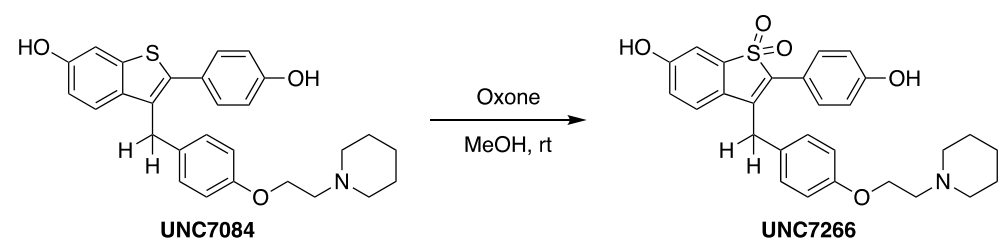

To a glass vial was added 2-(4-hydroxyphenyl)-3-(4-(2-(piperidin-1yl)ethoxy)benzyl)benzo[b]thiophen-6-ol 2,2,2-trifluoroacetate (UNC7084, $5.0 \mathrm{mg}, 1 \mathrm{Eq}, 8.7$ $\mu \mathrm{mol})$ and methanol $(0.1 \mathrm{~mL})$. The methanol was stirred, and Oxone ${ }^{\mathrm{TM}}(16 \mathrm{mg}, 3 \mathrm{Eq}, 26$ $\mu \mathrm{mol})$ dissolved in water $(0.1 \mathrm{~mL})$ was added. The reaction was stirred at room temperature until LCMS indicated complete conversion, whereupon the reaction was quenched by the addition of a few drops of aqueous sodium bisulfite. The crude reaction mixture was purified by reverse phase chromatography $(10-100 \%$ acetonitrile in water $+0.1 \%$ TFA), concentrated, and lyophilized to yield 6-hydroxy-2-(4-hydroxyphenyl)-3-(4-(2-(piperidin-1yl)ethoxy)benzyl)benzo[b]thiophene 1,1-dioxide 2,2,2-trifluoroacetate ( $4.79 \mathrm{mg}, 91 \%)$ as a yellow solid.

${ }^{1} \mathrm{H}$ NMR $\left(400 \mathrm{MHz}\right.$, Methanol- $\left.d_{4}\right) \delta 7.41(\mathrm{~d}, J=8.7 \mathrm{~Hz}, 2 \mathrm{H}), 7.17(\mathrm{~d}, J=5.1 \mathrm{~Hz}, 1 \mathrm{H}), 7.15(\mathrm{~d}, J=$ $5.4 \mathrm{~Hz}, 2 \mathrm{H}), 7.10(\mathrm{~d}, J=2.3 \mathrm{~Hz}, 1 \mathrm{H}), 6.93(\mathrm{~d}, J=8.7 \mathrm{~Hz}, 2 \mathrm{H}), 6.88-6.83(\mathrm{~m}, 3 \mathrm{H}), 4.33-4.25$ $(\mathrm{m}, 2 \mathrm{H}), 3.96(\mathrm{~s}, 2 \mathrm{H}), 3.63-3.54(\mathrm{~m}, 2 \mathrm{H}), 3.54-3.47(\mathrm{~m}, 2 \mathrm{H}), 3.02(\mathrm{td}, J=12.3,3.1 \mathrm{~Hz}, 2 \mathrm{H})$, $1.99-1.67(\mathrm{~m}, 5 \mathrm{H}), 1.59-1.44(\mathrm{~m}, 1 \mathrm{H})$.

LCMS (ESI, +ve mode) expected $m / z$ for $\mathrm{C}_{28} \mathrm{H}_{30} \mathrm{NO}_{5} \mathrm{~S}[\mathrm{M}+\mathrm{H}]^{+} 492.18$, found 492.20

General Synthetic Procedures for Raloxifene Analogs Prepared from 6-methoxy-2-(4methoxyphenyl)benzo[b]thiophene

With the exception of UNC7088 (made by demethylation of 6-methoxy-2-(4methoxyphenyl)benzo[b]thiophene) and UNC7152 (made by demethylation of UNC7086), the remaining compounds were synthesized according to the following scheme:

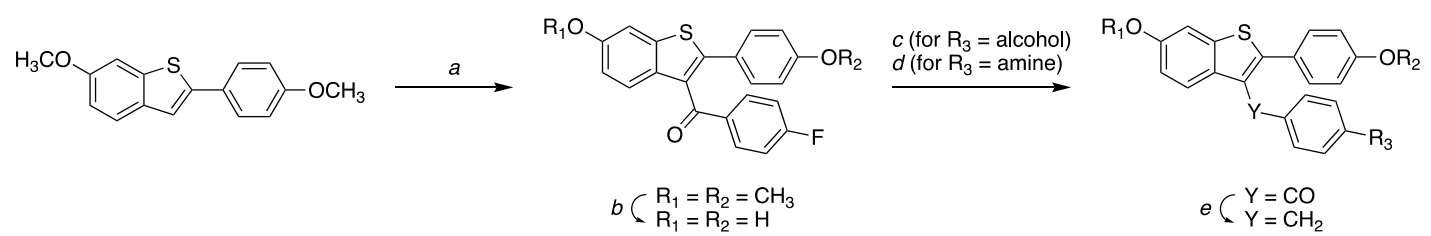

a) 4-fluorobenzoyl chloride, $\mathrm{AlCl}_{3}$ b) pyridine hydrochloride, $180^{\circ} \mathrm{C}$ c) $\mathrm{NaH}, \mathrm{DMF}$ d) neat or DMSO, $100^{\circ} \mathrm{C}$ e) i. $\mathrm{LiAlH}_{4}$, THF ii. Et ${ }_{3} \mathrm{SiH}, 2: 1 \mathrm{DCM} / \mathrm{TFA}$

General Procedure A: Friedel-Crafts acylation 
To a flask was added 6-methoxy-2-(4-methoxyphenyl)benzo[b]thiophene and anhydrous DCM. The reaction was cooled to $0^{\circ} \mathrm{C}$, and 4-fluorobenzoyl chloride $(1.1 \mathrm{Eq})$ was added dropwise, followed by granular anhydrous $\mathrm{AlCl}_{3}(1.2 \mathrm{Eq})$. The reaction was stirred at room temperature overnight, then quenched with $2 \mathrm{M} \mathrm{HCl}$. The aqueous layer was extracted thrice with $\mathrm{DCM}$, and the combined organic layers were further washed with a 50/50 mixture of $2 \mathrm{M} \mathrm{HCl}$ and brine, then brine alone, dried over sodium sulfate, concentrated and purified by normal phase chromatography over silica gel.

\section{General Procedure B: Aryl ether demethylation}

The aryl ether starting material was added to a glass vial with $0.2-1.0 \mathrm{~g}$ of pyridine hydrochloride and heated to $180^{\circ} \mathrm{C}$ for 2 hours. Dilution with water or sodium bicarbonate followed by extraction with ethyl acetate and chromatography yielded the free phenol.

\section{General Procedure C: Nucleophilic aromatic substitution with alcohols}

The appropriate alcohol (5 Eq) was dissolved in anhydrous DMF and cooled to $0^{\circ} \mathrm{C}$, followed by addition of excess $60 \%$ sodium hydride (8-12 Eq). The solution was brought to room temperature over 30 minutes, and the fluoroketone substrate $(1 \mathrm{Eq})$ was then added. The reaction was then stirred for 5 hours at room temperature $\left(R_{1}=C_{3}\right)$ or $50^{\circ} \mathrm{C}\left(R_{1}=H\right)$. The reaction was quenched with water, optionally extracted with ethyl acetate, and subjected to reverse-phase chromatography (methanol in water $+0.1 \%$ TFA).

\section{General Procedure D: Nucleophilic aromatic substitution with amines}

The fluoroketone substrate and excess amine were added to a glass vial. If the amine was a solid, DMSO was added as solvent, otherwise the reaction was conducted neat. The vial was heated to $100-120^{\circ} \mathrm{C}$ for 5 hours, cooled, diluted with water and purified by reverse-phase chromatography (methanol in water $+0.1 \%$ TFA).

\section{General Procedure E: Ketone reduction with $\mathrm{LiAlH}_{4}$ and ionic reduction with TFA/Et $3 \mathrm{SiH}$}

To a glass vial were added the ketone substrate and THF. The vial was cooled to $0^{\circ} \mathrm{C}$ and excess $\mathrm{LiAlH}_{4}$ (10-40 eq) was added. The reaction was stirred at room temperature until complete consumption of starting material as determined by LC/MS, then quenched by the addition of saturated sodium bicarbonate. The mixture was partitioned between ethyl acetate and $0.5 \mathrm{M}$ potassium sodium tartrate, washed again with tartrate solution, dried by passage through a phase separator and concentrated to a yellowish residue that was used without further purification.

To a glass vial was added the crude alcohol, DCM, and triethylsilane (1.3 eq). The vial was cooled to $0^{\circ} \mathrm{C}$, and TFA was added dropwise to a final ratio of 2:1 DCM/TFA. The reaction was stirred until complete conversion as determined visually (the intermediate cation before 
reduction is a vivid blue color) and by LCMS. The solvents were removed by rotavap and the residue purified by reverse-phase chromatography (methanol in water $+0.1 \%$ TFA).

\section{$\underline{\text { UNC7088 }}$}

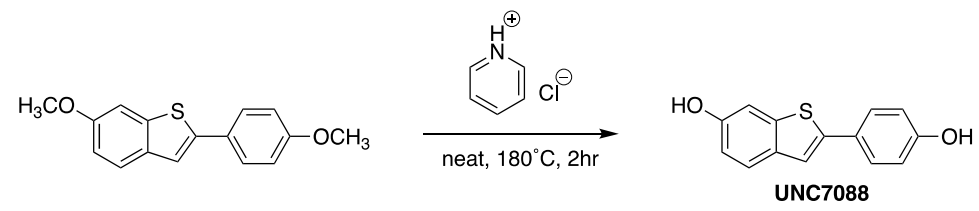

To a glass vial was added 6-methoxy-2-(4-methoxyphenyl)benzo[b]thiophene $(27 \mathrm{mg}, 1 \mathrm{Eq}$, $0.10 \mathrm{mmol})$ and pyridine hydrochloride $(0.12 \mathrm{~g}, 10 \mathrm{Eq}, 1.0 \mathrm{mmol})$. The vial was then heated to $180^{\circ} \mathrm{C}$ for 2 hours. The first 30 minutes were accompanied by vigorous bubbling and steam evolution starting at $\sim 140^{\circ} \mathrm{C}$. The reaction was cooled, diluted with water, and extracted thrice with ethyl acetate. The combined organic layers were washed twice with $0.5 \mathrm{M}$ citric acid, once with water, and once with brine, then dried over sodium sulfate, filtered, and concentrated to an off-white solid. Normal phase chromatography over silica gel $(0-50 \%$ ethyl acetate in hexanes) yielded 2-(4-hydroxyphenyl)benzo[ $b$ ]thiophen-6-ol (15.5 mg, 64\%) as an off-white solid .

${ }^{1} \mathrm{H}$ NMR $\left(400 \mathrm{MHz}\right.$, Acetone- $\left.d_{6}\right) \delta 7.59(\mathrm{~d}, J=8.5 \mathrm{~Hz}, 1 \mathrm{H}), 7.54(\mathrm{~d}, J=8.7 \mathrm{~Hz}, 2 \mathrm{H}), 7.42(\mathrm{~d}, J=$ $0.7 \mathrm{~Hz}, 1 \mathrm{H}), 7.28$ (dt, $J=2.3,0.7 \mathrm{~Hz}, 1 \mathrm{H}), 6.90(\mathrm{~d}, J=8.8 \mathrm{~Hz}, 3 \mathrm{H})$.

LCMS (ESI, +ve mode) expected $m / z$ for $\mathrm{C}_{14} \mathrm{H}_{10} \mathrm{NaO}_{2} \mathrm{~S}[\mathrm{M}+\mathrm{Na}]^{+} 265.03$, found 265.30

HRMS (ESI, -ve mode) expected $m / z$ for $\mathrm{C}_{14} \mathrm{H}_{9} \mathrm{O}_{2} \mathrm{~S}[\mathrm{M}-\mathrm{H}]^{-} 241.03287$, found 241.03273

\section{$\underline{\text { Key Intermediate I }}$}

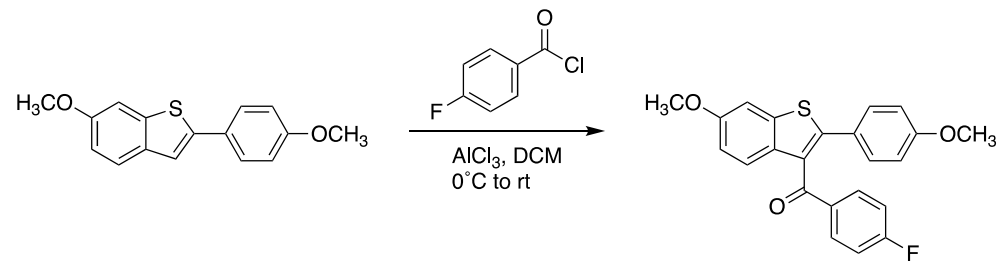

To a flask was added 6-methoxy-2-(4-methoxyphenyl)benzo[b]thiophene $(0.54 \mathrm{~g}, 1 \mathrm{Eq}, 2.0$ $\mathrm{mmol})$, DCM $(20 \mathrm{~mL})$, and 4-fluorobenzoyl chloride $(0.35 \mathrm{~g}, 0.26 \mathrm{~mL}, 1.1 \mathrm{Eq}, 2.2 \mathrm{mmol})$ under nitrogen atmosphere. The flask was cooled in an ice-water bath, and aluminum chloride $(0.32 \mathrm{~g}$, $1.2 \mathrm{Eq}, 2.4 \mathrm{mmol}$ ) was added portionwise, with the solution turning a deep blood red. The reaction was allowed to come to room temperature with stirring overnight. The next day, the 
reaction was quenched with the addition of $2 \mathrm{M} \mathrm{HCl}$ and extracted three times with $\mathrm{DCM}$. The combined organic layers were washed once with a 50/50 mixture of $2 \mathrm{M} \mathrm{HCl}$ and brine, once with water, and once with brine, then dried over sodium sulfate, filtered, and concentrated to an orange oil. Normal phase chromatography over silica gel (0-30\% ethyl acetate in hexanes) provided (4-fluorophenyl)(6-methoxy-2-(4-methoxyphenyl)benzo[b]thiophen-3-yl)methanone (591 $\mathrm{mg}, 75 \%)$ as a clear yellow gum.

${ }^{1} \mathrm{H}$ NMR (400 MHz, Chloroform- $d$ ) $\delta 7.79$ (dd, $\left.J=8.9,5.4 \mathrm{~Hz}, 2 \mathrm{H}\right), 7.63(\mathrm{~d}, J=8.9 \mathrm{~Hz}, 1 \mathrm{H}), 7.33$ (d, $J=2.4 \mathrm{~Hz}, 1 \mathrm{H}$ ), $7.30(\mathrm{~d}, J=8.8 \mathrm{~Hz}, 2 \mathrm{H}), 7.00$ (dd, $J=8.9,2.4 \mathrm{~Hz}, 1 \mathrm{H}), 6.93$ (t, $J=8.6 \mathrm{~Hz}$, $2 \mathrm{H}), 6.74(\mathrm{~d}, J=8.8 \mathrm{~Hz}, 2 \mathrm{H}), 3.89(\mathrm{~s}, 3 \mathrm{H}), 3.74(\mathrm{~s}, 3 \mathrm{H})$.

${ }^{19}$ F NMR (376 MHz, Chloroform- $d$ ) $\delta-104.80$.

${ }^{13} \mathrm{C}$ NMR $(100 \mathrm{MHz}$, Chloroform- $d) \delta 192.75,165.64\left(\mathrm{~d}, J_{C F}=255.4 \mathrm{~Hz}\right), 159.93,157.78$, 144.23, 140.11, $133.92\left(\mathrm{~d}, J_{C F}=2.9 \mathrm{~Hz}\right), 133.71,132.51\left(\mathrm{~d}, J_{C F}=9.5 \mathrm{~Hz}\right), 130.47,129.87$, 125.77, 124.10, 115.44 (d, J JF $=22.0 \mathrm{~Hz}), 114.99,114.05,104.50,55.63,55.25$.

\section{$\underline{\text { UNC7083 }}$}
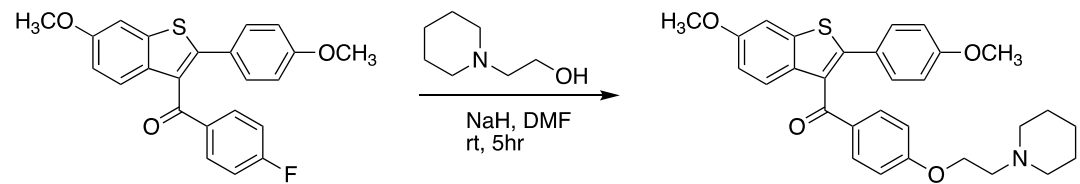

UNC7083

To a round bottom flask was added 2-(piperidin-1-yl)ethan-1-ol (33 mg, $5 \mathrm{Eq}, 0.25 \mathrm{mmol}$ ) and anhydrous DMF $(0.5 \mathrm{~mL})$. The flask was cooled in an ice-water bath, and sodium hydride $(60 \%$ dispersion in mineral oil, $20 \mathrm{mg}, 10 \mathrm{Eq}, 0.51 \mathrm{mmol}$ ) was slowly added. The reaction was allowed to come to room temperature with stirring over 30 minutes. Next, (4-fluorophenyl)(6-methoxy-2(4-methoxyphenyl)benzo[b]thiophen-3-yl)methanone (20 mg, $1 \mathrm{Eq}, 51 \mu \mathrm{mol}$ ) was dissolved in DMF $(0.5 \mathrm{~mL})$ and added dropwise to the flask. The reaction was allowed to proceed at room temperature for 4 hours, and then quenched by the addition of water. The aqueous layer was extracted 3 times with ethyl acetate, and the combined organic layers were washed twice with water, once with saturated sodium bicarbonate, and once with brine, and then dried by passage through a phase separator and concentrated to a yellow residue. Purification by reverse-phase chromatography (10-100\% methanol in water + 0.1\% TFA) provided (6-methoxy-2-(4methoxyphenyl)benzo[b]thiophen-3-yl)(4-(2-(piperidin-1-yl)ethoxy)phenyl)methanone 2,2,2trifluoroacetate $(22.40 \mathrm{mg}, 71 \%)$ as a yellow solid following lyophilization. 
${ }^{1} \mathrm{H}$ NMR $\left(400 \mathrm{MHz}\right.$, Methanol- $\left.d_{4}\right) \delta 7.74(\mathrm{~d}, J=8.9 \mathrm{~Hz}, 2 \mathrm{H}), 7.47(\mathrm{~d}, J=6.8 \mathrm{~Hz}, 1 \mathrm{H}), 7.46(\mathrm{~s}$, $1 \mathrm{H}), 7.29(\mathrm{~d}, J=8.8 \mathrm{~Hz}, 2 \mathrm{H}), 6.97(\mathrm{dd}, J=8.8,2.5 \mathrm{~Hz}, 1 \mathrm{H}), 6.91(\mathrm{~d}, J=8.9 \mathrm{~Hz}, 2 \mathrm{H}), 6.77(\mathrm{~d}, J=$ $8.8 \mathrm{~Hz}, 2 \mathrm{H}), 4.39-4.29(\mathrm{~m}, 2 \mathrm{H}), 3.87(\mathrm{~s}, 3 \mathrm{H}), 3.72(\mathrm{~s}, 3 \mathrm{H}), 3.61-3.54(\mathrm{~m}, 2 \mathrm{H}), 3.54-3.50(\mathrm{~m}$, $2 \mathrm{H}), 3.02(\mathrm{td}, J=12.3,3.1 \mathrm{~Hz}, 2 \mathrm{H}), 1.98-1.72(\mathrm{~m}, 5 \mathrm{H}), 1.58-1.43(\mathrm{~m}, 1 \mathrm{H})$.

LCMS (ESI, +ve mode) expected $m / z$ for $\mathrm{C}_{30} \mathrm{H}_{32} \mathrm{NO}_{4} \mathrm{~S}[\mathrm{M}+\mathrm{H}]^{+} 502.20$, found 502.20

\section{$\underline{\text { UNC7085 }}$}

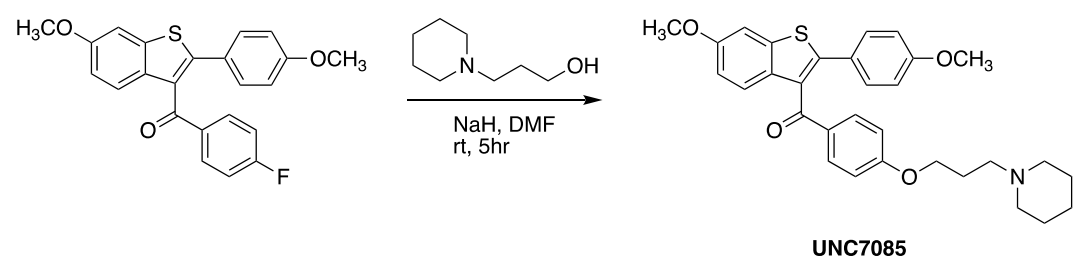

To a glass vial with septum was added 3-(piperidin-1-yl)propan-1-ol (18 mg, $19 \mu \mathrm{L}, 2 \mathrm{Eq}, 0.13$ $\mathrm{mmol}$ ) and anhydrous DMF (0.5 mL). Then sodium hydride $(5.6 \mathrm{mg}, 2.2 \mathrm{Eq}, 0.14 \mathrm{mmol})$ was added portionwise, and allowed to stir for 30 minutes. To the vial was then added (4fluorophenyl)(6-methoxy-2-(4-methoxyphenyl)benzo[b]thiophen-3-yl)methanone (25 mg, $1 \mathrm{Eq}$, $64 \mu \mathrm{mol})$. The reaction turns deep blood-red and was allowed to stir at room temperature overnight. The reaction was then quenched with saturated sodium bicarbonate and extracted thrice with ethyl acetate. The combined organic layers were washed three times with saturated sodium bicarbonate and once with brine, then dried over sodium sulfate, filtered, and concentrated to a yellow residue. The residue was purified by reverse-phase chromatography $(10-100 \%$ methanol in water $+0.1 \%$ TFA $)$, and the collected fractions were concentrated and lyophilized to yield (6-methoxy-2-(4-methoxyphenyl)benzo[b]thiophen-3-yl)(4-(3-(piperidin-1yl)propoxy)phenyl)methanone 2,2,2-trifluoroacetate $(16.5 \mathrm{mg}, 41 \%)$ as an off yellow solid.

${ }^{1} \mathrm{H}$ NMR $\left(400 \mathrm{MHz}\right.$, Methanol- $\left.d_{4}\right) \delta 7.71(\mathrm{~d}, J=8.9 \mathrm{~Hz}, 2 \mathrm{H}), 7.45(\mathrm{~d}, J=1.1 \mathrm{~Hz}, 1 \mathrm{H}), 7.44(\mathrm{~d}, J=$ $5.1 \mathrm{~Hz}, 1 \mathrm{H}), 7.28(\mathrm{~d}, J=8.8 \mathrm{~Hz}, 2 \mathrm{H}), 6.96(\mathrm{dd}, J=9.0,2.4 \mathrm{~Hz}, 1 \mathrm{H}), 6.82(\mathrm{~d}, J=8.9 \mathrm{~Hz}, 2 \mathrm{H})$, $6.76(\mathrm{~d}, J=8.8 \mathrm{~Hz}, 2 \mathrm{H}), 4.06(\mathrm{t}, J=5.8 \mathrm{~Hz}, 2 \mathrm{H}), 3.86(\mathrm{~s}, 3 \mathrm{H}), 3.71(\mathrm{~s}, 3 \mathrm{H}), 3.58-3.50(\mathrm{~m}, 2 \mathrm{H})$, $3.27-3.18(\mathrm{~m}, 2 \mathrm{H}), 2.90(\mathrm{td}, J=12.4,2.9 \mathrm{~Hz}, 2 \mathrm{H}), 2.23-2.12(\mathrm{~m}, 2 \mathrm{H}), 1.98-1.88(\mathrm{~m}, 2 \mathrm{H})$, $1.87-1.66(\mathrm{~m}, 3 \mathrm{H}), 1.50$ (ddt, $J=16.2,12.4,6.4 \mathrm{~Hz}, 1 \mathrm{H})$.

LCMS (ESI, +ve mode) expected $m / z$ for $\mathrm{C}_{31} \mathrm{H}_{34} \mathrm{NO}_{4} \mathrm{~S}[\mathrm{M}+\mathrm{H}]^{+} 516.22$, found 516.20

\section{$\underline{\text { UNC7086 }}$}



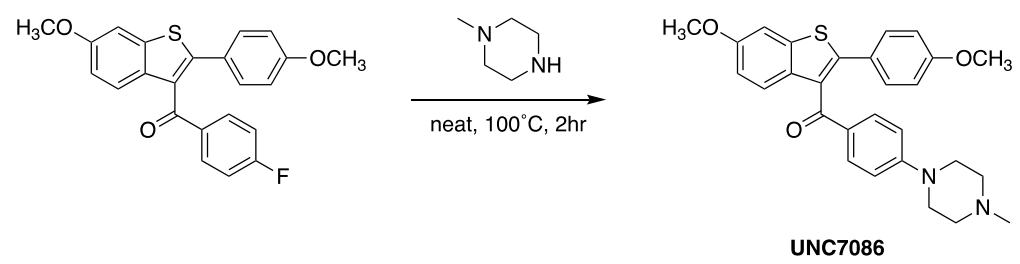

To a glass vial was added (4-fluorophenyl)(6-methoxy-2-(4-methoxyphenyl)benzo[b]thiophen-3$\mathrm{yl})$ methanone $(25 \mathrm{mg}, 1 \mathrm{Eq}, 64 \mu \mathrm{mol})$ and 1-methylpiperazine $(64 \mathrm{mg}, 71 \mu \mathrm{L}, 10 \mathrm{Eq}, 0.64$ $\mathrm{mmol})$. The vial was heated to $100^{\circ} \mathrm{C}$ for 5 hours, then cooled, diluted with water, and purified by reverse-phase chromatography (10-100\% methanol in water $+0.1 \%$ TFA). The collected fractions were concentrated and lyophilized to provide (6-methoxy-2-(4-

methoxyphenyl)benzo[b]thiophen-3-yl)(4-(4-methylpiperazin-1-yl)phenyl)methanone 2,2,2trifluoroacetate $(15.2 \mathrm{mg}, 41 \%)$ as a yellow solid.

${ }^{1} \mathrm{H}$ NMR $\left(400 \mathrm{MHz}\right.$, Methanol- $\left.d_{4}\right) \delta 7.66(\mathrm{~d}, J=9.0 \mathrm{~Hz}, 2 \mathrm{H}), 7.43(\mathrm{~d}, J=2.3 \mathrm{~Hz}, 1 \mathrm{H}), 7.40(\mathrm{~d}, J=$ $8.9 \mathrm{~Hz}, 1 \mathrm{H}), 7.29(\mathrm{~d}, J=8.8 \mathrm{~Hz}, 2 \mathrm{H}), 6.94(\mathrm{dd}, J=8.9,2.4 \mathrm{~Hz}, 1 \mathrm{H}), 6.84(\mathrm{~d}, J=9.0 \mathrm{~Hz}, 2 \mathrm{H})$, $6.75(\mathrm{~d}, J=8.8 \mathrm{~Hz}, 2 \mathrm{H}), 4.07-3.92(\mathrm{~m}, 2 \mathrm{H}), 3.85(\mathrm{~s}, 3 \mathrm{H}), 3.70(\mathrm{~s}, 3 \mathrm{H}), 3.60-3.46(\mathrm{~m}, 2 \mathrm{H})$, $3.20-3.06(\mathrm{~m}, 4 \mathrm{H}), 2.91(\mathrm{~s}, 3 \mathrm{H})$.

LCMS (ESI, +ve mode) expected $m / z$ for $\mathrm{C}_{28} \mathrm{H}_{29} \mathrm{~N}_{2} \mathrm{O}_{3} \mathrm{~S}[\mathrm{M}+\mathrm{H}]^{+} 473.19$, found 473.20

\section{$\underline{\text { UNC7087 }}$}
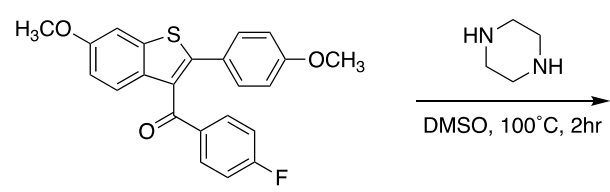

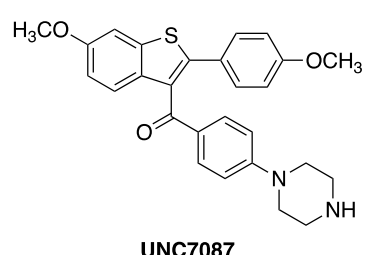

UNC7087

To a glass vial was added (4-fluorophenyl)(6-methoxy-2-(4-methoxyphenyl)benzo[ $b]$ thiophen-3$\mathrm{yl}$ )methanone (25 mg, $1 \mathrm{Eq}, 64 \mu \mathrm{mol})$, piperazine (55 mg, $10 \mathrm{Eq}, 0.64 \mathrm{mmol})$, and DMSO $(0.2$ $\mathrm{mL}$ ). The vial was capped and heated to $100^{\circ} \mathrm{C}$ for 5 hours, then cooled, diluted with water, and purified by reverse-phase chromatography (10-100\% methanol in water $+0.1 \%$ TFA). The collected fractions were concentrated and lyophilized to yield (6-methoxy-2-(4methoxyphenyl)benzo[b]thiophen-3-yl)(4-(piperazin-1-yl)phenyl)methanone 2,2,2trifluoroacetate (15.4 $\mathrm{mg}, 42 \%)$ as a yellow solid.

${ }^{1} \mathrm{H}$ NMR (400 MHz, Methanol- $\left.d_{4}\right) \delta 7.66(\mathrm{~d}, J=9.0 \mathrm{~Hz}, 2 \mathrm{H}), 7.43(\mathrm{~d}, J=2.3 \mathrm{~Hz}, 1 \mathrm{H}), 7.40$ (dd, J $=8.9,0.5 \mathrm{~Hz}, 1 \mathrm{H}), 7.29(\mathrm{~d}, J=8.8 \mathrm{~Hz}, 2 \mathrm{H}), 6.94(\mathrm{dd}, J=8.9,2.4 \mathrm{~Hz}, 1 \mathrm{H}), 6.84(\mathrm{~d}, J=9.1 \mathrm{~Hz}$, $2 \mathrm{H}), 6.75(\mathrm{~d}, J=8.8 \mathrm{~Hz}, 2 \mathrm{H}), 3.85(\mathrm{~s}, 3 \mathrm{H}), 3.70(\mathrm{~s}, 3 \mathrm{H}), 3.55-3.49(\mathrm{~m}, 4 \mathrm{H}), 3.30-3.25(\mathrm{~m}$, $4 \mathrm{H})$.

LCMS (ESI, +ve mode) expected $m / z$ for $\mathrm{C}_{27} \mathrm{H}_{27} \mathrm{~N}_{2} \mathrm{O}_{3} \mathrm{~S}[\mathrm{M}+\mathrm{H}]^{+} 459.17$, found 459.20

HRMS (ESI, +ve mode) expected $m / z$ for $\mathrm{C}_{27} \mathrm{H}_{27} \mathrm{~N}_{2} \mathrm{O}_{3} \mathrm{~S}[\mathrm{M}+\mathrm{H}]^{+} 459.17369$, found 459.17285 


\section{UNC7152}

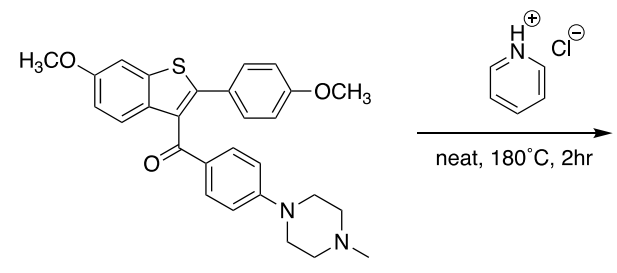

UNC7086

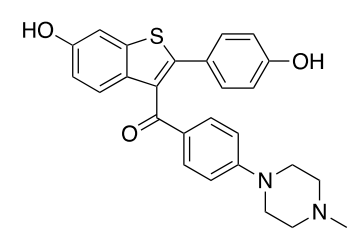

UNC7152

To a glass vial was added (6-methoxy-2-(4-methoxyphenyl)benzo[ $b]$ thiophen-3-yl)(4-(4methylpiperazin-1-yl)phenyl)methanone $(8.0 \mathrm{mg}, 1 \mathrm{Eq}, 17 \mu \mathrm{mol})$ and pyridine hydrochloride (200 mg, $100 \mathrm{Eq}, 1.73 \mathrm{mmol}$ ). The vial was then heated to $180^{\circ} \mathrm{C}$ for 2 hours. The reaction was cooled, diluted with sodium bicarbonate, and extracted thrice with ethyl acetate. The combined organic layers were washed once more with sodium bicarbonate, twice with water, and once with brine, then dried over sodium sulfate, filtered, and concentrated to an off-white solid. Reverse phase chromatography (10-100\% methanol in water $+0.1 \%$ TFA) followed by concentration and lyophilization yielded (6-hydroxy-2-(4-hydroxyphenyl)benzo[ $b$ ]thiophen-3yl)(4-(4-methylpiperazin-1-yl)phenyl)methanone 2,2,2-trifluoroacetate $(3.75 \mathrm{mg}, 40 \%)$ as a yellow solid.

${ }^{1} \mathrm{H}$ NMR $\left(400 \mathrm{MHz}\right.$, Methanol- $\left.d_{4}\right) \delta 7.69(\mathrm{~d}, J=9.0 \mathrm{~Hz}, 2 \mathrm{H}), 7.37(\mathrm{~d}, J=8.8 \mathrm{~Hz}, 1 \mathrm{H}), 7.25(\mathrm{~d}, J=$ $2.2 \mathrm{~Hz}, 1 \mathrm{H}), 7.20(\mathrm{~d}, J=8.7 \mathrm{~Hz}, 2 \mathrm{H}), 6.89(\mathrm{~d}, J=9.1 \mathrm{~Hz}, 2 \mathrm{H}), 6.85(\mathrm{dd}, J=8.8,2.3 \mathrm{~Hz}, 1 \mathrm{H})$, $6.62(\mathrm{~d}, J=8.6 \mathrm{~Hz}, 2 \mathrm{H}), 4.17-3.90(\mathrm{~m}, 2 \mathrm{H}), 3.62-3.36(\mathrm{~m}, 3 \mathrm{H}), 3.26-3.07(\mathrm{~m}, 3 \mathrm{H}), 2.93(\mathrm{~s}$, $3 \mathrm{H})$.

LCMS (ESI, +ve mode) expected $m / z$ for $\mathrm{C}_{26} \mathrm{H}_{25} \mathrm{~N}_{2} \mathrm{O}_{3} \mathrm{~S}[\mathrm{M}+\mathrm{H}]^{+} 445.16$, found 445.20

\section{Key Intermediate II}
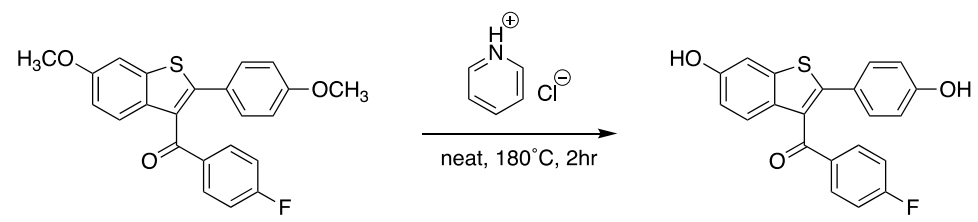

To a vial was added (4-fluorophenyl)(6-methoxy-2-(4-methoxyphenyl)benzo[b]thiophen-3$\mathrm{yl})$ methanone (100 mg, $1 \mathrm{Eq}, 255 \mu \mathrm{mol}$ ) and pyridine hydrochloride (589 mg, $20 \mathrm{Eq}, 5.10$ $\mathrm{mmol}$ ). The vial was loosely covered and heated to $180^{\circ} \mathrm{C}$ for a 2 hour period. After cooling, the residue was diluted with water and $2 \mathrm{M} \mathrm{HCl}$, and extracted 3 times with ethyl acetate. The combined organic layers were washed 3 times with $0.5 \mathrm{M}$ citric acid, once with water, and once with brine, then dried by passage through a phase separator and concentrated to an orange residue. Normal phase chromatography over silica gel (0-50\% ethyl acetate in hexanes) 
provided (4-fluorophenyl)(6-hydroxy-2-(4-hydroxyphenyl)benzo[b]thiophen-3-yl)methanone $(69.4 \mathrm{mg}, 74.7 \%)$ as an orange oil that solidified on standing.

${ }^{1} \mathrm{H}$ NMR (400 MHz, Acetone- $\left.d_{6}\right) \delta 7.79$ (dd, $\left.J=8.9,5.5 \mathrm{~Hz}, 2 \mathrm{H}\right), 7.55$ (dd, $\left.J=8.8,0.5 \mathrm{~Hz}, 1 \mathrm{H}\right)$, 7.41 (dd, $J=2.3,0.5 \mathrm{~Hz}, 1 \mathrm{H}$ ), $7.22(\mathrm{~d}, J=8.6 \mathrm{~Hz}, 2 \mathrm{H}$ ), 7.07 (t, $J=8.8 \mathrm{~Hz}, 2 \mathrm{H}$ ), 6.99 (dd, $J=8.8$, $2.3 \mathrm{~Hz}, 1 \mathrm{H}), 6.73(\mathrm{~d}, J=8.7 \mathrm{~Hz}, 2 \mathrm{H})$.

${ }^{19} \mathrm{~F}$ NMR (376 MHz, Acetone- $\left.d_{6}\right) \delta-107.08$.

${ }^{13} \mathrm{C}$ NMR (100 MHz, Acetone- $\left.d_{6}\right) \delta 192.98,166.27$ (d, $\left.J_{C F}=252.7 \mathrm{~Hz}\right), 158.83,156.41,144.28$, $140.86,135.21\left(\mathrm{~d}, J_{C F}=2.7 \mathrm{~Hz}\right), 133.79,133.25\left(\mathrm{~d}, J_{C F}=9.5 \mathrm{~Hz}\right), 131.28,130.51,125.52$, 124.76, 116.34, 116.24, $115.99\left(\mathrm{~d}, J_{C F}=4.6 \mathrm{~Hz}\right), 107.80$.

\section{$\underline{\text { UNC7153 }}$}

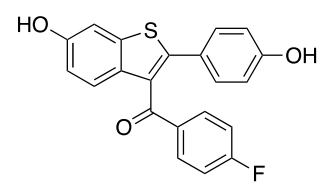

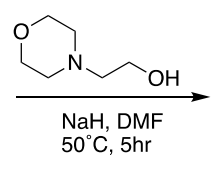

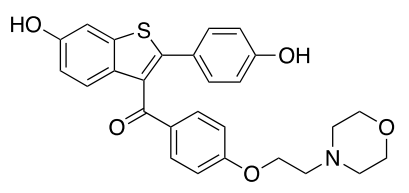

UNC7153

To a glass vial with septum was added 2-morpholinoethan-1-ol (16 mg, $5 \mathrm{Eq}, 0.12 \mathrm{mmol}$ ) and anhydrous DMF $(0.5 \mathrm{~mL})$. The vial was cooled in an ice-water bath and sodium hydride $(7.9 \mathrm{mg}$, $8 \mathrm{Eq}, 0.20 \mathrm{mmol}$ ) was added portionwise, then allowed to stir for 30 minutes while warming to room temperature. To the vial was then added (4-fluorophenyl)(6-hydroxy-2-(4hydroxyphenyl)benzo[b]thiophen-3-yl)methanone $(9.0 \mathrm{mg}, 1 \mathrm{Eq}, 25 \mu \mathrm{mol})$ (the reaction turns deep blood-red) and the reaction was heated to $50^{\circ} \mathrm{C}$ for 5 hours. The reaction was then cooled, quenched with water, acidified with TFA, and purified by reverse-phase chromatography $(10-100 \%$ methanol in water $+0.1 \%$ TFA). The collected fractions were concentrated and lyophilized to yield (6-hydroxy-2-(4-hydroxyphenyl)benzo[b]thiophen-3-yl)(4-(2morpholinoethoxy)phenyl)methanone $2,2,2$-trifluoroacetate $(7.00 \mathrm{mg}, 48 \%)$ as an off yellow solid.

${ }^{1} \mathrm{H}$ NMR $\left(400 \mathrm{MHz}\right.$, Methanol- $\left.d_{4}\right) \delta 7.74(\mathrm{~d}, J=8.8 \mathrm{~Hz}, 2 \mathrm{H}), 7.43(\mathrm{~d}, J=8.8 \mathrm{~Hz}, 1 \mathrm{H}), 7.26(\mathrm{~d}, J=$ $2.2 \mathrm{~Hz}, 1 \mathrm{H}), 7.17(\mathrm{~d}, J=8.6 \mathrm{~Hz}, 2 \mathrm{H}), 6.92(\mathrm{~d}, J=8.9 \mathrm{~Hz}, 2 \mathrm{H}), 6.87(\mathrm{dd}, J=8.8,2.3 \mathrm{~Hz}, 1 \mathrm{H})$, $6.60(\mathrm{~d}, J=8.6 \mathrm{~Hz}, 2 \mathrm{H}), 4.42-4.35(\mathrm{~m}, 2 \mathrm{H}), 4.13-3.91(\mathrm{~m}, 2 \mathrm{H}), 3.90-3.68(\mathrm{~m}, 2 \mathrm{H}), 3.64-$ $3.58(\mathrm{~m}, 2 \mathrm{H}), 3.58-3.46(\mathrm{~m}, 2 \mathrm{H}), 3.30-3.19(\mathrm{~m}, 2 \mathrm{H})$.

LCMS (ESI, +ve mode) expected $m / z$ for $\mathrm{C}_{27} \mathrm{H}_{26} \mathrm{NO}_{5} \mathrm{~S}[\mathrm{M}+\mathrm{H}]^{+} 476.15$, found 476.20

\section{$\underline{\text { UNC7154 }}$}



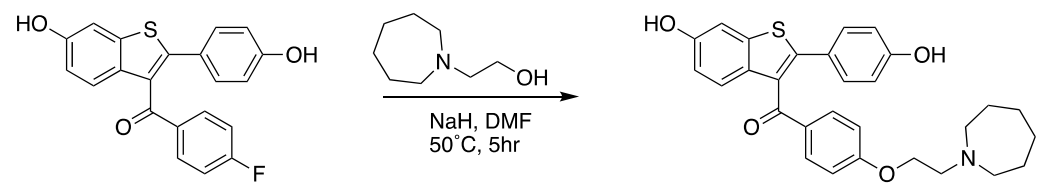

UNC7154

To a glass vial with septum was added 2-(azepan-1-yl)ethan-1-ol (18 mg, $5 \mathrm{Eq}, 0.12 \mathrm{mmol}$ ) and anhydrous DMF $(0.5 \mathrm{~mL})$. The vial was cooled in an ice-water bath and sodium hydride $(7.9 \mathrm{mg}$, $8 \mathrm{Eq}, 0.20 \mathrm{mmol}$ ) was added portionwise, then allowed to stir for 30 minutes while warming to room temperature. To the vial was then added (4-fluorophenyl)(6-hydroxy-2-(4hydroxyphenyl)benzo[b]thiophen-3-yl)methanone $(9.0 \mathrm{mg}, 1 \mathrm{Eq}, 25 \mu \mathrm{mol})$ (the reaction turns deep blood-red) and the reaction was heated to $50^{\circ} \mathrm{C}$ for 5 hours. The reaction was then cooled, quenched with water, acidified with TFA, and purified by reverse-phase chromatography $(10-100 \%$ methanol in water $+0.1 \%$ TFA). The collected fractions were concentrated and lyophilized to yield (4-(2-(azepan-1-yl)ethoxy)phenyl)(6-hydroxy-2-(4hydroxyphenyl)benzo[b]thiophen-3-yl)methanone 2,2,2-trifluoroacetate $(14.65 \mathrm{mg}, 99 \%)$ as a yellow solid.

${ }^{1} \mathrm{H}$ NMR $\left(400 \mathrm{MHz}\right.$, Methanol- $\left.d_{4}\right) \delta 7.73(\mathrm{~d}, J=8.9 \mathrm{~Hz}, 2 \mathrm{H}), 7.43(\mathrm{~d}, J=8.8 \mathrm{~Hz}, 1 \mathrm{H}), 7.26(\mathrm{~d}, J=$ $2.2 \mathrm{~Hz}, 1 \mathrm{H}), 7.17(\mathrm{~d}, J=8.6 \mathrm{~Hz}, 2 \mathrm{H}), 6.91(\mathrm{~d}, J=8.9 \mathrm{~Hz}, 2 \mathrm{H}), 6.87(\mathrm{dd}, J=8.8,2.3 \mathrm{~Hz}, 1 \mathrm{H})$, $6.60(\mathrm{~d}, J=8.6 \mathrm{~Hz}, 2 \mathrm{H}), 4.39-4.31(\mathrm{~m}, 2 \mathrm{H}), 3.62-3.56(\mathrm{~m}, 2 \mathrm{H}), 3.52$ (ddd, $J=13.8,7.7,2.3$ $\mathrm{Hz}, 2 \mathrm{H}), 3.30-3.22(\mathrm{~m}, 2 \mathrm{H}), 2.01-1.80(\mathrm{~m}, 4 \mathrm{H}), 1.79-1.65(\mathrm{~m}, 4 \mathrm{H})$.

LCMS (ESI, +ve mode) expected $m / z$ for $\mathrm{C}_{29} \mathrm{H}_{30} \mathrm{NO}_{4} \mathrm{~S}[\mathrm{M}+\mathrm{H}]^{+} 488.19$, found 488.20

\section{$\underline{\text { UNC7155 }}$}

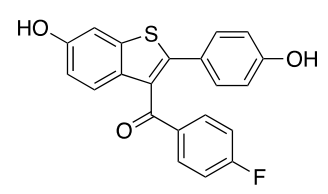

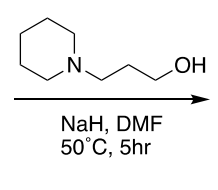

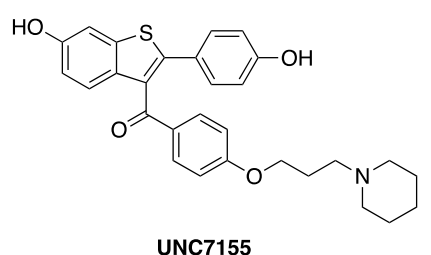

UNC7155

To a glass vial with septum was added 3-(piperidin-1-yl)propan-1-ol (18 mg, 5 Eq, $0.12 \mathrm{mmol}$ ) and anhydrous DMF $(0.5 \mathrm{~mL})$. The vial was cooled in an ice-water bath and sodium hydride (12 $\mathrm{mg}, 12 \mathrm{Eq}, 0.30 \mathrm{mmol}$ ) was added portionwise, then allowed to stir for 30 minutes while warming to room temperature. To the vial was then added (4-fluorophenyl)(6-hydroxy-2-(4hydroxyphenyl)benzo[b]thiophen-3-yl)methanone $(9.0 \mathrm{mg}, 1 \mathrm{Eq}, 25 \mu \mathrm{mol})$ (the reaction turns deep blood-red) and the reaction was heated to $50^{\circ} \mathrm{C}$ for 5 hours. The reaction was then cooled, quenched with water, acidified with TFA, and purified by reverse-phase chromatography $(10-100 \%$ methanol in water $+0.1 \%$ TFA). The collected fractions were concentrated and lyophilized to yield (6-hydroxy-2-(4-hydroxyphenyl)benzo[b]thiophen-3-yl)(4-(3-(piperidin-1yl)propoxy)phenyl)methanone 2,2,2-trifluoroacetate $(12.64 \mathrm{mg}, 85 \%)$ as a yellow solid. 
${ }^{1} \mathrm{H}$ NMR $\left(400 \mathrm{MHz}\right.$, Methanol- $\left.d_{4}\right) \delta 7.71(\mathrm{~d}, J=8.9 \mathrm{~Hz}, 2 \mathrm{H}), 7.41(\mathrm{~d}, J=8.8 \mathrm{~Hz}, 1 \mathrm{H}), 7.26(\mathrm{~d}, J=$ $2.3 \mathrm{~Hz}, 1 \mathrm{H}), 7.18(\mathrm{~d}, J=8.6 \mathrm{~Hz}, 2 \mathrm{H}), 6.89-6.80(\mathrm{~m}, 3 \mathrm{H}), 6.62(\mathrm{~d}, J=8.8 \mathrm{~Hz}, 2 \mathrm{H}), 4.09(\mathrm{t}, J=$ $5.7 \mathrm{~Hz}, 2 \mathrm{H}), 3.60-3.50(\mathrm{~m}, 2 \mathrm{H}), 3.28-3.19(\mathrm{~m}, 2 \mathrm{H}), 2.92(\mathrm{td}, J=12.6,3.0 \mathrm{~Hz}, 2 \mathrm{H}), 2.19(\mathrm{dq}, J$ $=11.4,5.7 \mathrm{~Hz}, 2 \mathrm{H}), 2.00-1.90(\mathrm{~m}, 2 \mathrm{H}), 1.88-1.66(\mathrm{~m}, 3 \mathrm{H}), 1.50(\mathrm{qt}, J=12.4,3.8 \mathrm{~Hz}, 1 \mathrm{H})$.

LCMS (ESI, +ve mode) expected $m / z$ for $\mathrm{C}_{29} \mathrm{H}_{29} \mathrm{NO}_{4} \mathrm{~S}[\mathrm{M}+\mathrm{H}]^{+} 488.19$, found 488.20

\section{$\underline{\text { UNC7156 }}$}
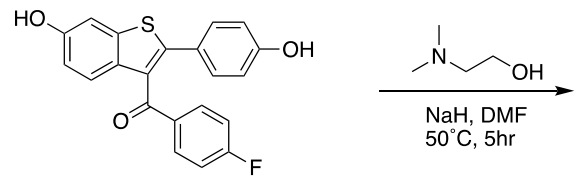

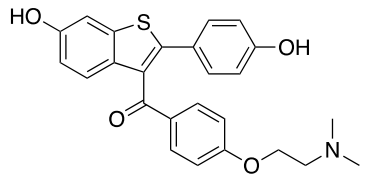

UNC7156

To a glass vial with septum was added 2-(dimethylamino)ethan-1-ol (11 mg, $5 \mathrm{Eq}, 0.12 \mathrm{mmol})$ and anhydrous DMF $(0.5 \mathrm{~mL})$. The vial was cooled in an ice-water bath and sodium hydride (12 $\mathrm{mg}, 12 \mathrm{Eq}, 0.30 \mathrm{mmol}$ ) was added portionwise, then allowed to stir for 30 minutes while warming to room temperature. To the vial was then added (4-fluorophenyl)(6-hydroxy-2-(4hydroxyphenyl)benzo[b]thiophen-3-yl)methanone $(9.0 \mathrm{mg}, 1 \mathrm{Eq}, 25 \mu \mathrm{mol})$ (the reaction turns deep blood-red) and the reaction was heated to $50^{\circ} \mathrm{C}$ for 5 hours. The reaction was then cooled, quenched with water, acidified with TFA, and purified by reverse-phase chromatography $(10-100 \%$ methanol in water $+0.1 \%$ TFA $)$. The collected fractions were concentrated and lyophilized to yield (4-(2-(dimethylamino)ethoxy)phenyl)(6-hydroxy-2-(4hydroxyphenyl)benzo[b]thiophen-3-yl)methanone 2,2,2-trifluoroacetate $(9.47 \mathrm{mg}, 70 \%)$ as a yellow solid.

${ }^{1} \mathrm{H}$ NMR $\left(400 \mathrm{MHz}\right.$, Methanol- $\left.d_{4}\right) \delta 7.74(\mathrm{~d}, J=8.9 \mathrm{~Hz}, 2 \mathrm{H}), 7.43(\mathrm{~d}, J=8.8 \mathrm{~Hz}, 1 \mathrm{H}), 7.26(\mathrm{~d}, J=$ $2.2 \mathrm{~Hz}, 1 \mathrm{H}), 7.17(\mathrm{~d}, J=8.7 \mathrm{~Hz}, 2 \mathrm{H}), 6.92(\mathrm{~d}, J=9.0 \mathrm{~Hz}, 2 \mathrm{H}), 6.87(\mathrm{dd}, J=8.8,2.3 \mathrm{~Hz}, 1 \mathrm{H})$, $6.61(\mathrm{~d}, J=8.6 \mathrm{~Hz}, 2 \mathrm{H}), 4.38-4.31(\mathrm{~m}, 2 \mathrm{H}), 3.60-3.52(\mathrm{~m}, 2 \mathrm{H}), 2.94(\mathrm{~s}, 6 \mathrm{H})$.

LCMS (ESI, +ve mode) expected $m / z$ for $\mathrm{C}_{25} \mathrm{H}_{24} \mathrm{NO}_{4} \mathrm{~S}[\mathrm{M}+\mathrm{H}]^{+} 434.14$, found 434.15

\section{$\underline{\text { UNC7157 }}$}
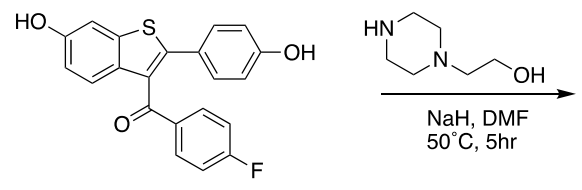

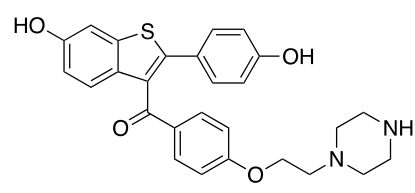

UNC7157

To a glass vial with septum was added 2-(piperazin-1-yl)ethan-1-ol (16 mg, $5 \mathrm{Eq}, 0.12 \mathrm{mmol})$ and anhydrous DMF $(0.5 \mathrm{~mL})$. The vial was cooled in an ice-water bath and sodium hydride (12 $\mathrm{mg}, 12 \mathrm{Eq}, 0.30 \mathrm{mmol}$ ) was added portionwise, then allowed to stir for 30 minutes while 
warming to room temperature. To the vial was then added (4-fluorophenyl)(6-hydroxy-2-(4hydroxyphenyl)benzo[b]thiophen-3-yl)methanone $(9.0 \mathrm{mg}, 1 \mathrm{Eq}, 25 \mu \mathrm{mol})$ (the reaction turns deep blood-red) and the reaction was heated to $50^{\circ} \mathrm{C}$ for 5 hours. The reaction was then cooled, quenched with water, acidified with TFA, and purified by reverse-phase chromatography $(10-100 \%$ methanol in water $+0.1 \%$ TFA $)$. The collected fractions were concentrated and lyophilized to yield (6-hydroxy-2-(4-hydroxyphenyl)benzo[b]thiophen-3-yl)(4-(2-(piperazin-1yl)ethoxy)phenyl)methanone 2,2,2-trifluoroacetate (12.04 mg, 83\%) as a yellow solid.

${ }^{1} \mathrm{H}$ NMR $\left(400 \mathrm{MHz}\right.$, Methanol- $\left.d_{4}\right) \delta 7.72(\mathrm{~d}, J=8.8 \mathrm{~Hz}, 2 \mathrm{H}), 7.41(\mathrm{~d}, J=8.8 \mathrm{~Hz}, 1 \mathrm{H}), 7.26(\mathrm{~d}, J=$ $2.2 \mathrm{~Hz}, 1 \mathrm{H}), 7.18(\mathrm{~d}, J=8.6 \mathrm{~Hz}, 2 \mathrm{H}), 6.91-6.83(\mathrm{~m}, 3 \mathrm{H}), 6.62(\mathrm{~d}, J=8.6 \mathrm{~Hz}, 2 \mathrm{H}), 4.32-4.24$ $(\mathrm{m}, 2 \mathrm{H}), 3.46-3.38(\mathrm{~m}, 4 \mathrm{H}), 3.30-3.23(\mathrm{~m}, 4 \mathrm{H})$. Note: $2 \mathrm{H}$ under residual methanol peak.

LCMS (ESI, +ve mode) expected $m / z$ for $\mathrm{C}_{27} \mathrm{H}_{27} \mathrm{~N}_{2} \mathrm{O}_{4} \mathrm{~S}[\mathrm{M}+\mathrm{H}]^{+} 475.17$, found 475.2 and 503.15 $[\mathrm{N}$-formyl $+\mathrm{H}]$ - very minor product based on NMR.

\section{UNC7158}
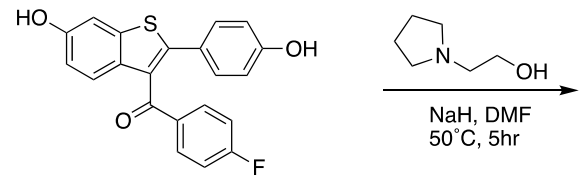

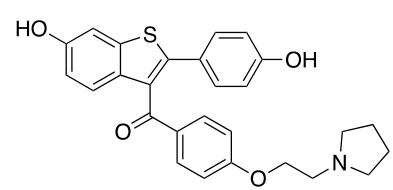

UNC7158

To a glass vial with septum was added 2-(pyrrolidin-1-yl)ethan-1-ol (14 mg, $5 \mathrm{Eq}, 0.12 \mathrm{mmol})$ and anhydrous DMF. The vial was cooled in an ice-water bath and sodium hydride $(12 \mathrm{mg}, 12$ $\mathrm{Eq}, 0.30 \mathrm{mmol}$ ) was added portionwise, then allowed to stir for 30 minutes while warming to room temperature. To the vial was then added (4-fluorophenyl)(6-hydroxy-2-(4hydroxyphenyl)benzo[b]thiophen-3-yl)methanone $(9 \mathrm{mg}, 1 \mathrm{Eq}, 25 \mu \mathrm{mol})$ (the reaction turns deep blood-red) and the reaction was heated to $50^{\circ} \mathrm{C}$ for 5 hours. The reaction was then cooled, quenched with water, acidified with TFA, and purified by reverse-phase chromatography $(10-100 \%$ methanol in water $+0.1 \%$ TFA $)$. The collected fractions were concentrated and lyophilized to yield (6-hydroxy-2-(4-hydroxyphenyl)benzo[b]thiophen-3-yl)(4-(2-(pyrrolidin-1yl)ethoxy)phenyl)methanone 2,2,2-trifluoroacetate $(7.02 \mathrm{mg}, 50 \%)$ as a yellow solid.

${ }^{1} \mathrm{H}$ NMR $\left(400 \mathrm{MHz}\right.$, Methanol- $\left.d_{4}\right) \delta 7.74(\mathrm{~d}, J=8.9 \mathrm{~Hz}, 2 \mathrm{H}), 7.44(\mathrm{~d}, J=8.8 \mathrm{~Hz}, 1 \mathrm{H}), 7.26(\mathrm{~d}, J=$ $2.2 \mathrm{~Hz}, 1 \mathrm{H}), 7.17(\mathrm{~d}, J=8.6 \mathrm{~Hz}, 2 \mathrm{H}), 6.92(\mathrm{~d}, J=8.9 \mathrm{~Hz}, 2 \mathrm{H}), 6.87(\mathrm{dd}, J=8.8,2.3 \mathrm{~Hz}, 1 \mathrm{H})$, $6.61(\mathrm{~d}, J=8.6 \mathrm{~Hz}, 2 \mathrm{H}), 4.37-4.28(\mathrm{~m}, 2 \mathrm{H}), 3.68(\mathrm{~s}, 2 \mathrm{H}), 3.65-3.58(\mathrm{~m}, 2 \mathrm{H}), 3.23-3.10(\mathrm{~m}$, $2 \mathrm{H}), 2.23-1.94(\mathrm{~m}, 4 \mathrm{H})$.

LCMS (ESI, +ve mode) expected $m / z$ for $\mathrm{C}_{27} \mathrm{H}_{26} \mathrm{NO}_{4} \mathrm{~S}[\mathrm{M}+\mathrm{H}]^{+} 460.16$, found 460.15

\section{$\underline{\text { UNC7159 }}$}



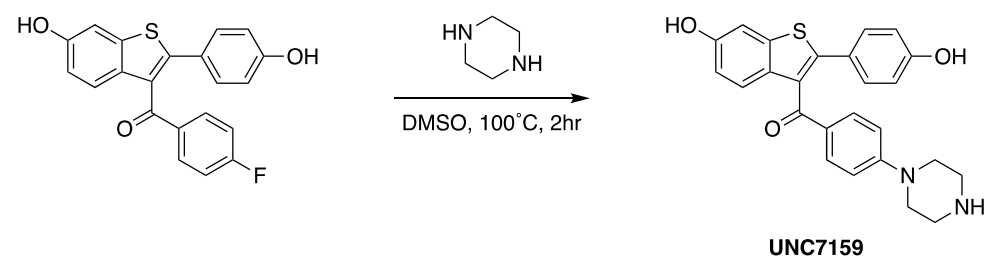

To a 2-dram glass vial was added (4-fluorophenyl)(6-hydroxy-2-(4-

hydroxyphenyl)benzo[b]thiophen-3-yl)methanone ( $8.0 \mathrm{mg}, 1 \mathrm{Eq}, 22 \mu \mathrm{mol})$, piperazine (32 mg, $17 \mathrm{Eq}, 0.37 \mathrm{mmol})$, and DMSO $(0.25 \mathrm{~mL})$. The vial was capped and heated to $120^{\circ} \mathrm{C}$ for a 4 hour period. LCMS analysis of an aliquot indicated reaction completion. The reaction mixture was diluted with $0.8 \mathrm{~mL}$ of water and purified by reverse-phase chromatography $(10-100 \%$ methanol in water $+0.1 \%$ TFA), concentrated, and lyophilized to yield (6-hydroxy-2-(4hydroxyphenyl)benzo[b]thiophen-3-yl)(4-(piperazin-1-yl)phenyl)methanone 2,2,2-trifluoroacetate $(8.78 \mathrm{mg}, 73 \%)$ as a yellow solid.

${ }^{1} \mathrm{H}$ NMR $\left(400 \mathrm{MHz}\right.$, Methanol- $\left.d_{4}\right) \delta 7.66(\mathrm{~d}, J=9.0 \mathrm{~Hz}, 2 \mathrm{H}), 7.35(\mathrm{~d}, J=8.8 \mathrm{~Hz}, 1 \mathrm{H}), 7.24(\mathrm{~d}, J=$ $2.2 \mathrm{~Hz}, 1 \mathrm{H}), 7.18(\mathrm{~d}, J=8.6 \mathrm{~Hz}, 2 \mathrm{H}), 6.86(\mathrm{~d}, J=9.1 \mathrm{~Hz}, 2 \mathrm{H}), 6.83(\mathrm{dd}, J=8.8,2.3 \mathrm{~Hz}, 1 \mathrm{H})$, $6.61(\mathrm{~d}, J=8.6 \mathrm{~Hz}, 2 \mathrm{H}), 3.56-3.51(\mathrm{~m}, 4 \mathrm{H}), 3.29-3.25(\mathrm{~m}, 4 \mathrm{H})$.

LCMS (ESI, +ve mode) expected $m / z$ for $\mathrm{C}_{25} \mathrm{H}_{23} \mathrm{~N}_{2} \mathrm{O}_{3} \mathrm{~S}[\mathrm{M}+\mathrm{H}]^{+} 431.14$, found 431.15

HRMS (ESI, +ve mode) expected $m / z$ for $\mathrm{C}_{25} \mathrm{H}_{23} \mathrm{~N}_{2} \mathrm{O}_{3} \mathrm{~S}[\mathrm{M}+\mathrm{H}]^{+} 431.14239$, found 431.14176

\section{UNC7265}

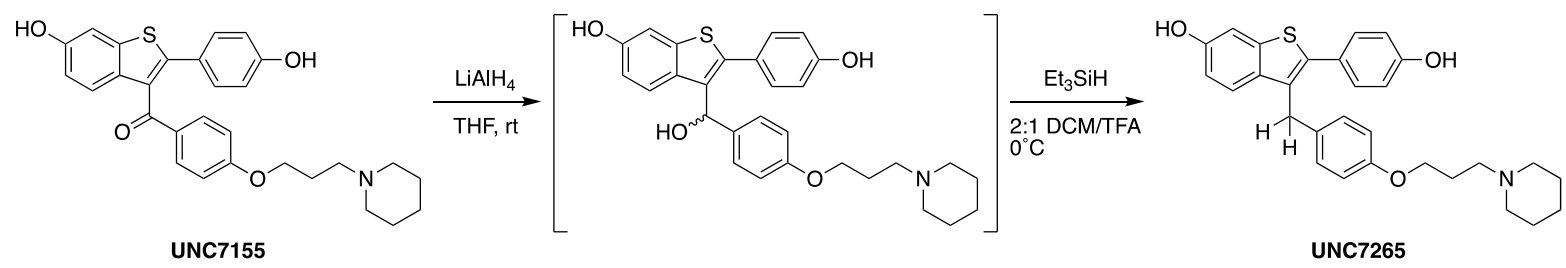

To a vial containing (6-hydroxy-2-(4-hydroxyphenyl)benzo[b]thiophen-3-yl)(4-(3-(piperidin-1yl)propoxy)phenyl)methanone 2,2,2-trifluoroacetate $(6.0 \mathrm{mg}, 1 \mathrm{Eq}, 10 \mu \mathrm{mol})$ was added THF (1 $\mathrm{mL}$ ) and cooled in an ice-water bath. $\mathrm{LiAlH}_{4}(4.5 \mathrm{mg}, 12 \mathrm{Eq}, 0.12 \mathrm{mmol})$ was added cautiously and the reaction was allowed to come to room temperature with stirring. When LCMS of a quenched aliquot indicated complete conversion, the reaction was quenched with $1 \mathrm{~mL}$ saturated sodium bicarbonate followed by $4 \mathrm{~mL}$ of $0.5 \mathrm{M}$ Rochelle salt, diluted with ethyl acetate, and allowed to stir until 2 phases formed. The organic layer was separated, and the aqueous layer extracted twice more with ethyl acetate. The combined organic layers were washed once more with Rochelle salt, once with water, once with brine, then dried by passage through a phase separator and concentrated to a yellow residue that was used without further purification or characterization. 
To the vial containing the reduction product was added DCM $(0.5 \mathrm{~mL})$ and triethylsilane $(1.5 \mathrm{mg}$, $2.1 \mu \mathrm{L}, 1.3 \mathrm{Eq}, 13 \mu \mathrm{mol})$ and cooled in an ice-water bath under nitrogen atmosphere. To the stirring solution was added TFA $(0.25 \mathrm{~mL})$ dropwise - formation of the benzylic cation was characterized by a blue color, which rapidly disappeared upon silane reduction. Upon reaction completion as indicated by LCMS, the solvents were removed in vacuo and the residue purified by reverse-phase chromatography (10-100\% methanol in water $+0.1 \%$ TFA), concentrated, and lyophilized to yield 2-(4-hydroxyphenyl)-3-(4-(3-(piperidin-1-yl)propoxy)benzyl)benzo[b]thiophen6 -ol 2,2,2-trifluoroacetate (4.22 $\mathrm{mg}, 72 \%$ over two steps) as a white solid.

${ }^{1} \mathrm{H}$ NMR $\left(400 \mathrm{MHz}\right.$, Methanol- $\left.d_{4}\right) \delta 7.29-7.24(\mathrm{~m}, 3 \mathrm{H}), 7.16(\mathrm{~d}, J=2.3 \mathrm{~Hz}, 1 \mathrm{H}), 7.02(\mathrm{~d}, J=8.6$ $\mathrm{Hz}, 2 \mathrm{H}), 6.80(\mathrm{~d}, J=6.2 \mathrm{~Hz}, 2 \mathrm{H}), 6.78(\mathrm{~d}, J=6.2 \mathrm{~Hz}, 2 \mathrm{H}), 6.74(\mathrm{dd}, J=8.7,2.3 \mathrm{~Hz}, 1 \mathrm{H}), 4.10$ $(\mathrm{s}, 2 \mathrm{H}), 4.03(\mathrm{t}, J=5.7 \mathrm{~Hz}, 2 \mathrm{H}), 3.96(\mathrm{~s}, 1 \mathrm{H}$, presumably $\mathrm{OH}), 3.60-3.50(\mathrm{~m}, 2 \mathrm{H}), 3.27-3.21$ (m, 2H), $2.92(\mathrm{td}, J=12.5,3.0 \mathrm{~Hz}, 2 \mathrm{H}), 2.16(\mathrm{dq}, J=11.3,5.6 \mathrm{~Hz}, 2 \mathrm{H}), 1.99-1.89(\mathrm{~m}, 2 \mathrm{H})$, $1.88-1.64(\mathrm{~m}, 3 \mathrm{H}), 1.50$ (qt, $J=12.4,3.7 \mathrm{~Hz}, 1 \mathrm{H}$ ).

LCMS (ESI, +ve mode) expected $\mathrm{m} / z$ for $\mathrm{C}_{29} \mathrm{H}_{32} \mathrm{NO}_{3} \mathrm{~S}[\mathrm{M}+\mathrm{H}]^{+} 474.21$, found 474.20

\section{UNC7267}

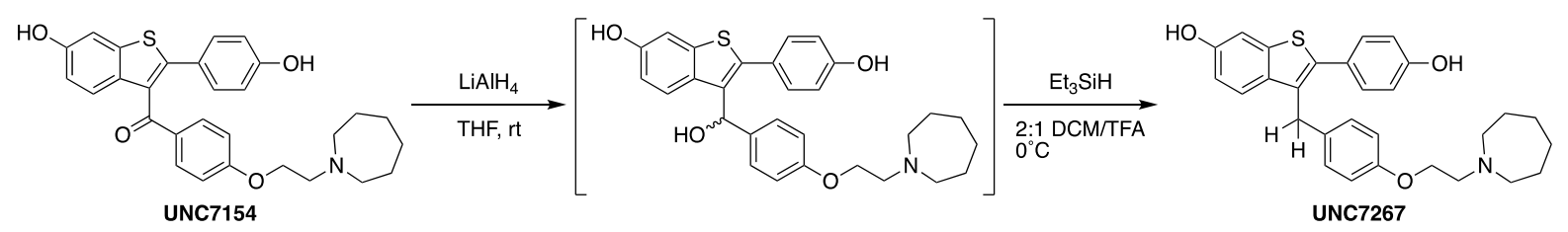

To a vial containing (4-(2-(azepan-1-yl)ethoxy)phenyl)(6-hydroxy-2-(4hydroxyphenyl)benzo[b]thiophen-3-yl)methanone 2,2,2-trifluoroacetate $(7.0 \mathrm{mg}, 1 \mathrm{Eq}, 12 \mu \mathrm{mol})$ was added THF (1 mL) and cooled in an ice-water bath. $\mathrm{LiAlH}_{4}(4.4 \mathrm{mg}, 10 \mathrm{Eq}, 0.12 \mathrm{mmol})$ was added cautiously and the reaction was allowed to come to room temperature with stirring. When LCMS of a quenched aliquot indicated complete conversion, the reaction was quenched with 1 $\mathrm{mL}$ saturated sodium bicarbonate followed by $4 \mathrm{~mL}$ of $0.5 \mathrm{M}$ Rochelle salt, diluted with ethyl acetate, and allowed to stir until 2 phases formed. The organic layer was separated, and the aqueous layer extracted twice more with ethyl acetate. The combined organic layers were washed once more with Rochelle salt, once with water, once with brine, then dried by passage through a phase separator and concentrated to a yellow residue that was used without further purification or characterization.

To the vial containing the reduction product was added DCM $(0.5 \mathrm{~mL})$ and triethylsilane $(1.8 \mathrm{mg}$, $2.4 \mu \mathrm{L}, 1.3 \mathrm{Eq}, 15 \mu \mathrm{mol})$ and cooled in an ice-water bath under nitrogen atmosphere. To the stirring solution was added TFA $(250 \mu \mathrm{L})$ dropwise - formation of the benzylic cation was characterized by a blue color, which rapidly disappeared upon silane reduction. Upon reaction completion as indicated by LCMS, the solvents were removed in vacuo and the residue purified by reverse-phase chromatography (10-100\% methanol in water $+0.1 \%$ TFA), concentrated, and 
lyophilized to yield 3-(4-(2-(azepan-1-yl)ethoxy)benzyl)-2-(4-hydroxyphenyl)benzo[b]thiophen-6ol 2,2,2-trifluoroacetate ( $4.12 \mathrm{mg}, 60 \%$ over two steps) as a white solid.

${ }^{1} \mathrm{H}$ NMR $\left(400 \mathrm{MHz}\right.$, Methanol- $\left.d_{4}\right) \delta 7.29-7.24(\mathrm{~m}, 3 \mathrm{H}), 7.17$ (dd, $\left.J=2.3,0.5 \mathrm{~Hz}, 1 \mathrm{H}\right), 7.05(\mathrm{~d}, J$ $=8.7 \mathrm{~Hz}, 2 \mathrm{H}), 6.87(\mathrm{~d}, J=8.7 \mathrm{~Hz}, 2 \mathrm{H}), 6.78(\mathrm{~d}, J=8.6 \mathrm{~Hz}, 2 \mathrm{H}), 6.73(\mathrm{dd}, J=8.7,2.3 \mathrm{~Hz}, 1 \mathrm{H})$, $4.31-4.24(\mathrm{~m}, 2 \mathrm{H}), 4.12(\mathrm{~s}, 2 \mathrm{H}), 3.61-3.46(\mathrm{~m}, 4 \mathrm{H}), 3.33-3.29(\mathrm{~m}, 2 \mathrm{H}), 2.01-1.80(\mathrm{~m}, 4 \mathrm{H})$, $1.79-1.65(\mathrm{~m}, 4 \mathrm{H})$.

LCMS (ESI, +ve mode) expected $m / z$ for $\mathrm{C}_{29} \mathrm{H}_{32} \mathrm{NO}_{3} \mathrm{~S}[\mathrm{M}+\mathrm{H}]^{+} 474.21$, found 474.20

\section{$\underline{\text { UNC7268 }}$}

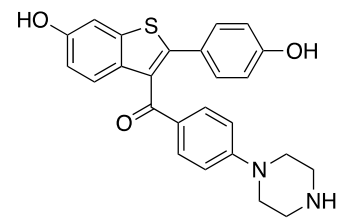

UNC7159

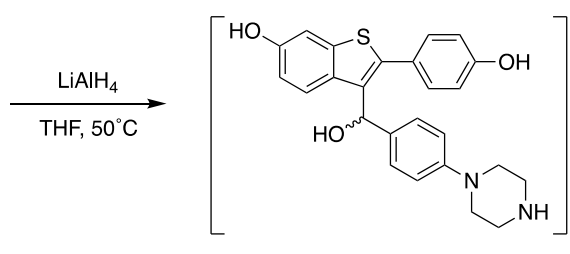

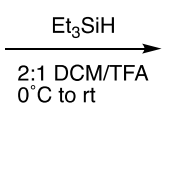

To a dry flask was added 6-hydroxy-2-(4-hydroxyphenyl)benzo[b]thiophen-3-yl)(4-(piperazin-1yl)phenyl)methanone 2,2,2-trifluoroacetate $(6.0 \mathrm{mg}, 1 \mathrm{Eq}, 11 \mu \mathrm{mol})$ and anhydrous THF (1 mL). The flask was cooled in an ice-water bath, and $\mathrm{LiAlH}_{4}(17 \mathrm{mg}, 40 \mathrm{Eq}, 0.44 \mathrm{mmol})$ was added cautiously. The flask was then brought to room temperature, a water-cooled condenser attached, and the reaction was heated at reflux under nitrogen atmosphere for 8 hours. LC-MS analysis of a quenched aliquot indicated complete conversion to the alcohol. The reaction was cooled and quenched with $1 \mathrm{~mL}$ of saturated sodium bicarbonate followed by $4 \mathrm{~mL}$ of $0.5 \mathrm{M}$ Rochelle salt and $5 \mathrm{~mL}$ of ethyl acetate and allowed to stir for 1 hour to achieve layer separation. The layers were separated, and the aqueous layer extracted a further 4 times with ethyl acetate. The combined organic layers were washed once more with Rochelle salt, once with water, and once with brine, then dried by filtration through a phase separator and concentrated to a yellowish residue that was used without further purification or characterization.

To a pear-shaped flask was added (6-hydroxy-2-(4-hydroxyphenyl)benzo[b]thiophen-3-yl)(4(piperazin-1-yl)phenyl)methanone 2,2,2-trifluoroacetate $(6.0 \mathrm{mg}, 1 \mathrm{Eq}, 11 \mu \mathrm{mol})$ in ethyl acetate, which was removed in vacuo to concentrate the starting material at the bottom of the flask (the starting alcohol does not dissolve in DCM). To the flask was added DCM (1 mL) and triethylsilane (32 mg, $44 \mu \mathrm{L}, 25 \mathrm{Eq}, 0.28 \mathrm{mmol}$ ), and the flask was cooled in an ice-water bath under nitrogen. To the stirring suspension was added TFA (500 $\mu \mathrm{L})$ dropwise, taking care to wash down all sides of the flask, and upon complete addition the flask was swirled to solubilize any leftover starting material. The cationic intermediate produced on TFA exposure is a deep, vivid blue, and silane reduction results in a pale peach color. The flask was left to stir for 4 hours with monitoring by LCMS. Upon reaction completion, the reaction was diluted with DCM, then 
concentrated on the rotary evaporator to a yellow-grey residue. Purification by reverse-phase chromatography (10-100\% methanol in water $+0.1 \%$ TFA), concentration, and lyophilization yielded 2-(4-hydroxyphenyl)-3-(4-(piperazin-1-yl)benzyl)benzo[b]thiophen-6-ol 2,2,2trifluoroacetate $(2.09 \mathrm{mg}, 36 \%$ over two steps) as an off-white solid.

${ }^{1} \mathrm{H}$ NMR (400 MHz, Methanol- $\left.d_{4}\right) \delta 7.29-7.24(\mathrm{~m}, 3 \mathrm{H}), 7.17(\mathrm{~d}, J=2.2 \mathrm{~Hz}, 1 \mathrm{H}), 7.03(\mathrm{~d}, J=8.5$ $\mathrm{Hz}, 2 \mathrm{H}), 6.89$ (d, J=8.7 Hz, 2H), 6.78 (d, $J=8.7 \mathrm{~Hz}, 2 \mathrm{H}), 6.74$ (dd, $J=8.7,2.3 \mathrm{~Hz}, 1 \mathrm{H}), 4.10$ (s, $2 \mathrm{H})$. Note: piperazine protons do not appear.

LCMS (ESI, +ve mode) expected $m / z$ for $\mathrm{C}_{25} \mathrm{H}_{25} \mathrm{~N}_{2} \mathrm{O}_{2} \mathrm{~S}[\mathrm{M}+\mathrm{H}]^{+} 417.16$, found 417.20 


\section{Supporting Tables}

Table S1. GUS activity of 31 GUS enzymes examined with 4-MUG

\begin{tabular}{|c|c|c|c|}
\hline GUS & PDB Accession ID ${ }^{a}$ & GenBank Accession ID & RFU \\
\hline$(-)$ GUS & & & $102 \pm 5$ \\
\hline A. muciniphila & & WP_102732122.1 & $7685 \pm 43$ \\
\hline A. species CAG: 344 & & WP_102727023.1 & $7699 \pm 42$ \\
\hline B. coprocola & & CDA71244.1 & $5460 \pm 24$ \\
\hline B. dorei & $6 \mathrm{ED} 1^{27}$ & WP_130053801.1 & $5678 \pm 30$ \\
\hline B. fragilis & $3 \mathrm{CMG}$ & WP_005822521.1 & $5468 \pm 67$ \\
\hline B. fragilis2 & & WP_005822521.1 & $3880 \pm 27$ \\
\hline B. multispecies & $6 \mathrm{D} 8 \mathrm{~K}^{29}$ & WP_0551677111.1 & $3245 \pm 45$ \\
\hline B. nordii & & WP_025866948.1 & $2343 \pm 25$ \\
\hline B. ovatus & & EDO11197.1 & $10003 \pm 70$ \\
\hline B. ovatus $(m L 1,2)$ & & WP_004298526.1 & $8965 \pm 25$ \\
\hline BuGUS1 & $6 \mathrm{D} \mathrm{W}^{29}$ & WP_117588613.1 & $5678 \pm 54$ \\
\hline BuGUS2 & $5 \cup J 6^{25}$ & WP_122375735.1 & $12343 \pm 43$ \\
\hline BuGUS3 & $6 \mathrm{D} 1 \mathrm{P}^{29}$ & WP_016272112.1 & $4323 \pm 32$ \\
\hline C. perfringens & $4 \mathrm{JKM}^{16}$ & WP_022502167.1 & $15673 \pm 57$ \\
\hline E. coli & $3 \mathrm{LPF}^{15}$ & WP_001551153.1 & $18456 \pm 43$ \\
\hline E. eligens & $6 B J W^{26}$ & CDA40053.1 & $17654 \pm 69$ \\
\hline F. bacterium CAG: 95 & & HCG85850.1 & $4353 \pm 23$ \\
\hline F. prausnitzii & $6 \mathrm{ED} 2^{27}$ & SCH31850.1 & $10453 \pm 46$ \\
\hline F. saccharivorans & $6 \mathrm{NCY}^{4^{*}}$ & WP_069152983.1 & $4554 \pm 54$ \\
\hline$F p L 2-6$ & $6 \mathrm{MVF}^{32}$ & CBK98066.1 & $7890 \pm 25$ \\
\hline H11G11 & & CBJ55484.1 & $8000 \pm 50$ \\
\hline L. rhamnosus & $6 \mathrm{ECA}^{27}$ & HBH98519.1 & $8764 \pm 57$ \\
\hline P. merdae & $6 \mathrm{D} 7 \mathrm{~J}^{3^{*}}$ & WP_122205889.1 & $6745 \pm 32$ \\
\hline P. multispecies & & WP_010800018.1 & $8790 \pm 67$ \\
\hline$R$. gnavus & $6 \mathrm{EC} 6^{27}$ & WP_118445354.1 & $7865 \pm 35$ \\
\hline$R$. gnavus2 & & WP_118587093 & $5434 \pm 52$ \\
\hline R. gnavus3 & $6 \mathrm{MVG}^{32}$ & WP_118581144.1 & $12595 \pm 25$ \\
\hline R. hominis & & CU031707.1 & $10234 \pm 76$ \\
\hline R. hominis2 & $6 \mathrm{MVH}^{32}$ & WP_118096903.1 & $11500 \pm 40$ \\
\hline R. inulinvorans & & WP_055167711.1 & $7891 \pm 58$ \\
\hline S. agalactiae & $4 \mathrm{JKK}^{16}$ & CDE36900.1 & $13495 \pm 86$ \\
\hline
\end{tabular}

aSuperscripted numbers refer to literature citations in our listed references. ${ }^{b} \mathrm{Accession}$ ${ }^{*}$ References can be found in Supporting Information. IDs are from NCBI. Data are presented in $\mu \mathrm{M}$ as the average of 3 biological replicates \pm SEM. RFU, relative fluorescence units for 15 minute incubation with the fluorescent GUS reporter substrate 4-MUG.

Table S2. Catalytic efficiency of 4-MUG by FpL2-6, H11G11, Rg3 and Rh2 GUS enzymes 


\begin{tabular}{c|c} 
GUS & $\mathbf{k}_{\mathrm{cat}} / \mathbf{K}_{\mathrm{m}}\left(\mathbf{s}^{-1} \mathbf{M}^{-1}\right.$ \\
\hline R. gnavus3 & $5.4 \times 10^{5 *}$ \\
R. hominis2 & $2.21 \times 10^{5 *}$ \\
H11G11 & $8.92 \times 10^{4}$ \\
FpL2-6 & $4.57 \times 10^{5 *}$
\end{tabular}

Data are presented as the average of 3 biological replicates and $\mathrm{k}_{\mathrm{cat}} / K_{\mathrm{m}}$ is catalytic efficiency. ${ }^{*}$ Data were previously reported in Pellock et al ${ }^{28}$.

Table S3. Analog by catalog: IC $\mathrm{C}_{50}(\mu \mathrm{M})$ for the 4 GUS enzymes involved in regorafenibglucuronide processing

\begin{tabular}{|cc|c|c|c|} 
& FpL2-6 & H11G11 & Rg3GUS & Rh2GUS \\
\hline \hline Acolbifene & $100 \pm 6$ & $>100$ & $28 \pm 4$ & $45 \pm 5$ \\
Bazedoxifene & $50 \pm 7$ & $>100$ & $3 \pm 1$ & $4 \pm 1$ \\
Lasofoxifene & $>100$ & $>100$ & $26 \pm 2$ & $3 \pm 1$ \\
Raloxifene & $78 \pm 9$ & $100 \pm 5$ & $13 \pm 2$ & $13 \pm 3$ \\
\hline Propylpyrazole Triol & $>100$ & $52 \pm 2$ & $42 \pm 6$ & $12 \pm 1$ \\
Tamoxifen & $\mathrm{NI}$ & $\mathrm{NI}$ & $\mathrm{NI}$ & $\mathrm{NI}$ \\
\hline (R)-Equol & $\mathrm{NI}$ & $\mathrm{NI}$ & $\mathrm{NI}$ & $\mathrm{NI}$ \\
(S)-Equol & $\mathrm{NI}$ & $\mathrm{NI}$ & $\mathrm{NI}$ & $\mathrm{NI}$ \\
Abemiciclib & $\mathrm{NI}$ & $\mathrm{NI}$ & $29 \pm 3$ & $33 \pm 5$ \\
Fulvestrant & $\mathrm{NI}$ & $\mathrm{NI}$ & $\mathrm{NI}$ & $\mathrm{NI}$ \\
Palbiciclib & $>100$ & $98 \pm 3$ & $36 \pm 4$ & $26 \pm 3$ \\
Premarin & $\mathrm{NI}$ & $\mathrm{NI}$ & $\mathrm{NI}$ & $\mathrm{NI}$ \\
\hline
\end{tabular}

Raloxifene-like SERM Tamoxifen-like SERM Non-SERM

${ }^{*} \mathrm{NI}=$ No inhibition

Data are presented in $\mu \mathrm{M}$ as the average of 3 biological replicates \pm SEM

Table S4. SAR: IC ${ }_{50}(\mu \mathrm{M})$ of the 4 GUS enzymes involved in regorafenib-glucuronide processing 
Data are presented in $\mu \mathrm{M}$ as the average of 3 biological replicates \pm SEM

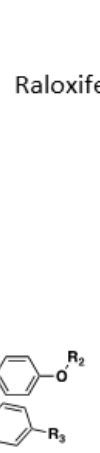
R1

\begin{tabular}{|c|c|c|c|c|c|c|c|}
\hline R1 & R2 & $Y$ & R3 & FpL2-6 & H11G11 & Rg3GUS & Rh2GUS \\
\hline $\mathrm{H}$ & $\mathrm{H}$ & $\mathrm{C}=\mathrm{O}$ & 10.0 & $78 \pm 9$ & $100 \pm 5$ & $13 \pm 2$ & $13 \pm 3$ \\
\hline $\mathrm{H}$ & $\mathrm{CH}_{3}$ & $\mathrm{C}=\mathrm{O}$ & $x_{0} \sim 0$ & $84 \pm 6$ & $50 \pm 7$ & $13 \pm 2$ & $13 \pm 4$ \\
\hline $\mathrm{CH}_{3}$ & $\mathrm{H}$ & $\mathrm{C}=\mathrm{O}$ & roo D & $81 \pm 6$ & $44 \pm 5$ & $51 \pm 5$ & $25 \pm 3$ \\
\hline $\mathrm{CH}_{3}$ & $\mathrm{CH}_{3}$ & $\mathrm{C}=\mathrm{O}$ & $\lambda_{0} \sim 0$ & $>100$ & $>100$ & $50 \pm 5$ & $33 \pm 5$ \\
\hline $\mathrm{H}$ & $\mathrm{H}$ & $\mathrm{CH}_{2}$ & $x_{0} \sim D$ & $18 \pm 3$ & $16 \pm 3$ & $5 \pm 1$ & $7 \pm 3$ \\
\hline $\mathrm{CH}_{3}$ & $\mathrm{CH}_{3}$ & $\mathrm{C}=\mathrm{O}$ & 10,00 & $47 \pm 9$ & $55 \pm 2$ & $4 \pm 1$ & $16 \pm 3$ \\
\hline $\mathrm{CH}_{3}$ & $\mathrm{CH}_{3}$ & $\mathrm{C}=\mathrm{O}$ & $1 \mathrm{Or}_{\mathrm{sen}}$ & $75 \pm 6$ & $49 \pm 7$ & $6 \pm 1$ & $4 \pm 1$ \\
\hline $\mathrm{CH}_{3}$ & $\mathrm{CH}_{3}$ & $\mathrm{C}=\mathrm{O}$ & rom & $15 \pm 1$ & $16 \pm 1$ & $4 \pm 1$ & $2 \pm 1$ \\
\hline $\mathrm{H}$ & H & None & None & $>100$ & $>100$ & $>100$ & $>100$ \\
\hline $\mathrm{H}$ & $\mathrm{H}$ & $\mathrm{C}=\mathrm{O}$ & $1 \mathrm{O}_{\mathrm{atan}}$ & $17 \pm 3$ & $63 \pm 6$ & $4 \pm 1$ & $7 \pm 1$ \\
\hline $\mathrm{H}$ & $\mathrm{H}$ & $\mathrm{C}=\mathrm{O}$ & row & $>100$ & $>100$ & $>100$ & $>100$ \\
\hline $\mathrm{H}$ & $\mathrm{H}$ & $\mathrm{C}=\mathrm{O}$ & $x_{0} \sim D$ & $29 \pm 4$ & $43 \pm 10$ & $5 \pm 1$ & $23 \pm 6$ \\
\hline $\mathrm{H}$ & $\mathrm{H}$ & $\mathrm{C}=\mathrm{O}$ & $10 \sim 0$ & $14 \pm 2$ & $48 \pm 6$ & $12 \pm 1$ & $33 \pm 5$ \\
\hline $\mathrm{H}$ & $\mathrm{H}$ & $\mathrm{C}=\mathrm{O}$ & $\alpha_{0} \sim a^{2}$ & $>100$ & $83 \pm 8$ & $75 \pm 11$ & $57 \pm 9$ \\
\hline $\mathrm{H}$ & $\mathrm{H}$ & $\mathrm{C}=\mathrm{O}$ & 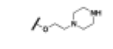 & $60 \pm 9$ & $53 \pm 4$ & $9 \pm 1$ & $7 \pm 1$ \\
\hline $\mathrm{H}$ & $\mathrm{H}$ & $\mathrm{C}=\mathrm{O}$ & $\left.r_{0} \sim D_{0}\right)$ & $>100$ & $52 \pm 8$ & $55 \pm 6$ & $25 \pm 4$ \\
\hline $\mathrm{H}$ & $\mathrm{H}$ & $\mathrm{C}=\mathrm{O}$ & 10 & $13 \pm 1$ & $14 \pm 1$ & $7 \pm 2$ & $3 \pm 1$ \\
\hline $\mathrm{H}$ & $\mathrm{H}$ & $\mathrm{CH}_{2}$ & rono & $13 \pm 2$ & $40 \pm 8$ & $24 \pm 2$ & $12 \pm 1$ \\
\hline $\mathrm{H}$ & $\mathrm{H}$ & $\mathrm{CH}_{2}$ & $t_{0} \sim 0$ & $35 \pm 5$ & $45 \pm 5$ & $25 \pm 3$ & $27 \pm 3$ \\
\hline $\mathrm{H}$ & $\mathrm{H}$ & $\mathrm{CH}_{2}$ & ro. O & $11 \pm 2$ & $32 \pm 5$ & $7 \pm 1$ & $6 \pm 1$ \\
\hline H & H & $\mathrm{CH}_{2}$ & $\mathrm{Ar}_{\mathrm{n}}$ & $12 \pm 2$ & $25 \pm 2$ & $9 \pm 1$ & $5 \pm 1$ \\
\hline
\end{tabular}




\section{Supporting Figures}

Figure S1. Terminal and Central Glucuronides.
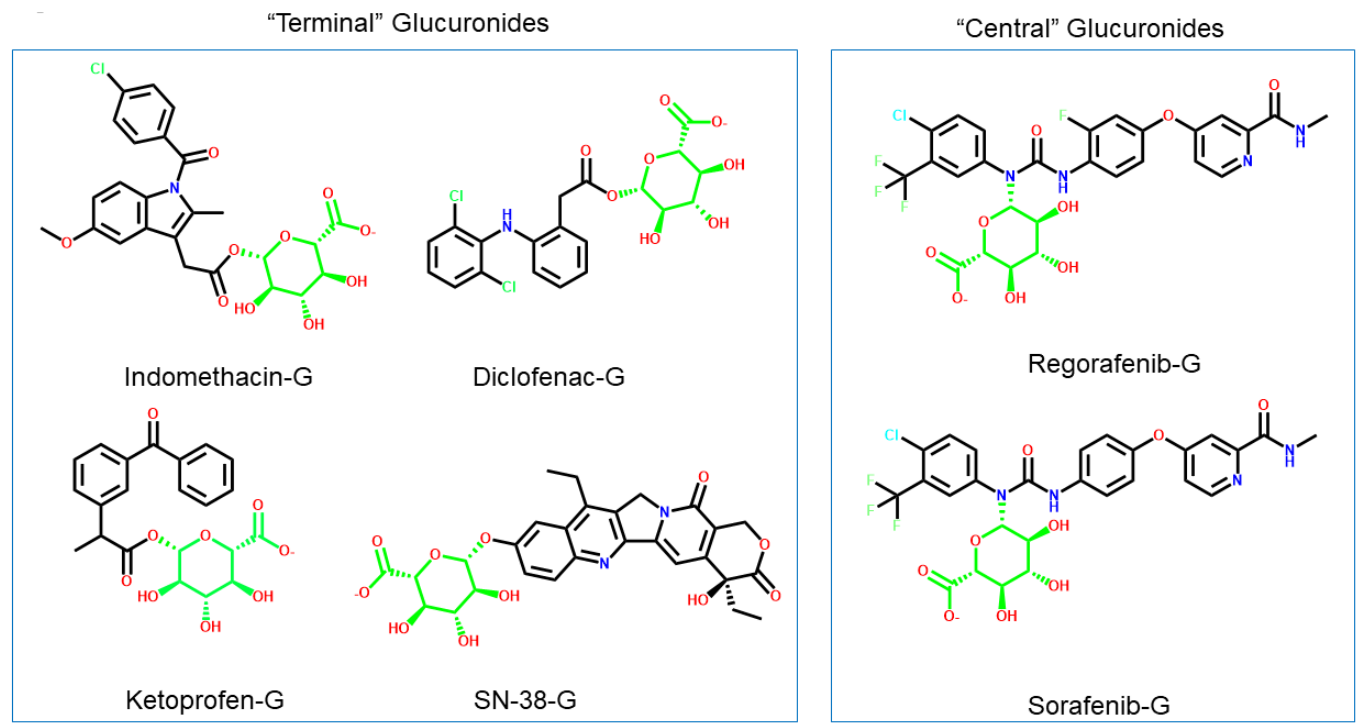

Figure S2. Structural Basis for Regorafenib-Glucuronide Processing. A. Rates of Rg3GUS mutants incubated with 4-MUG, created to probe activity with regorafenib-glucuronide. B. 4MUG modeled in GUS active site, highlighting point mutants. Catalytic glutamates are highlighted in magenta.

A

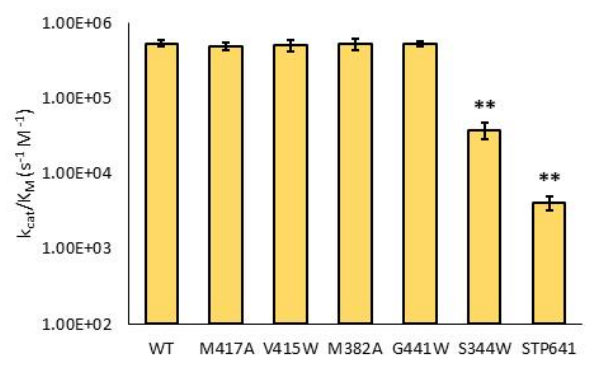

B

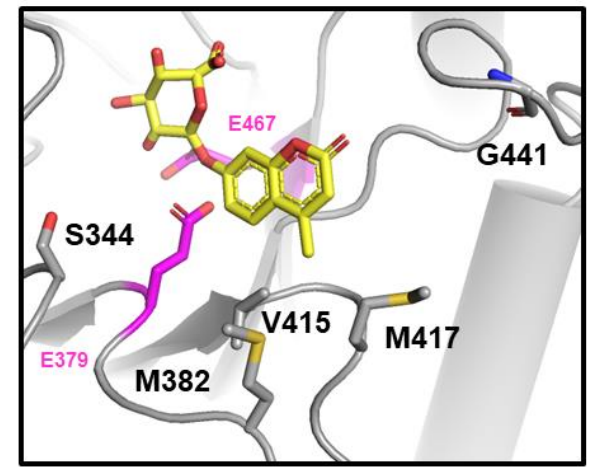

Figure S3. Circular dichroism wavelength scan and melting temperature 

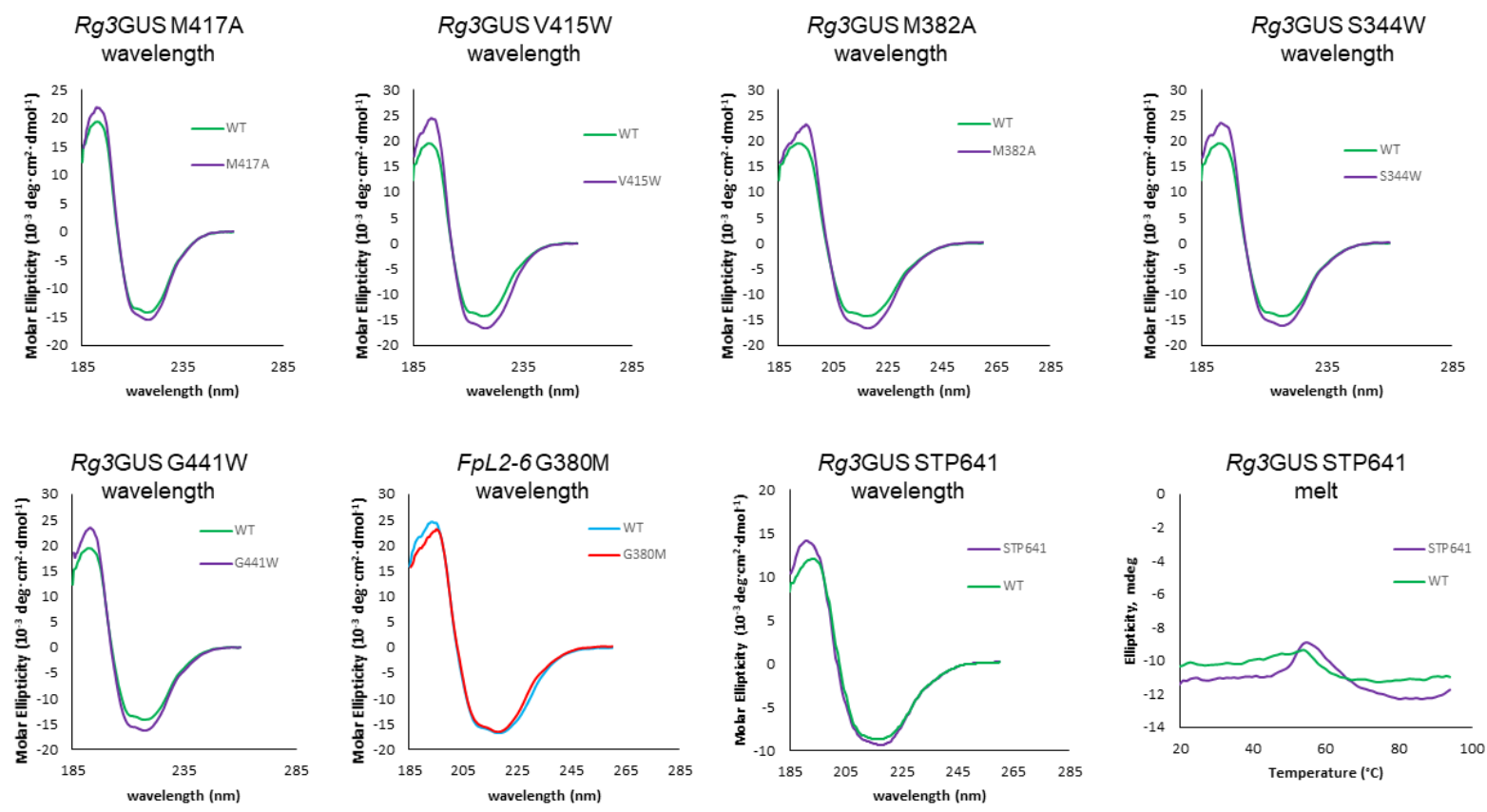

Figure S4. Steric Occlusion by GUS Orthologs. Regorafenib-glucuronide is modeled in each of the active site architectures (L1, L2, NL, mL1, $\mathrm{mL2}, \mathrm{mL} 1,2)$ overlaid with Rg3GUS (grey). Each ortholog contains active site features preventing regorafenib-glucuronide binding (shown in black box).
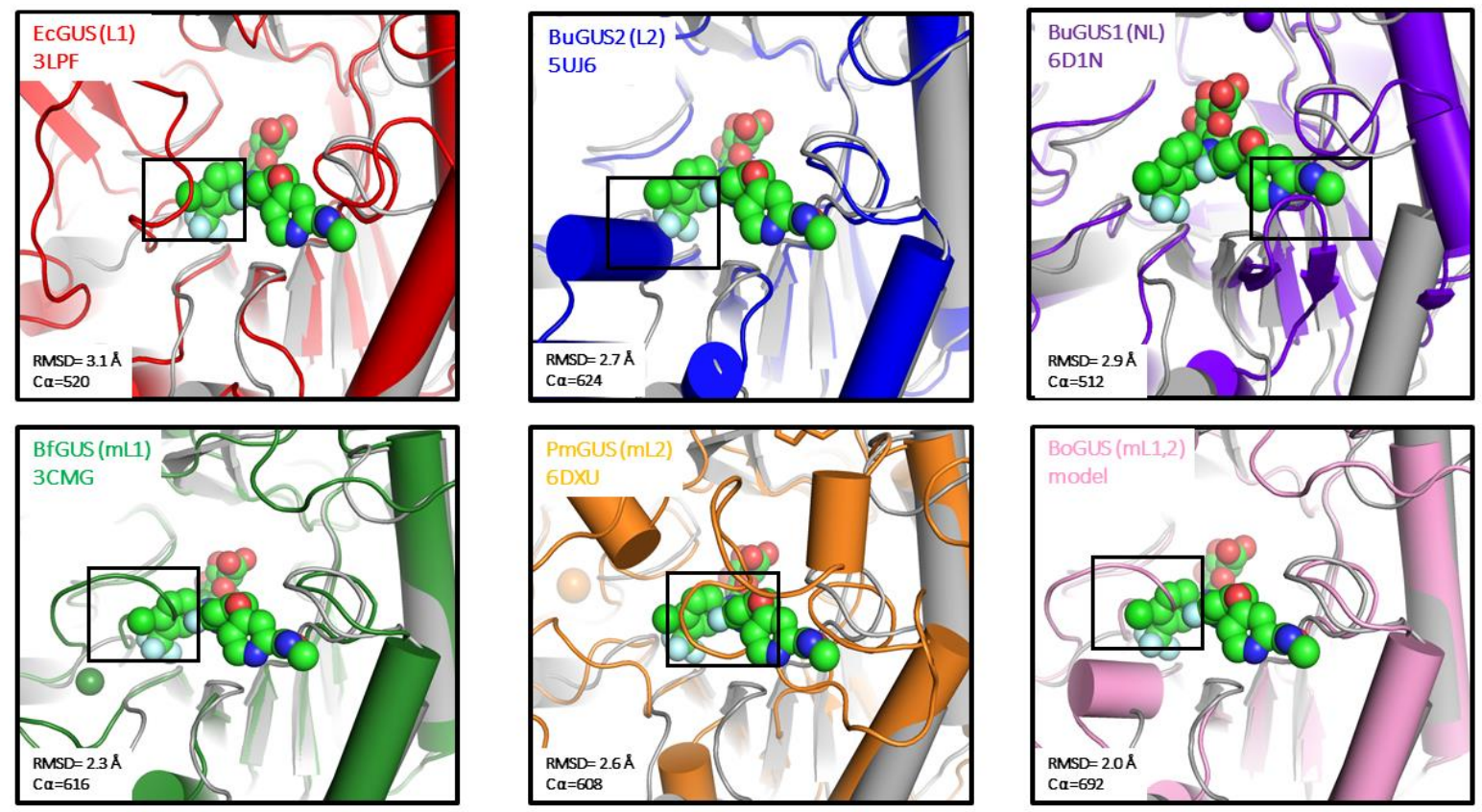

Figure S5. Results of LOPAC HTS. Correlation coefficient plot of duplicate runs of Library of Pharmacologically Active Compounds (LOPAC) screen. From left to right is increasing levels of 
inhibition where hits were considered those that inhibited $100 \%$ in duplicate trials. Most hits were dismissed as non-tractable, but raloxifene was pursued further.

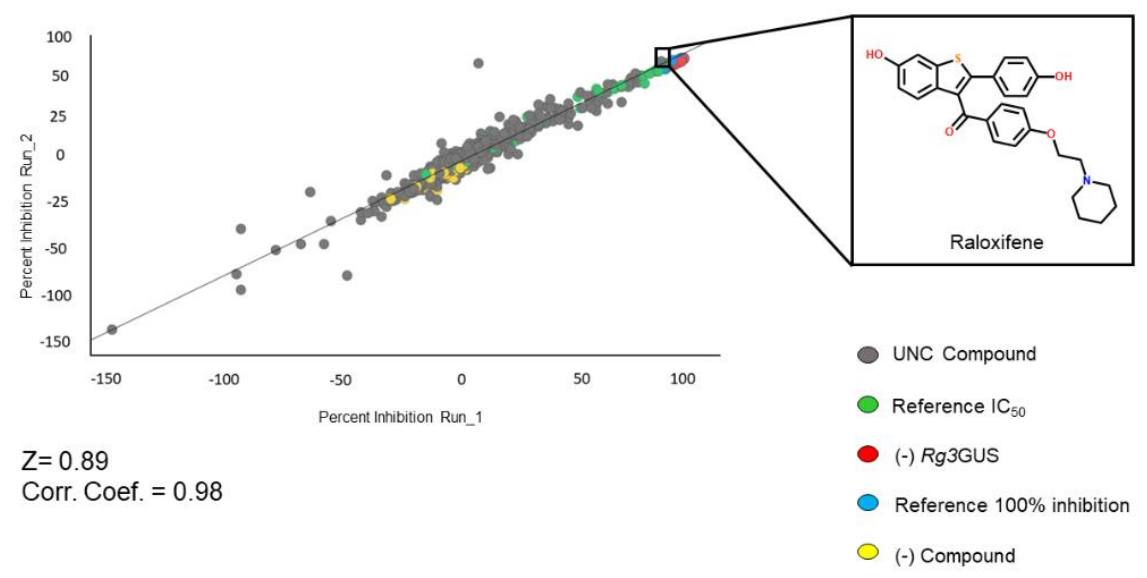

Figure S6. Structures of ER ligands. 12 ER ligands were purchased to determine their inhibition towards GUS enzymes.
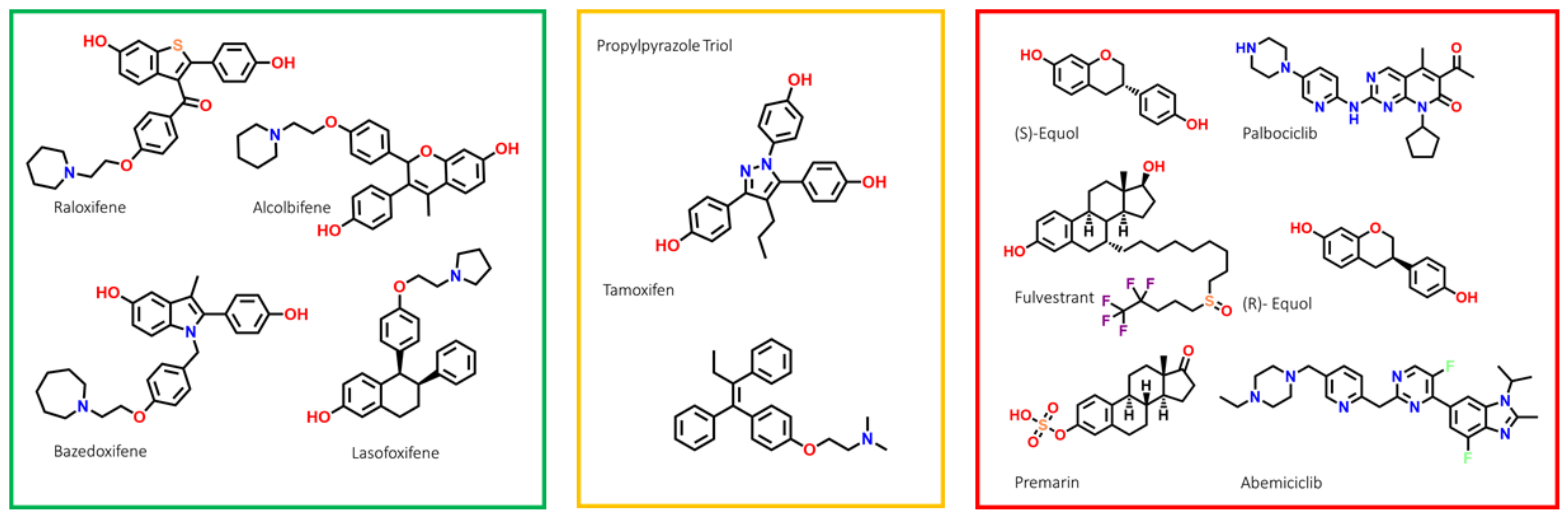

Figure S7. Synthesized Raloxifene Analogs 


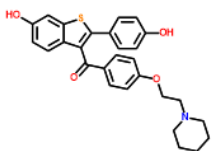

Raloxifene

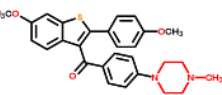

UNC7086

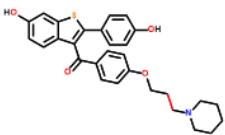

UNC7155

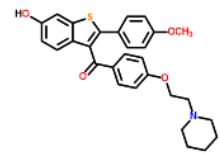

UNC7081

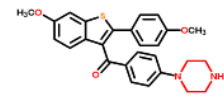

UNC7087

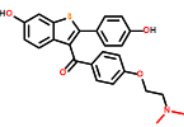

UNC7156

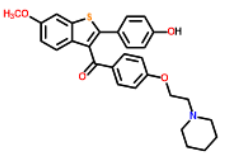

UNC7082

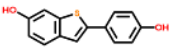

UNC7088

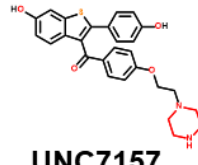

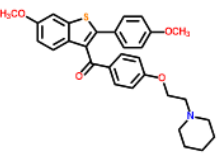

UNC7083

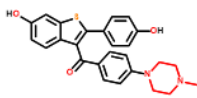

UNC7152

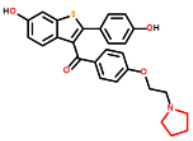

UNC7158

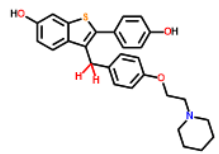

UNC7084

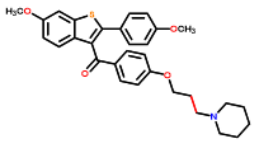

UNC7085

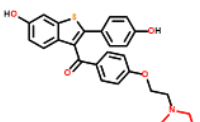

UNC7153

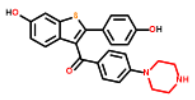

UNC7159
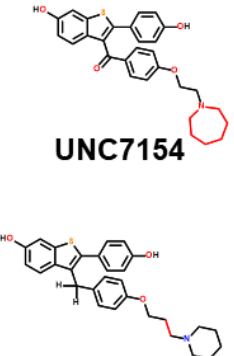

UNC7265

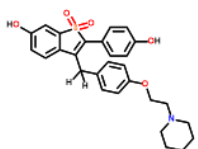

UNC7266

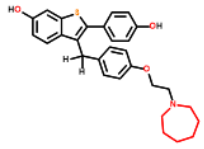

UNC7267

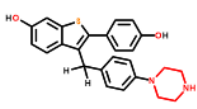

UNC7268

Figure S8. Targeted Inhibition of Regorafenib-Glucuronide processing GUS enzymes. The raloxifene analogs were tested against non-regorafenib-glucuronide reactivating enzymes ( $L 1$, L2, $\mathrm{mL} 1, \mathrm{~mL} 2, \mathrm{~mL} 1,2, \mathrm{NL}$ and Bovine Liver GUS) and show limited inhibition at $100 \mu \mathrm{M}$ inhibitor.

$\%$ Activity of GUS orthologs with addition of $100 \mu \mathrm{M}$ inhibitor

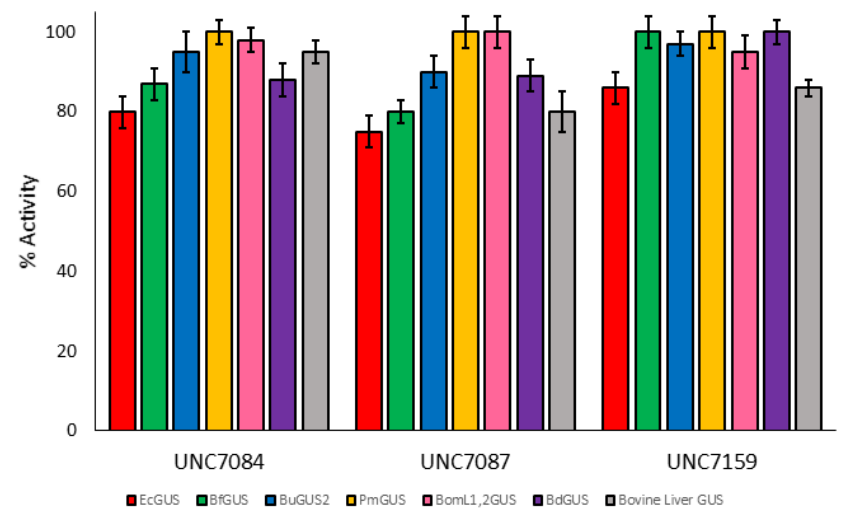

Figure S9. Bacterial cell viability. A. Optical density of $R$. gnavus anaerobically cultured for 24 hours with $10 \mu \mathrm{M}$ of indicated compounds. Where UNC7084 significantly increases OD compared to vehicle (one-way ANOVA Dunnett's test for multiple comparisons) via an undefined mechanism, other raloxifene analogs do not impact $R$. gnavus growth. B. Raloxifene analogs do not alter $R$. gnavus viability when plated on RCM agar. C. Optical density of $E$. coli 
aerobically cultured for 16 hours with $10 \mu \mathrm{M}$ of indicated compounds. Raloxifene analogs do not impact $E$. coli growth. D. Raloxifene analogs do not alter E. coli viability when plated on LB agar.

Ruminococcus gnavus

A

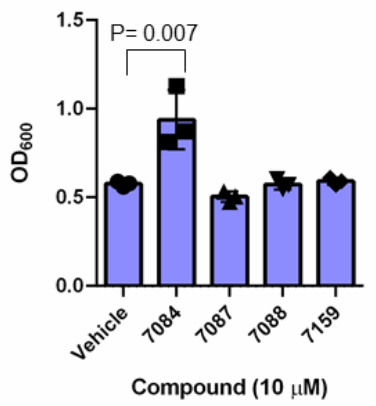

Escherichia coli

C

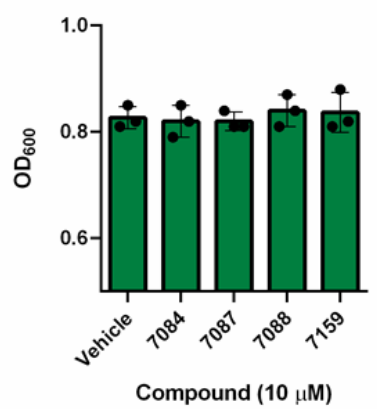

B

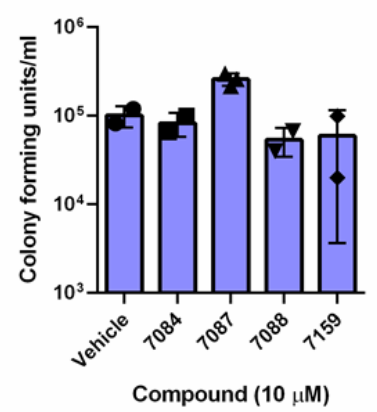

D

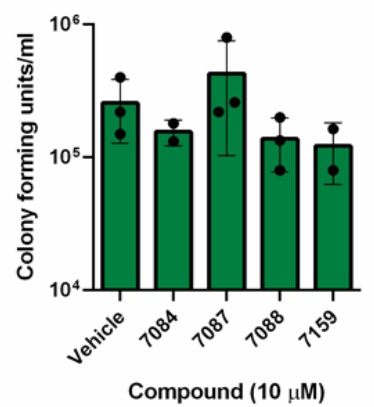

Figure S10. HPLC results of mouse intestinal incubation. A. Representative chromatogram of cecum + regorafenib-glucuronide incubated for 48 hours. B. Representative chromatogram of cecum + regorafenib-glucuronide $+20 \mu \mathrm{M}$ UNC7087 


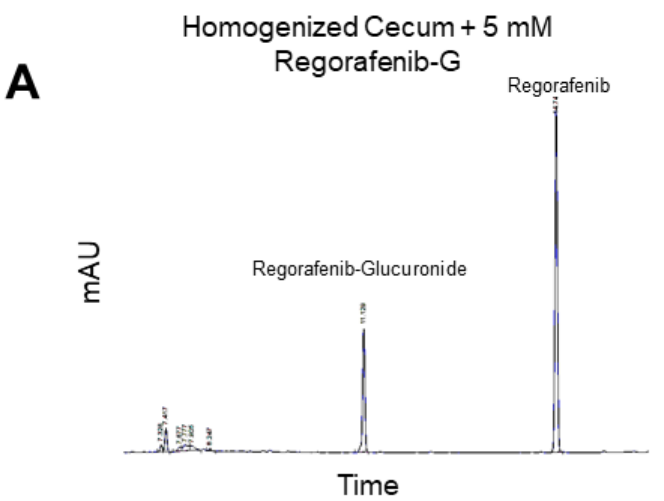

B Homogenized Cecum + 5 mM Regorafenib-G +

$20 \mu \mathrm{M}$ inh UNC7087

Regorafenib-Glucuronide

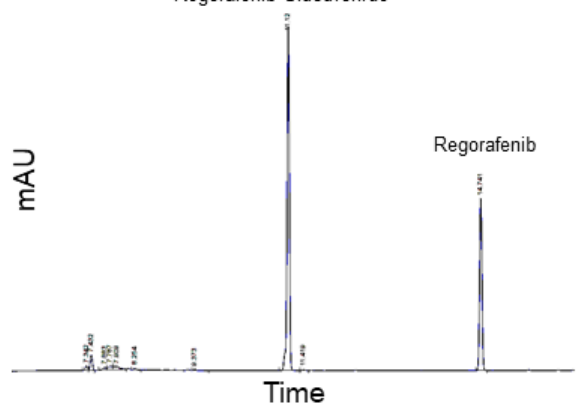

Figure S11. ${ }^{1} \mathrm{H}$ NMR and ${ }^{19} \mathrm{~F}$ NMR of Key Intermediate 1

Key Intermediate
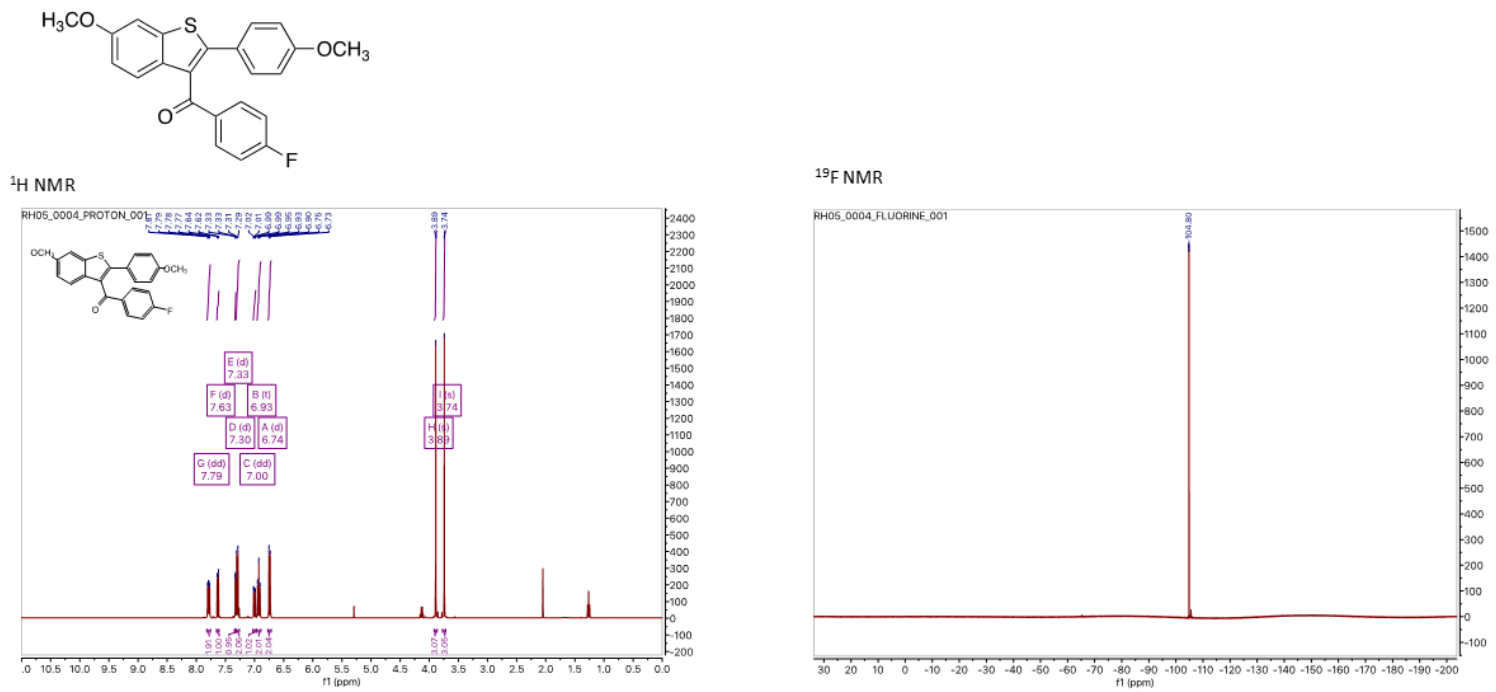

Figure S12. ${ }^{13} \mathrm{C}$ NMR of Key Intermediate 1 
Key Intermediate I

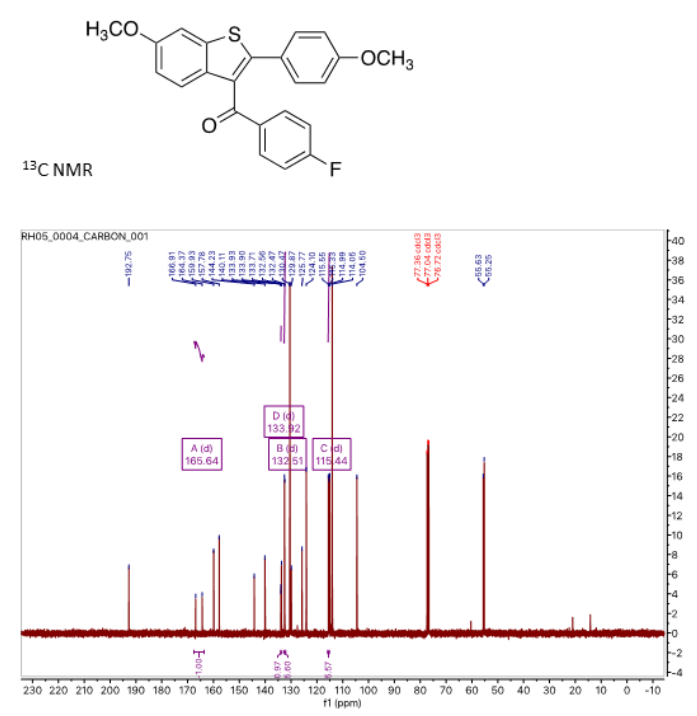

Figure S13. ${ }^{1} \mathrm{H}$ NMR and ${ }^{19} \mathrm{~F}$ NMR of Key Intermediate 2

Key Intermediate II

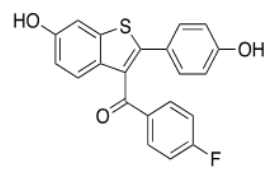

${ }^{1} \mathrm{H}$ NMR
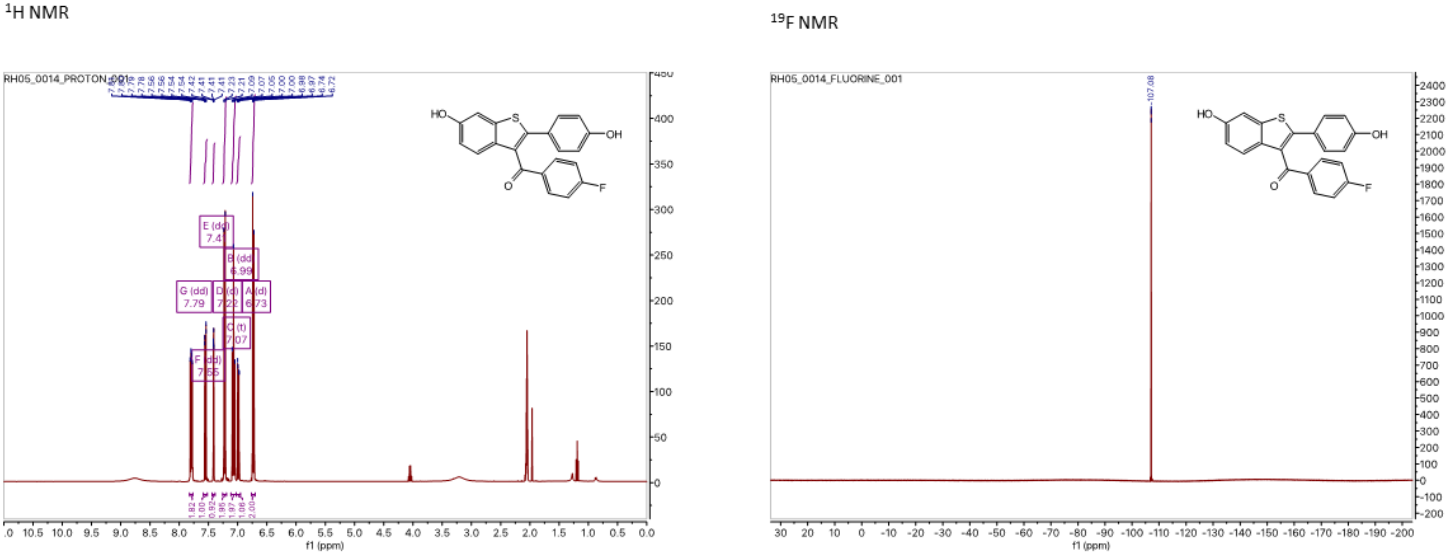

Figure S14. ${ }^{13} \mathrm{C}$ NMR of Key Intermediate 2 
Key Intermediate II

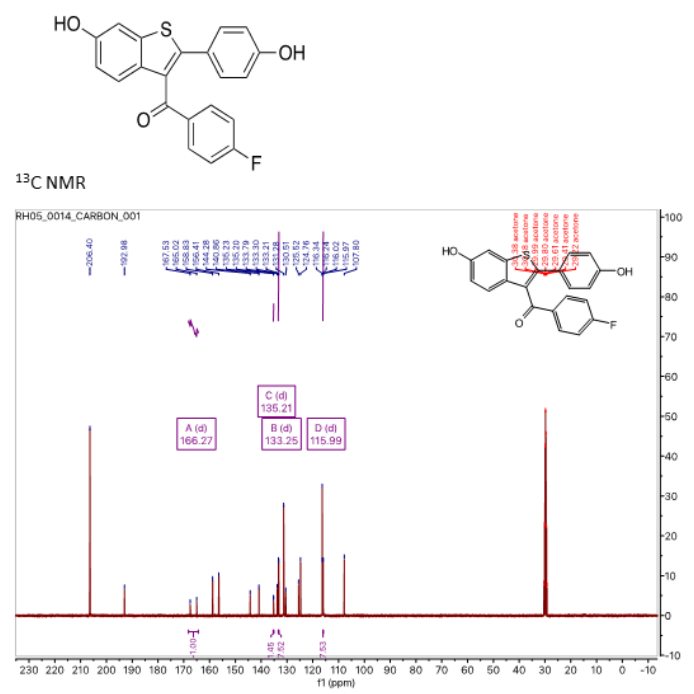

Figure S15. ${ }^{1} \mathrm{H}$ NMR and LCMS of UNC7081

UNC7081

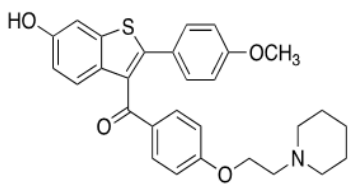

${ }^{1} \mathrm{HNMR}$
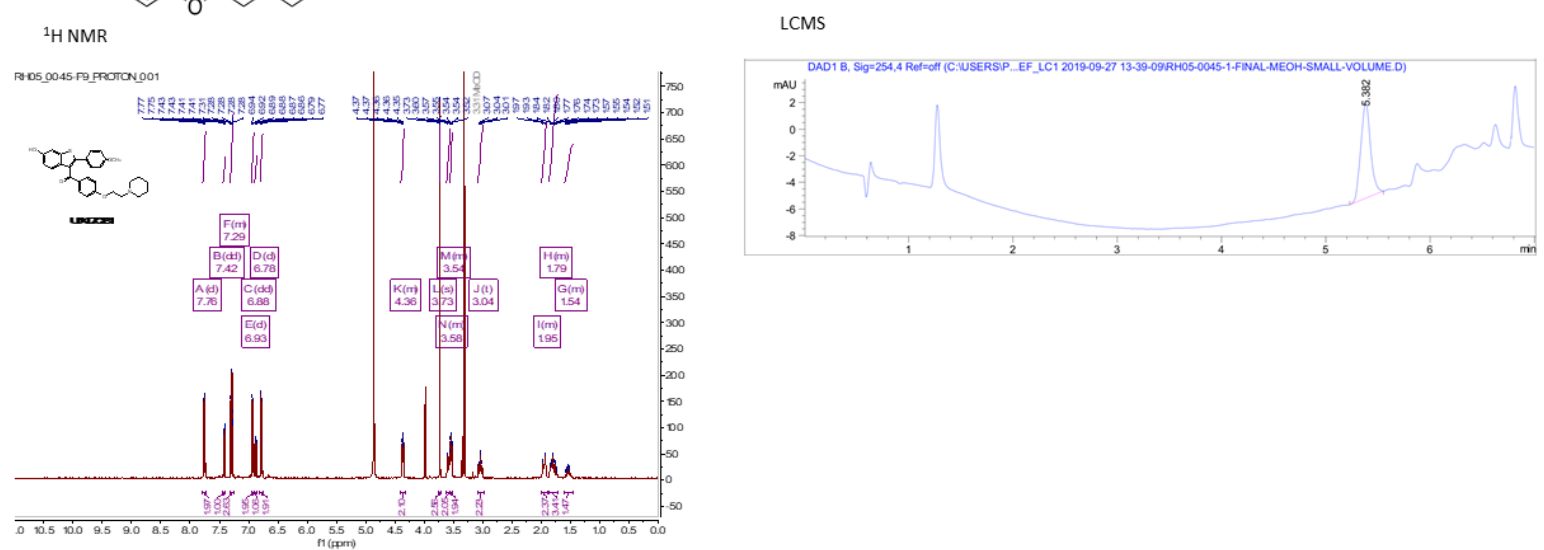

Figure S16. ${ }^{1} \mathrm{H}$ NMR and LCMS of UNC7082 

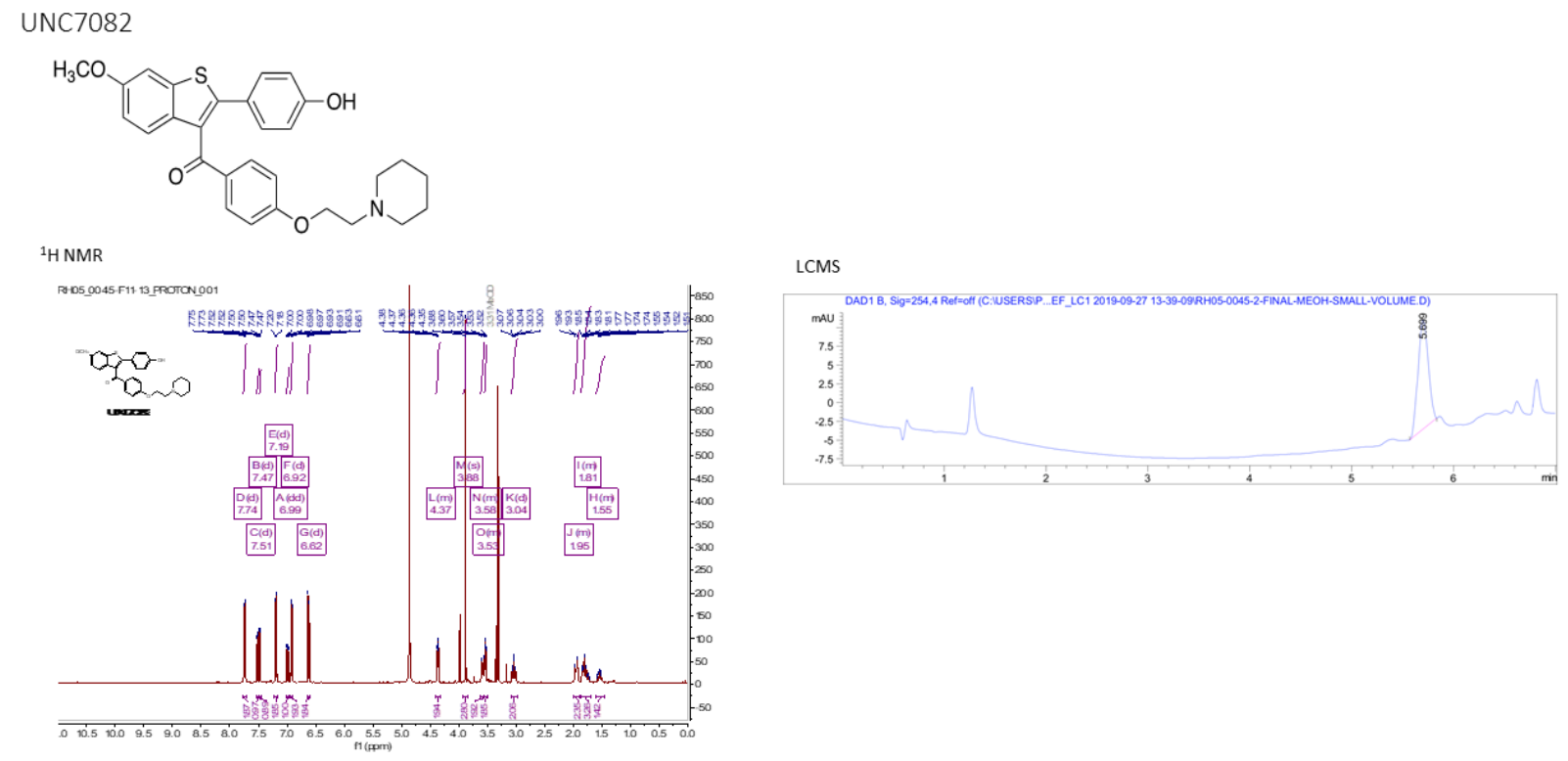

Figure S17. ${ }^{1} \mathrm{H}$ NMR and LCMS of UNC7083
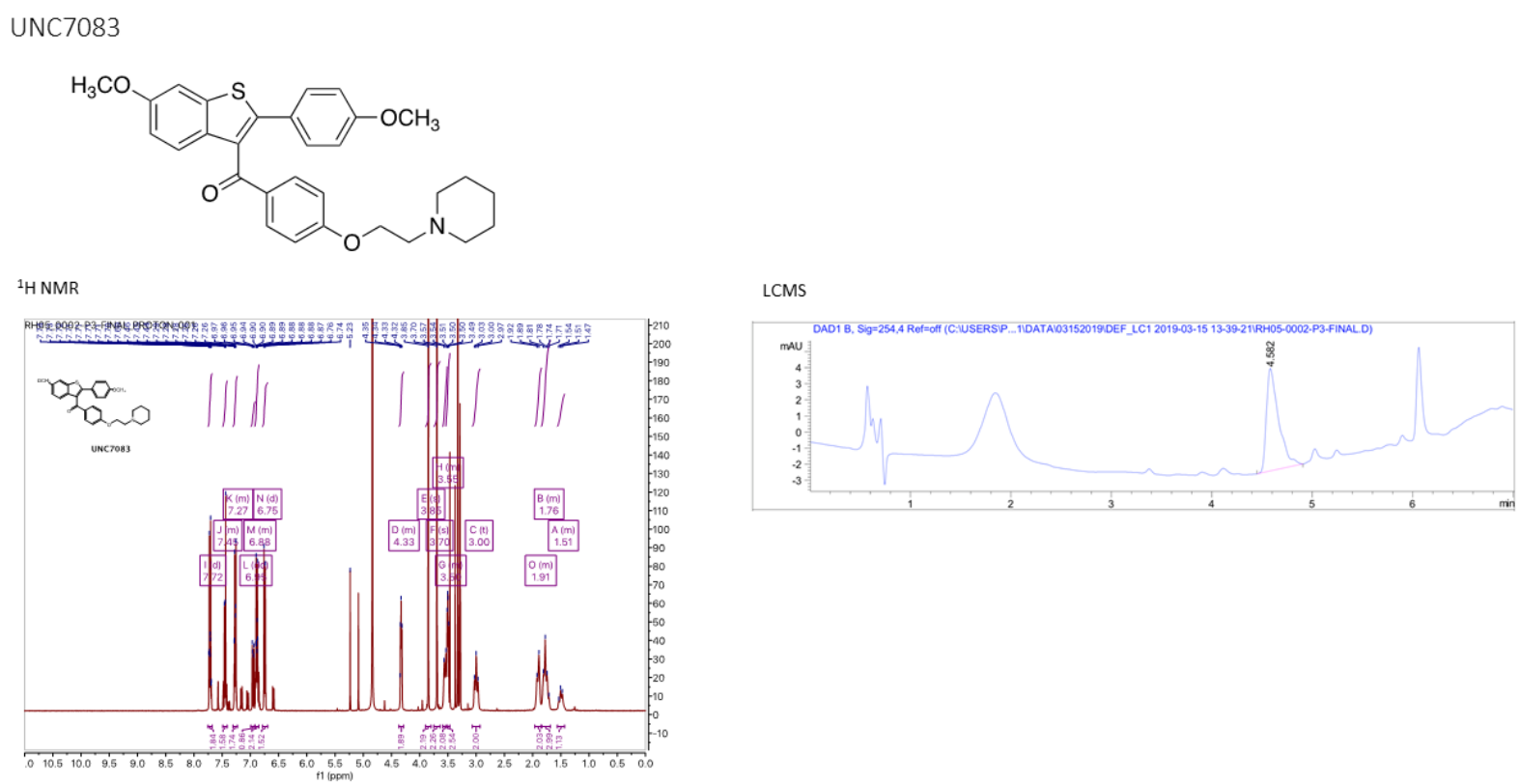

Figure S18. ${ }^{1} \mathrm{H}$ NMR and LCMS of UNC7084 


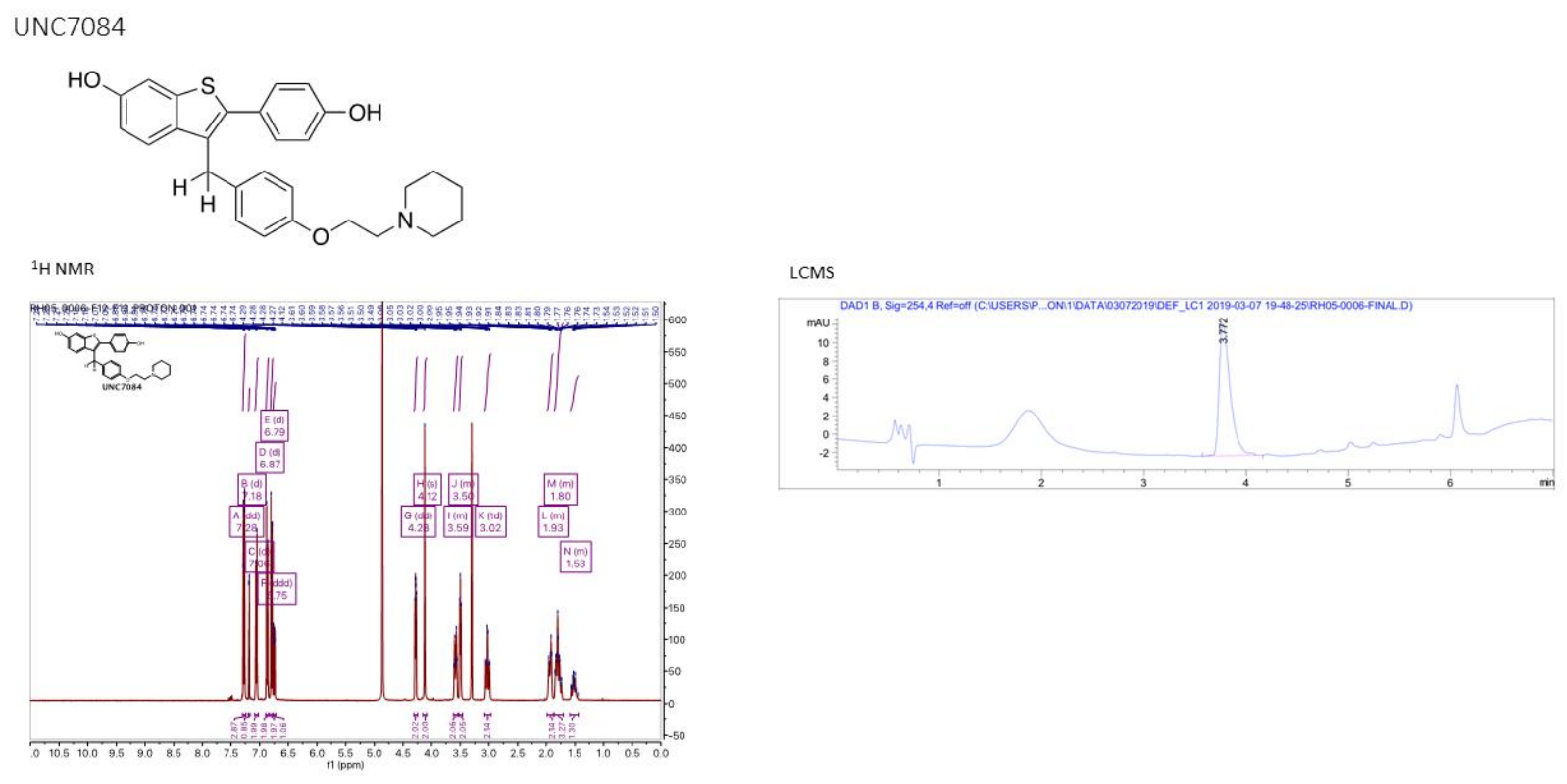

Figure S19. FTMS + p ESI full MS of UNC7084

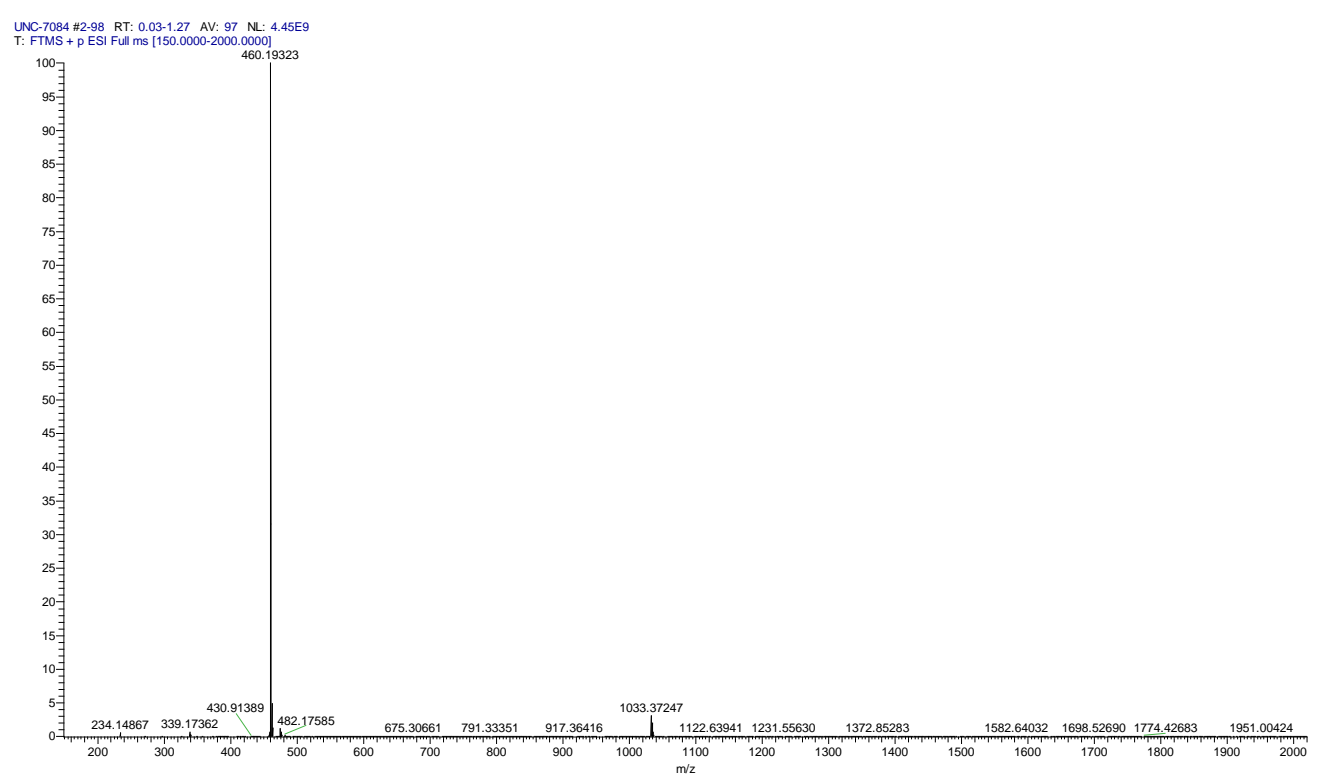

\section{Full Scan}




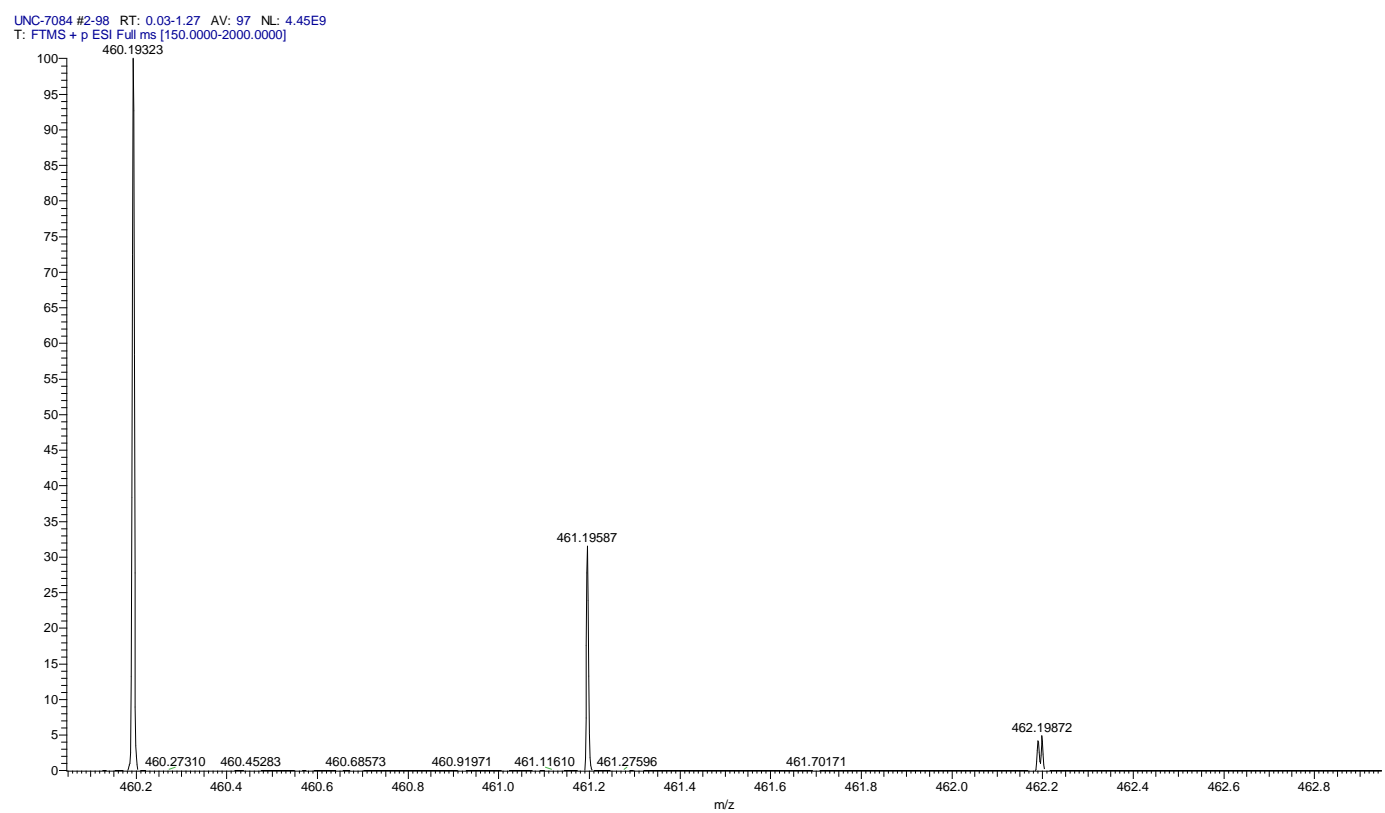

Zoom Inset

$m / z: 460.19323$

mass error $=-1.9 \mathrm{ppm}$

Assigned chemical formula: C28H30NO3S [M] ${ }^{+}$

Assessment: The observed mass and isotope peaks confirm the chemical formula assigned above. A sulfur isotope peak was observed at $+2 \mathrm{Da}$ at approximately $4 \%$ of the $[\mathrm{M}]^{+} \mathrm{m} / \mathrm{z}$ peak. A sodium adduct $[\mathrm{M}+\mathrm{Na}]^{+}$was observed at $482.17275 \mathrm{~m} / \mathrm{z}$ as well as a $[2 \mathrm{M}+\mathrm{Na}]^{+}$adduct at $1033.37247 \mathrm{~m} / \mathrm{z}$.

Figure S20. ${ }^{1} \mathrm{H}$ NMR and LCMS of UNC7085 


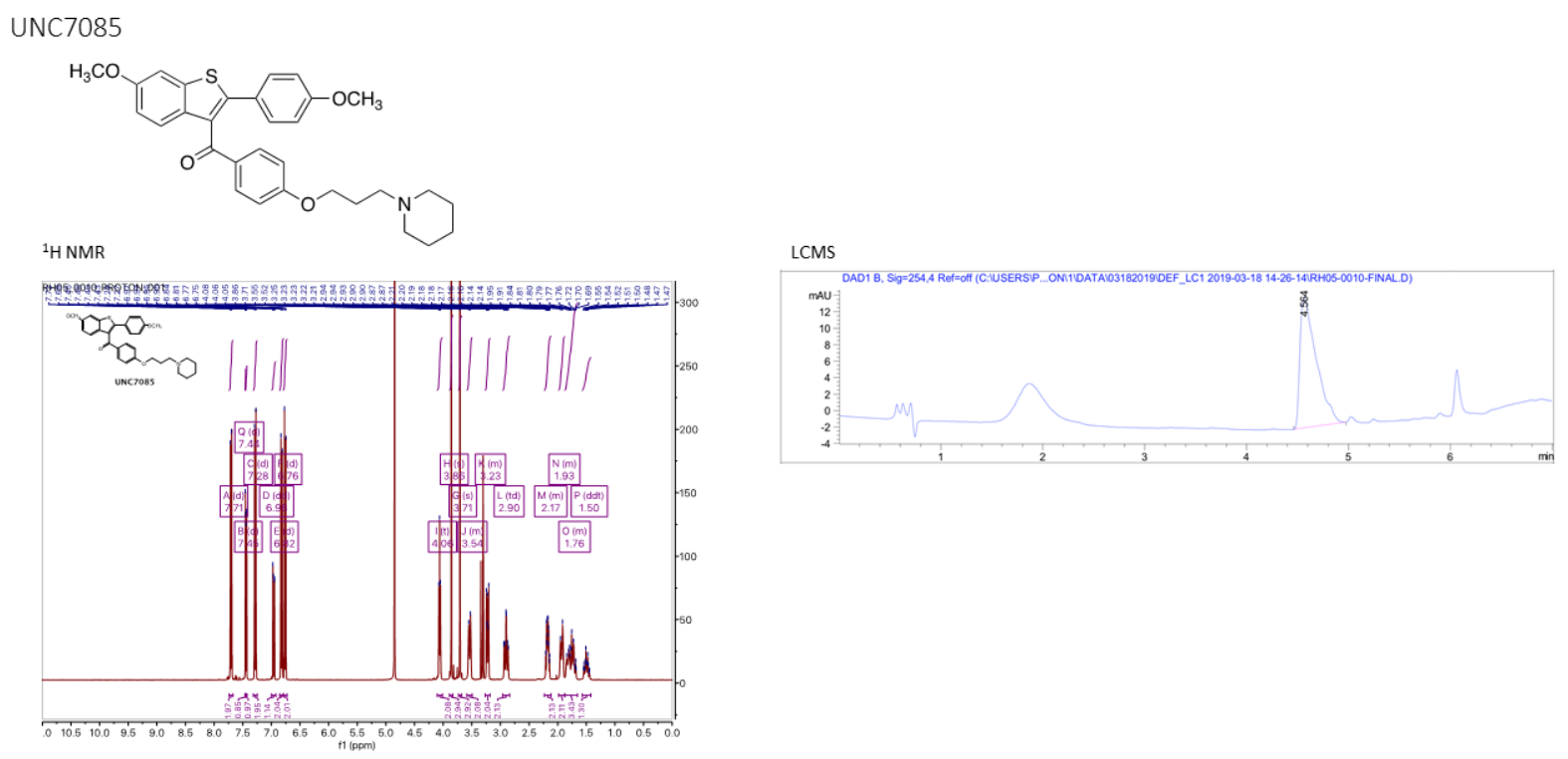

Figure S21. ${ }^{1} \mathrm{H}$ NMR and LCMS of UNC7086

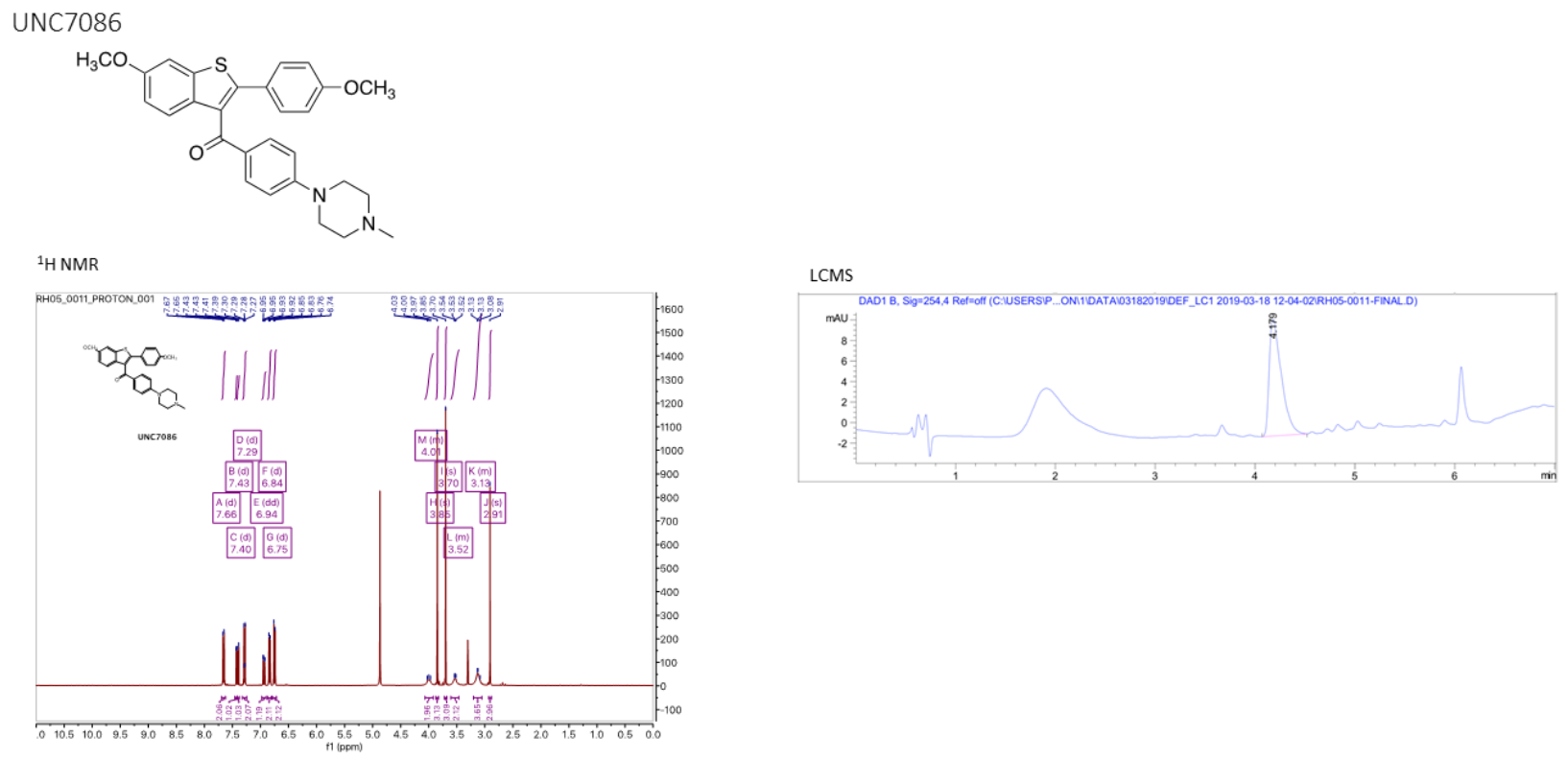

Figure S22. ${ }^{1} \mathrm{H}$ NMR and LCMS of UNC7087 
UNC7087
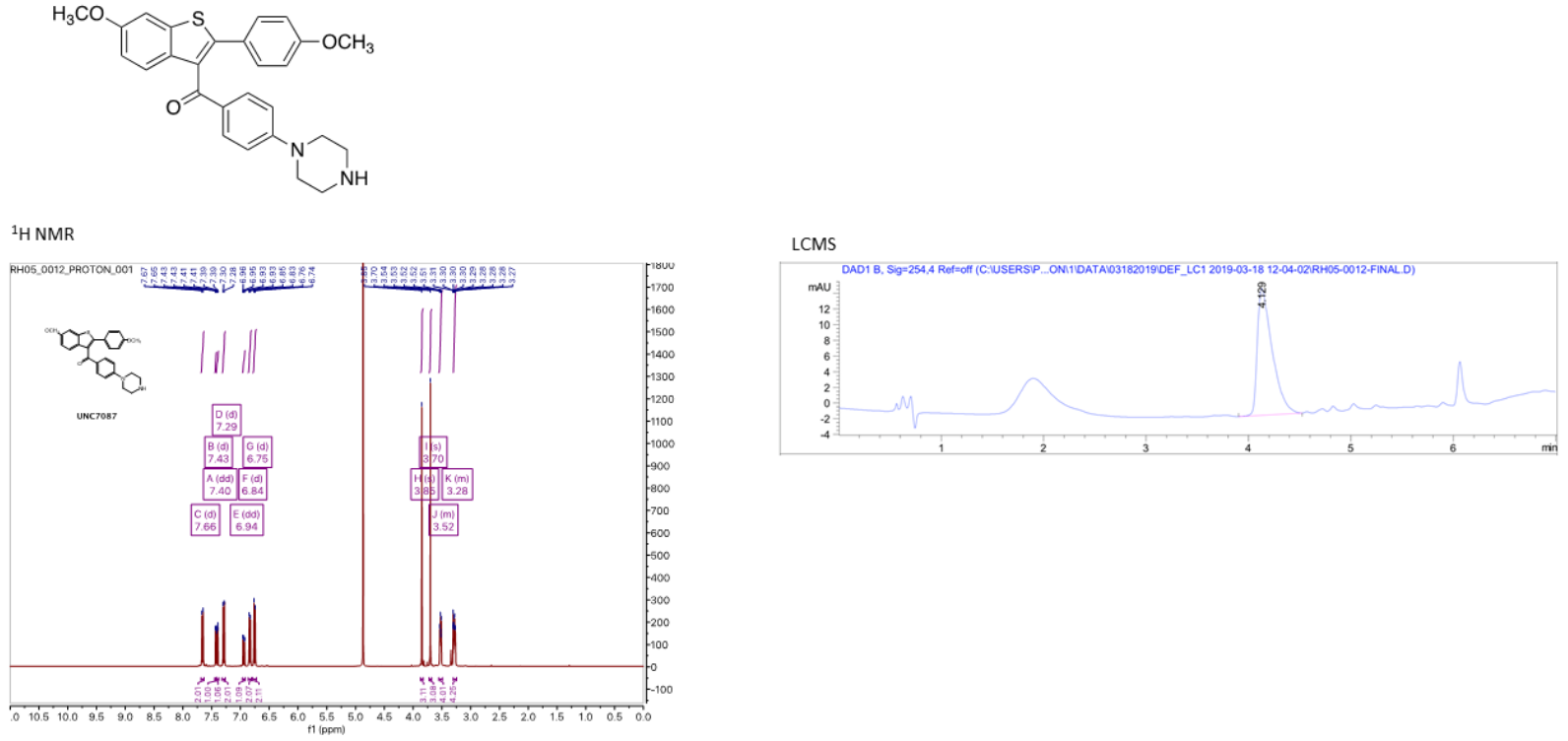

Figure S23. FTMS + p ESI full MS of UNC7087

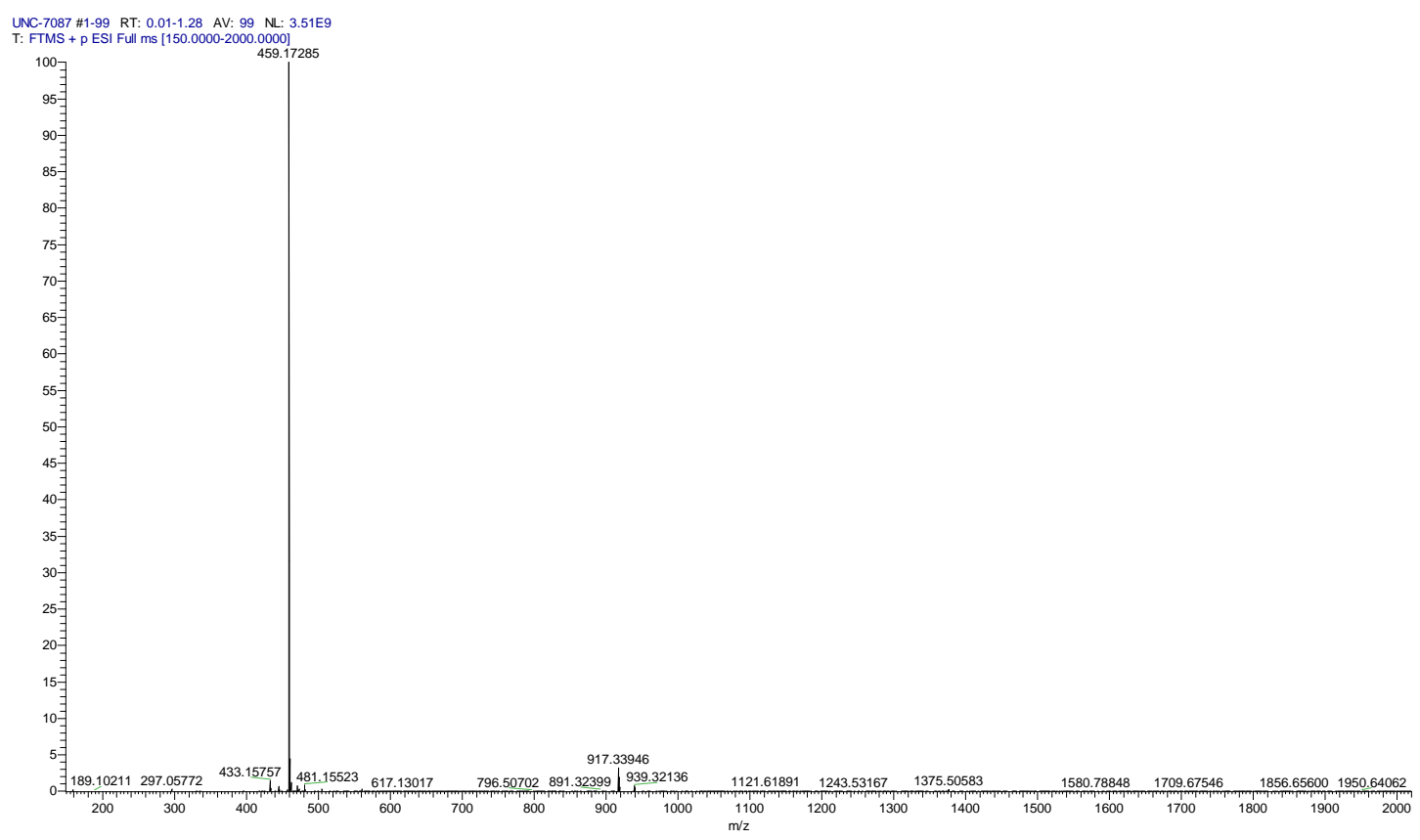

Full Scan 


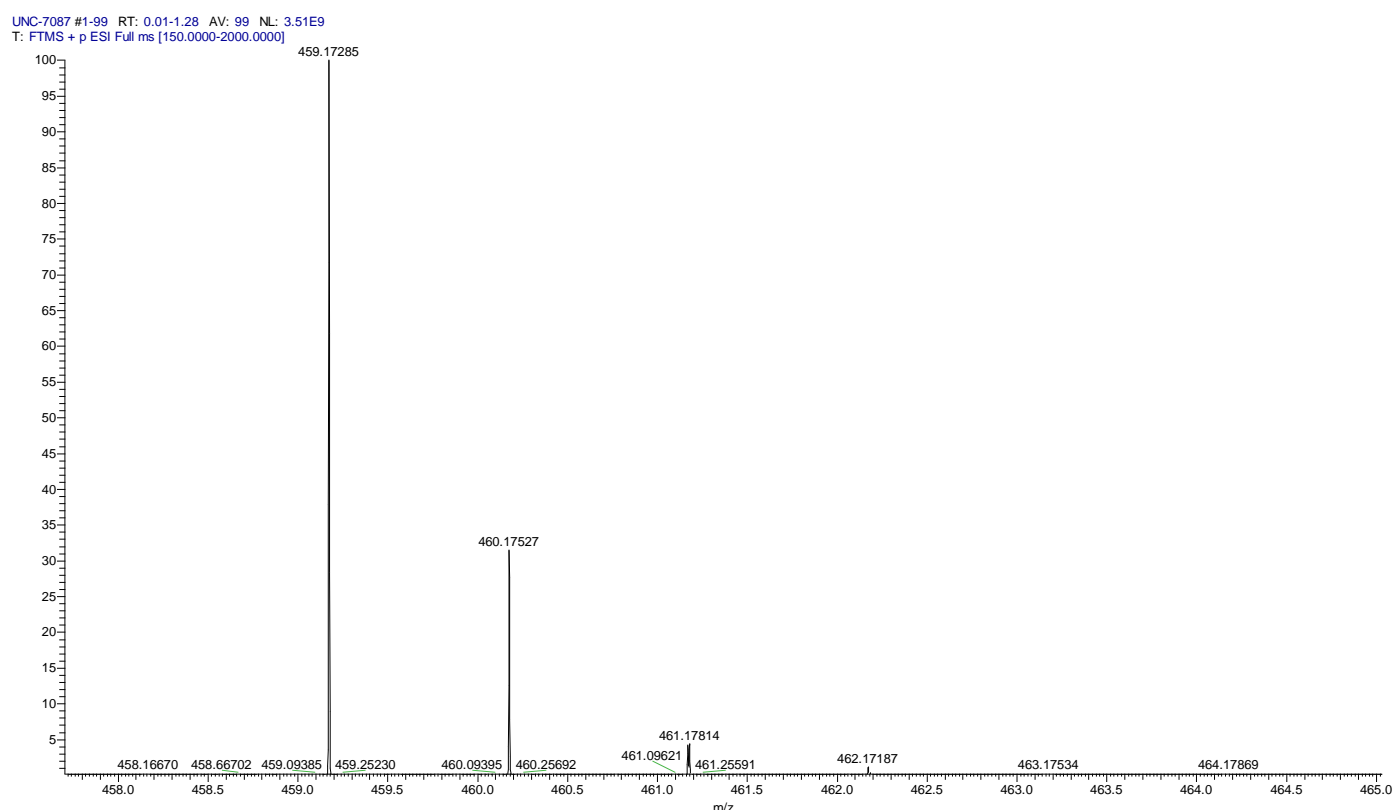

\section{Zoom Inset}

$m / z: 459.17285$

mass error $=-1.8 \mathrm{ppm}$

Assigned chemical formula: C27H27N2O3S [M] ${ }^{+}$

Assessment: The observed mass and isotope peaks confirm the chemical formula assigned above. A sulfur isotope peak was observed at $+2 \mathrm{Da}$ at approximately $4 \%$ of the $[\mathrm{M}]^{+} \mathrm{m} / \mathrm{z}$ peak. A sodium adduct $[\mathrm{M}+\mathrm{Na}]^{+}$was observed at $481.15523 \mathrm{~m} / \mathrm{z}$ as well as a $[2 \mathrm{M}+\mathrm{H}]^{+}$adduct at $917.33946 \mathrm{~m} / \mathrm{z}$.

Figure S24. ${ }^{1} \mathrm{H}$ NMR and LCMS of UNC7088 
UNC7088
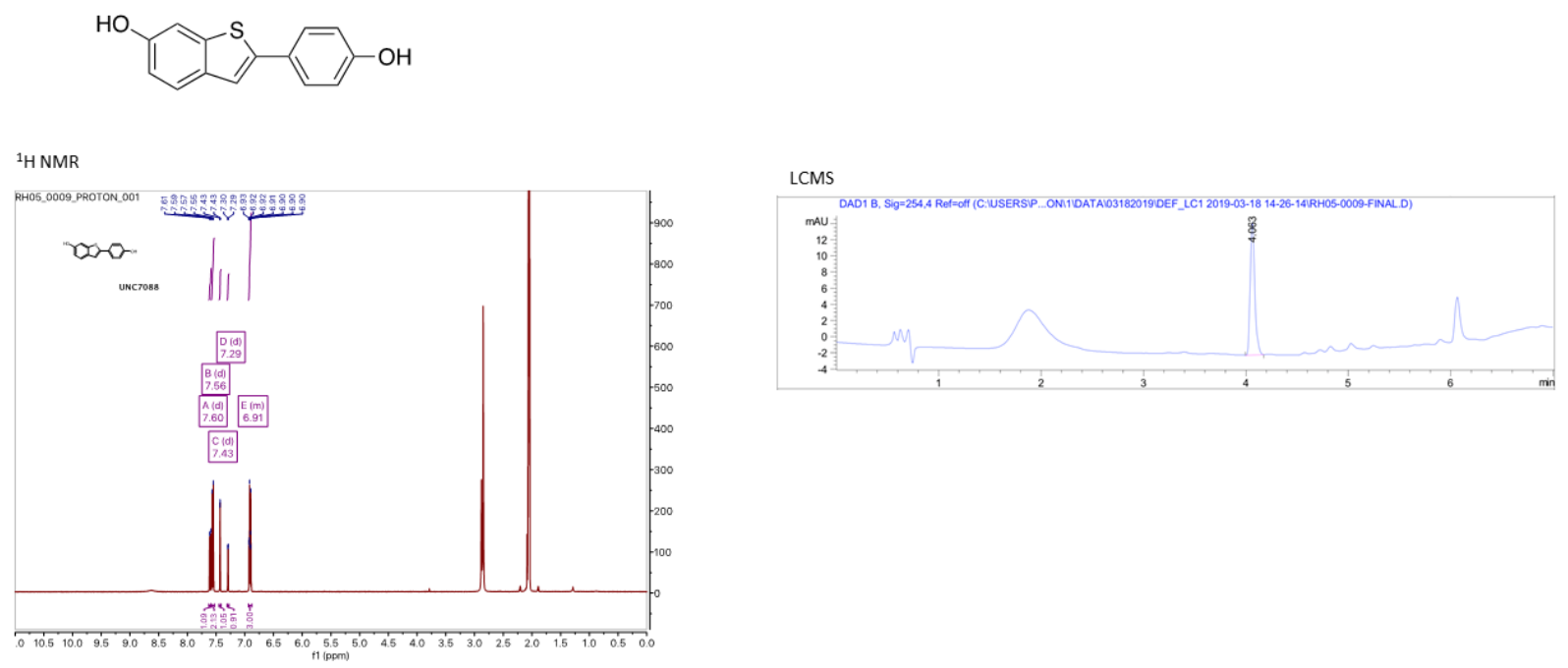

Figure S25. FTMS + p ESI full MS of UNC7088

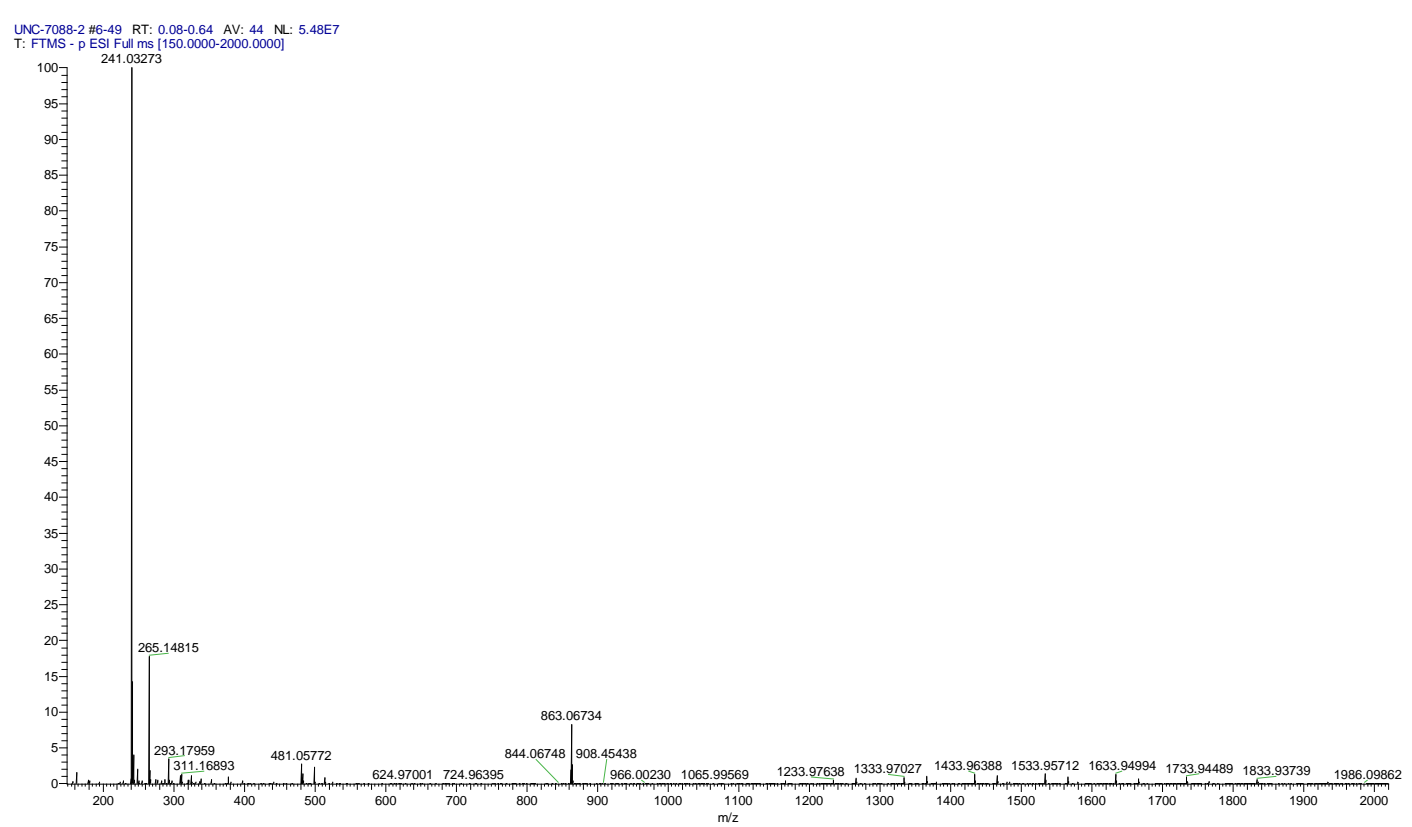

Full Scan 


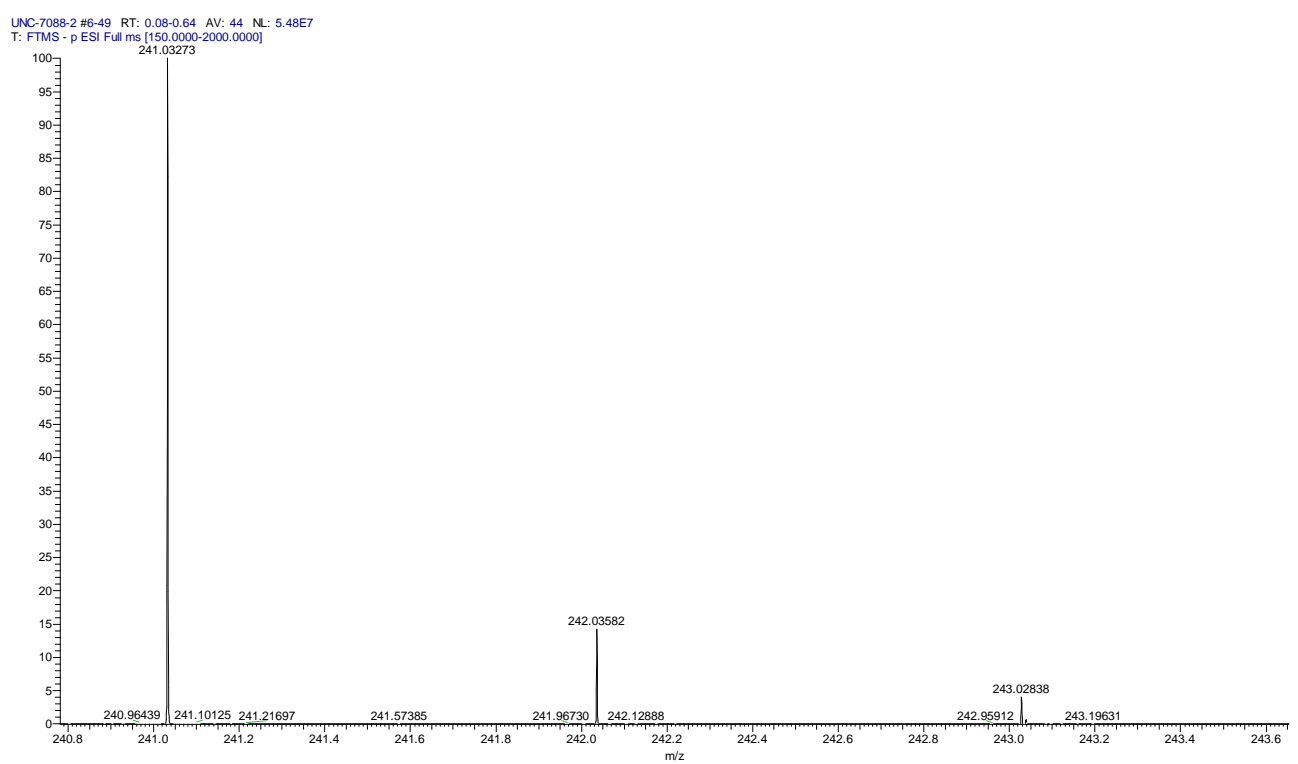

\section{Zoom Inset}

$m / z=241.03273$

mass error $=-0.6 \mathrm{ppm}$

Assigned Chemical Formula: C14H9O2S [M-H]

Assessment: The observed mass and isotope peaks confirm the chemical formula assigned above. A dimer [2M-H] was observed at $481.05772 \mathrm{~m} / \mathrm{z}$. A sulfur isotope peak was observed at

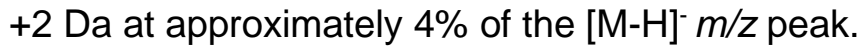

Figure S26. ${ }^{1} \mathrm{H}$ NMR and LCMS of UNC7152 


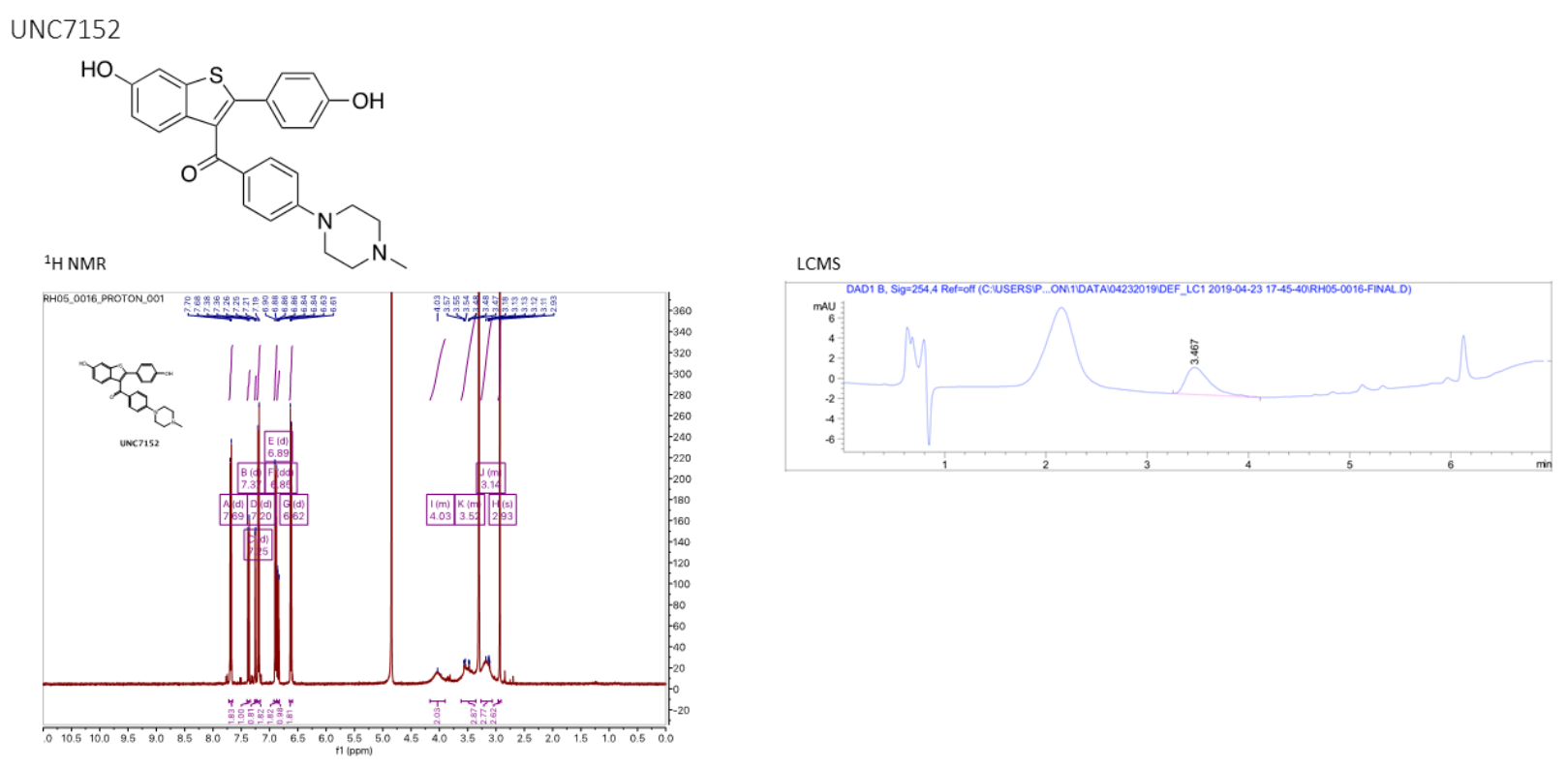

Figure S27. ${ }^{1} \mathrm{H}$ NMR and LCMS of UNC7153

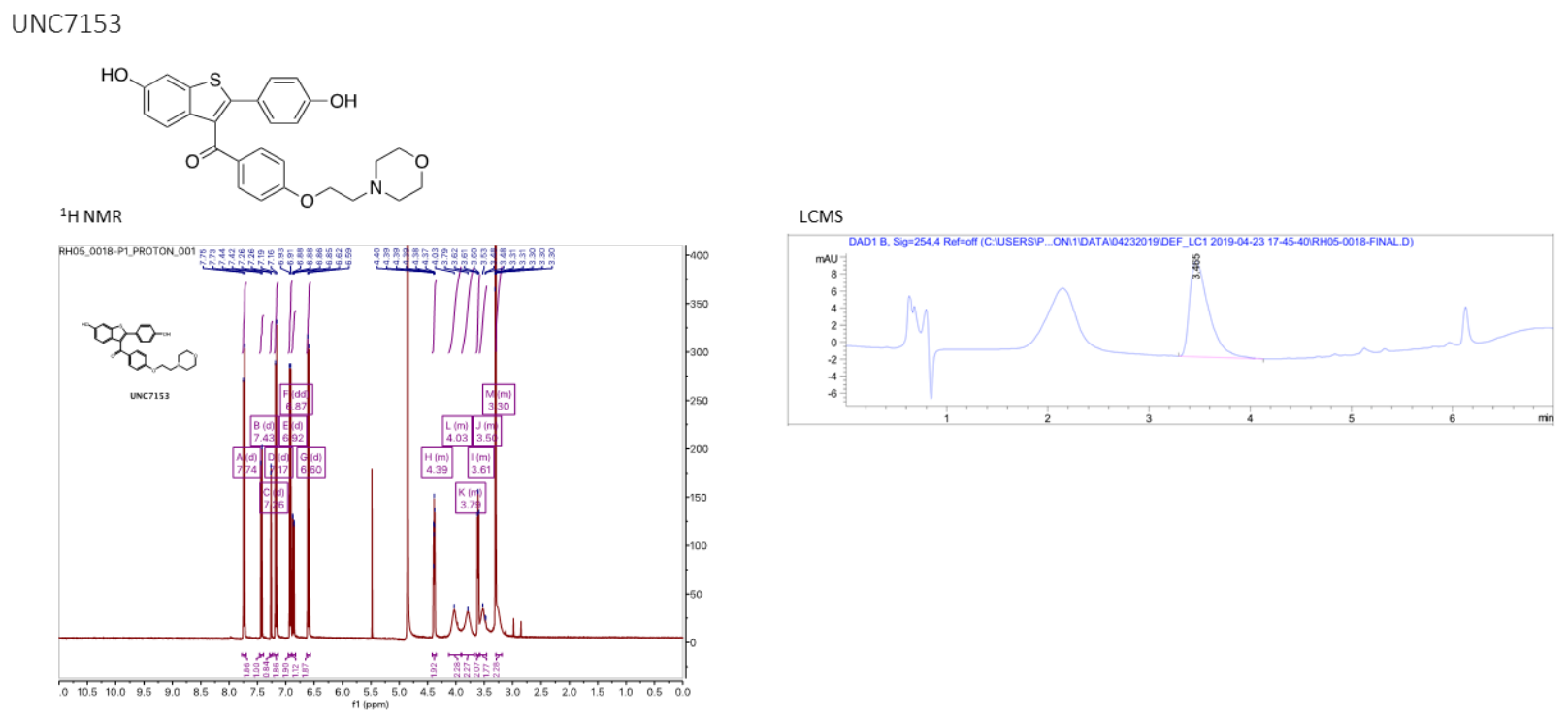

Figure S28. ${ }^{1} \mathrm{H}$ NMR and LCMS of UNC7154 

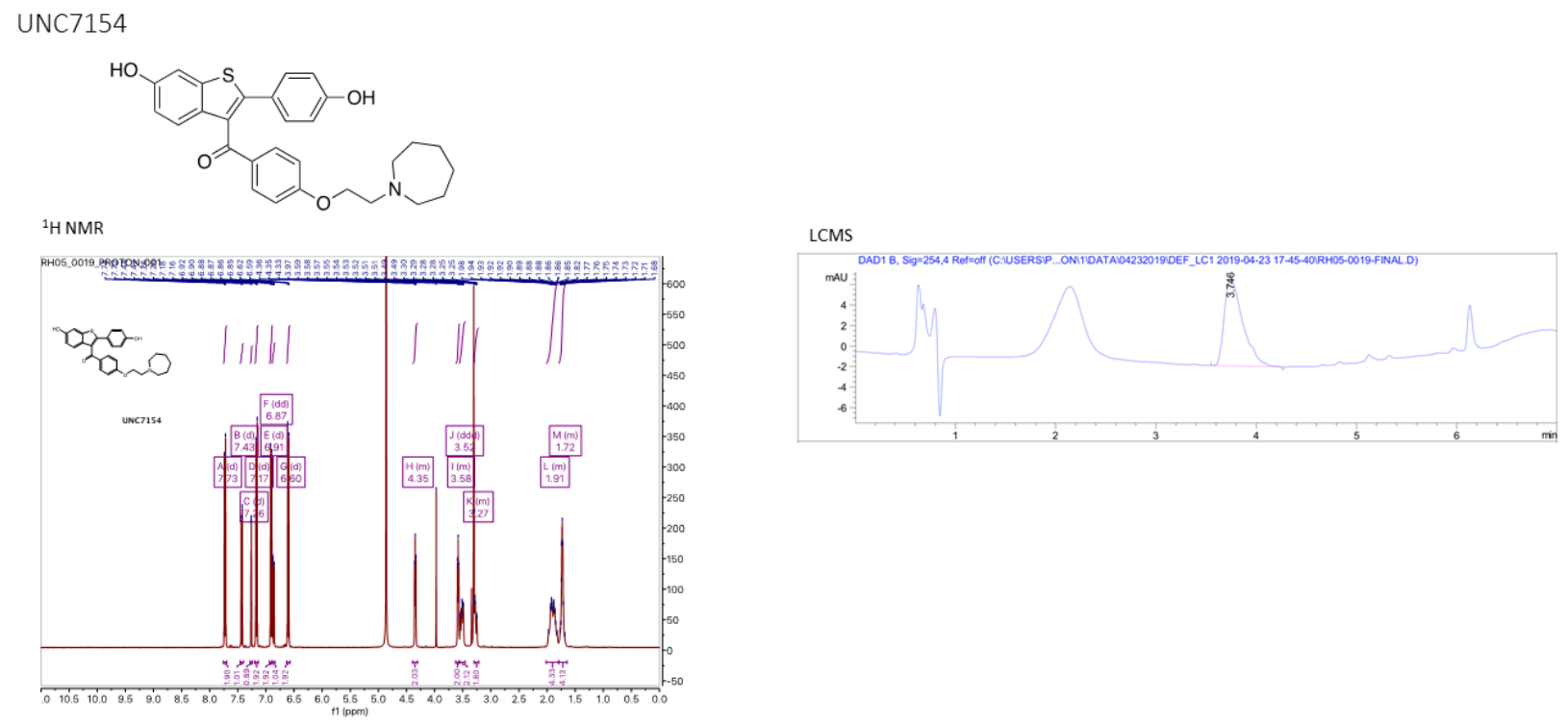

Figure S29. ${ }^{1} \mathrm{H}$ NMR and LCMS of UNC7155
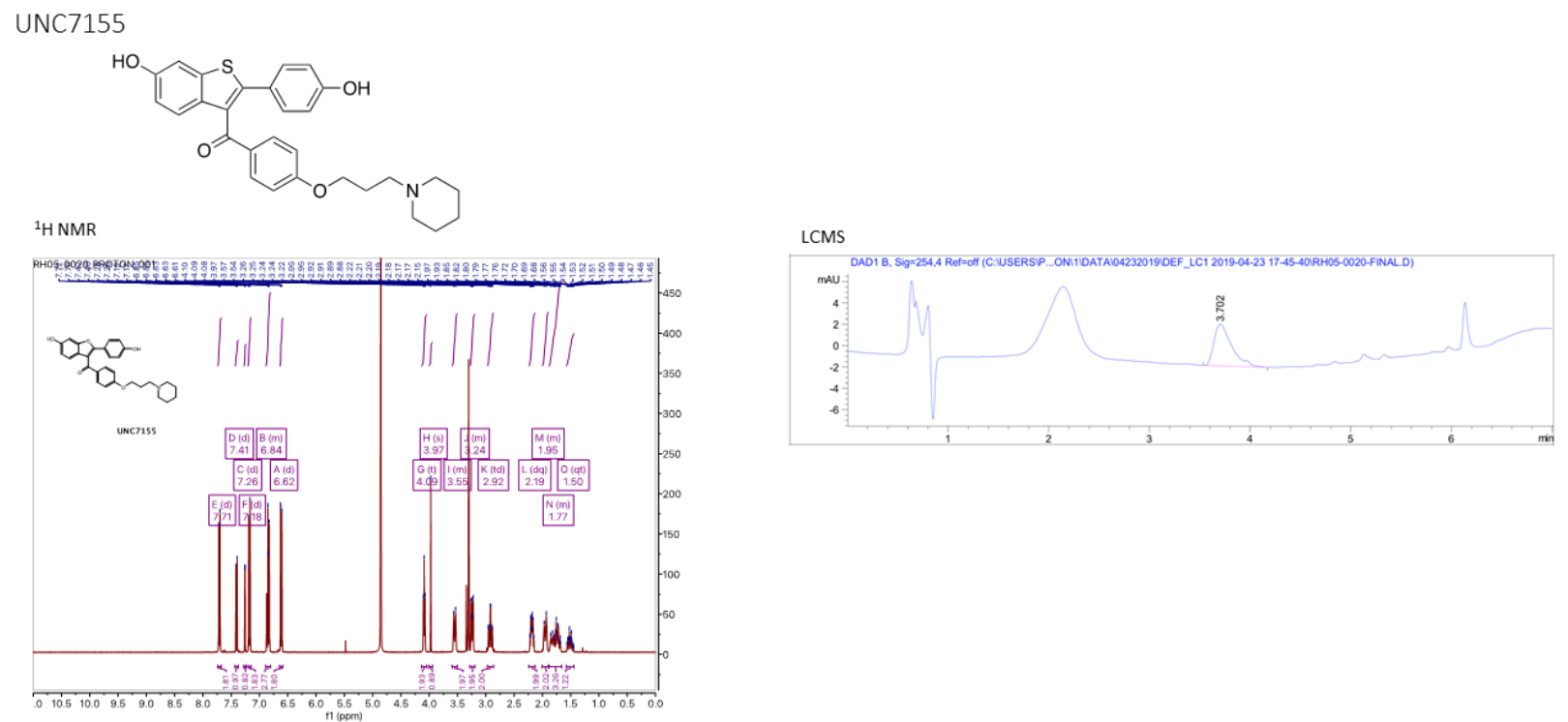

Figure S30. ${ }^{1} \mathrm{H}$ NMR and LCMS of UNC7156 
UNC7156
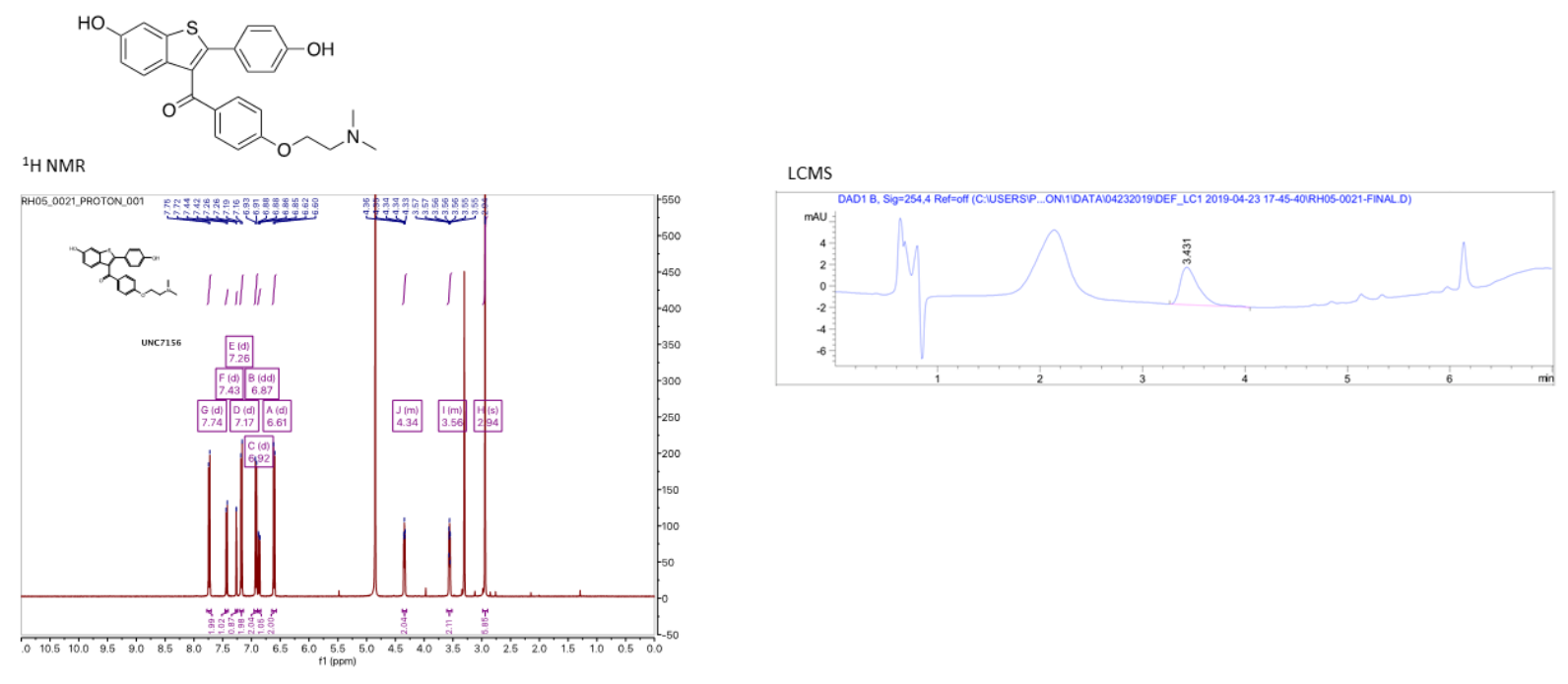

Figure S31. ${ }^{1} \mathrm{H}$ NMR and LCMS of UNC7157

UNC7157
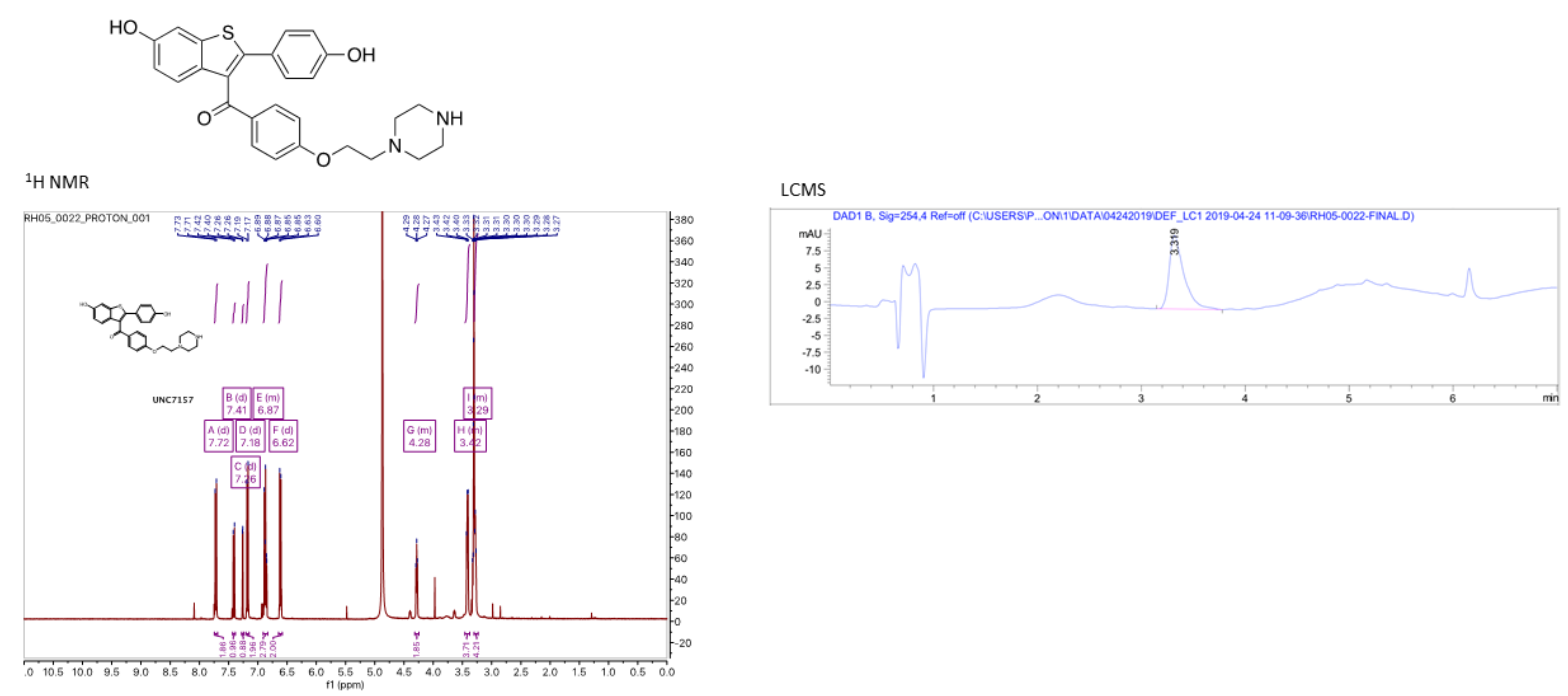

Figure S32. ${ }^{1} \mathrm{H}$ NMR and LCMS of UNC7158 


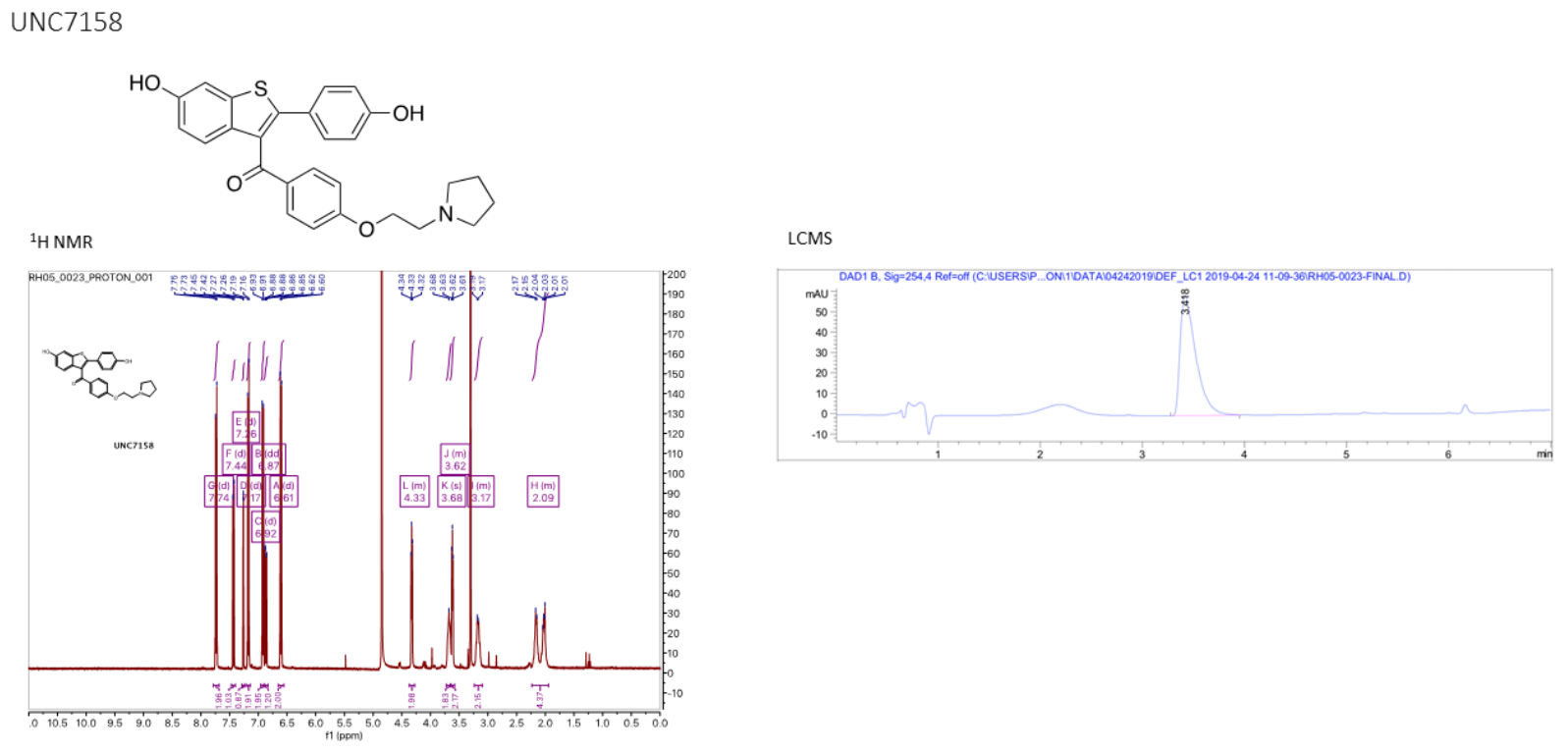

Figure S33. ${ }^{1} \mathrm{H}$ NMR and LCMS of UNC7159

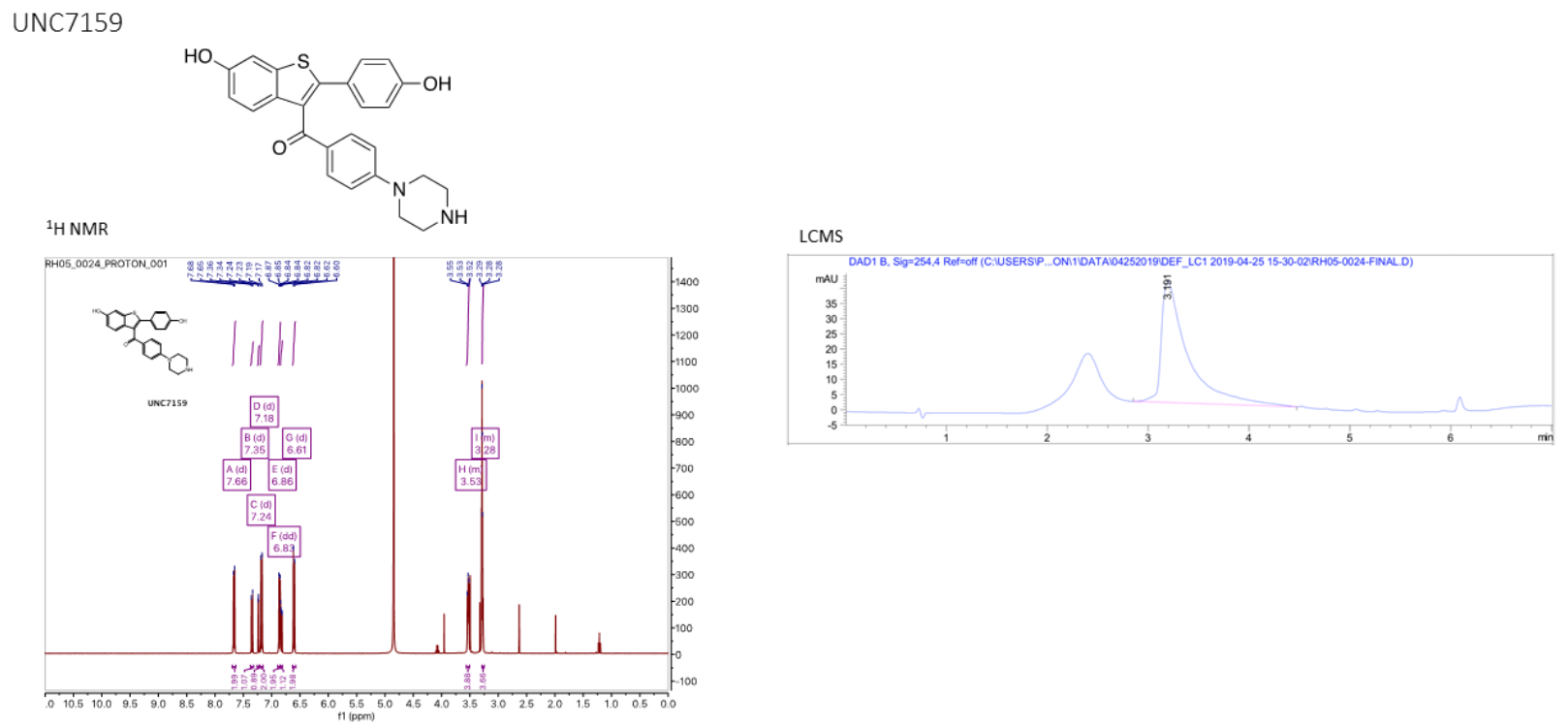

Figure S34. FTMS + p ESI full MS of UNC7159 


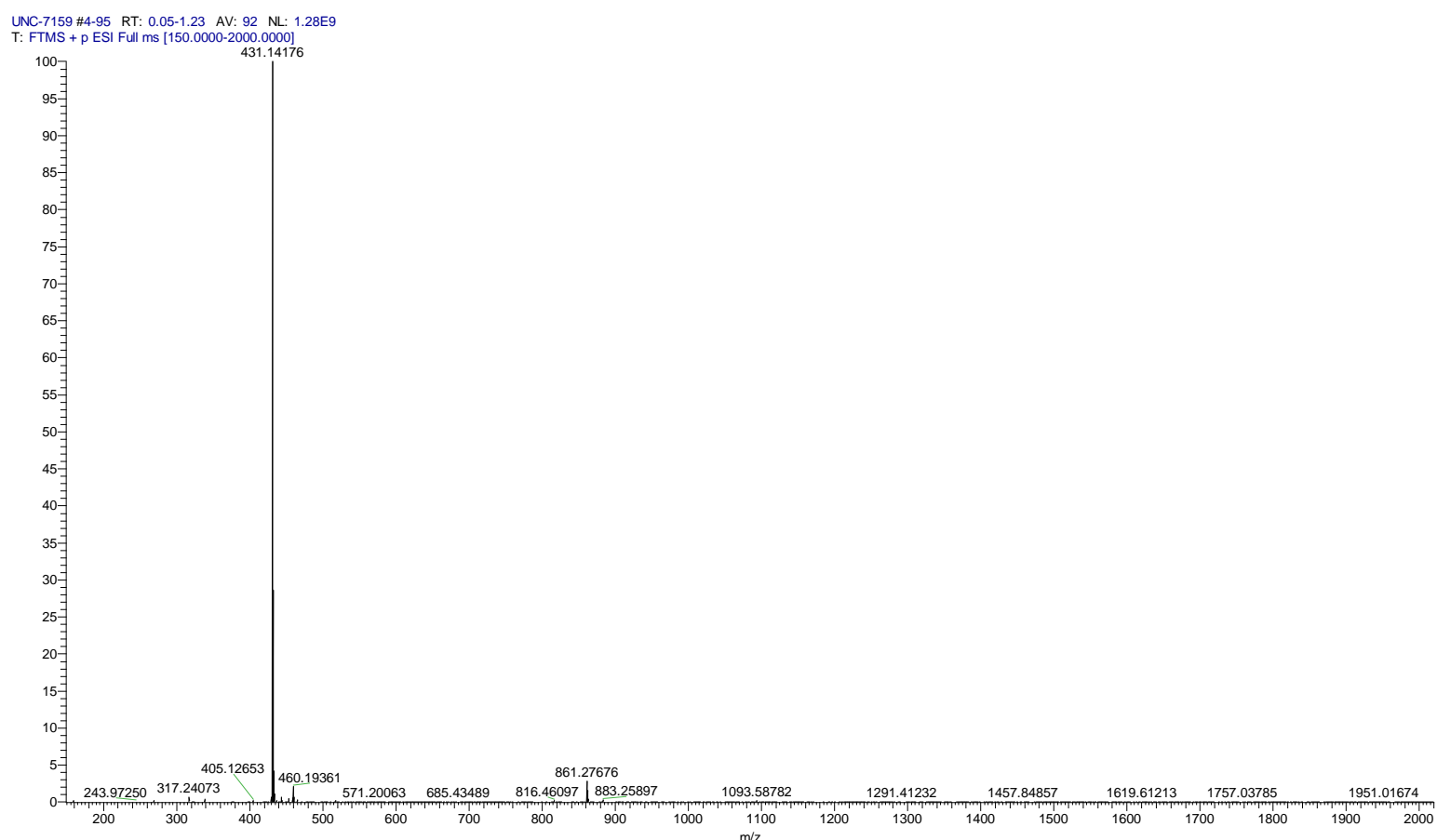

\section{Full Scan}

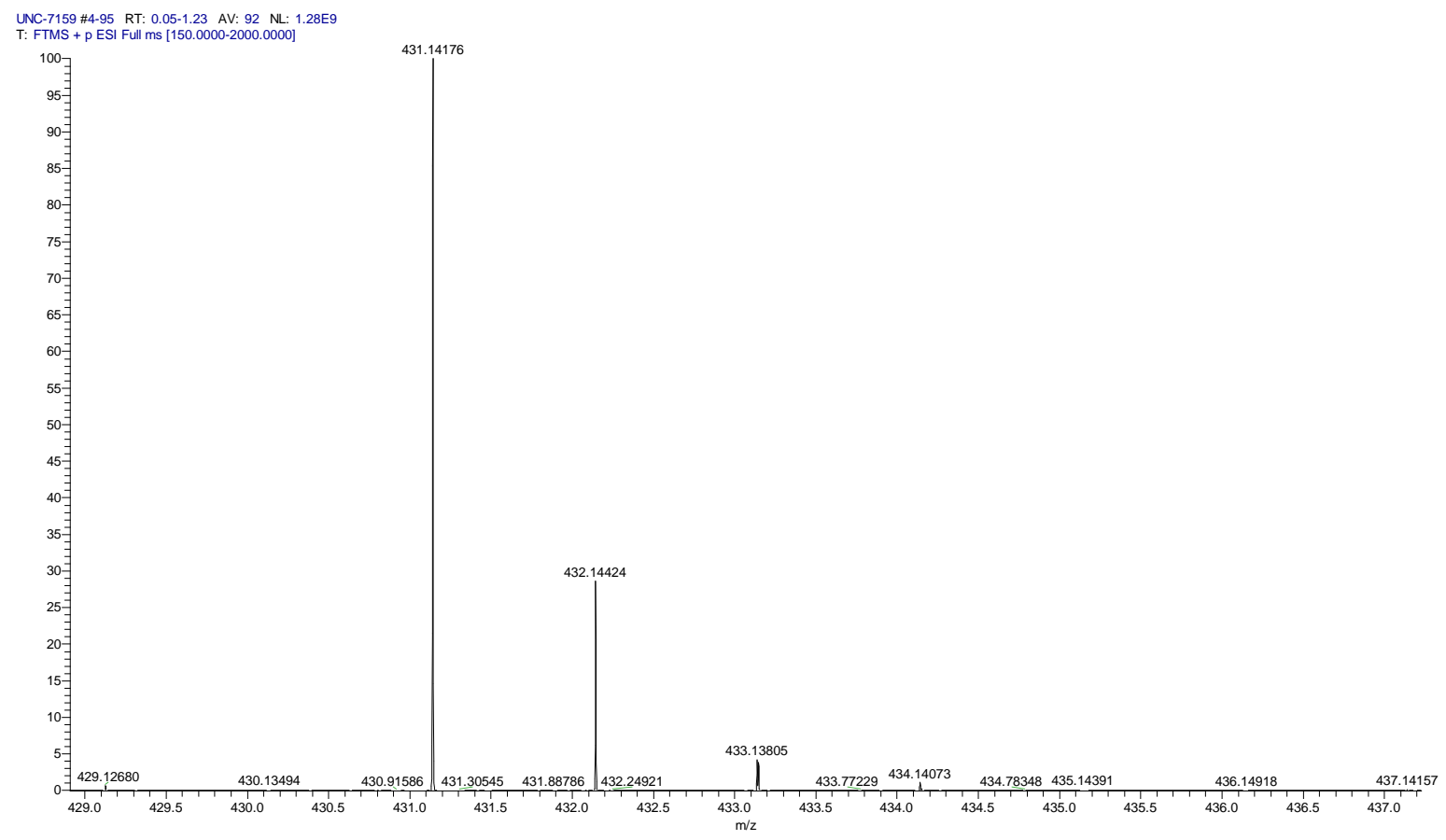

\section{Zoom Inset}

$m / z=431.14176$

mass error $=-1.5 \mathrm{ppm}$

Assigned Chemical Formula: C25H23N2O3S [M] ${ }^{+}$ 
Assessment: The observed mass and isotope peaks confirm the chemical formula assigned above. A sulfur isotope peak was observed at $+2 \mathrm{Da}$ at approximately $4 \%$ of the $[\mathrm{M}]^{+} \mathrm{m} / \mathrm{z}$ peak. A sodium adduct $[\mathrm{M}+\mathrm{Na}]^{+}$was observed at $460.19361 \mathrm{~m} / z$ as well as a [2M+H] ${ }^{+}$adduct at $861.27676 \mathrm{~m} / \mathrm{z}$.

\section{Figure S35. ${ }^{1} \mathrm{H}$ NMR and LCMS of UNC7265}
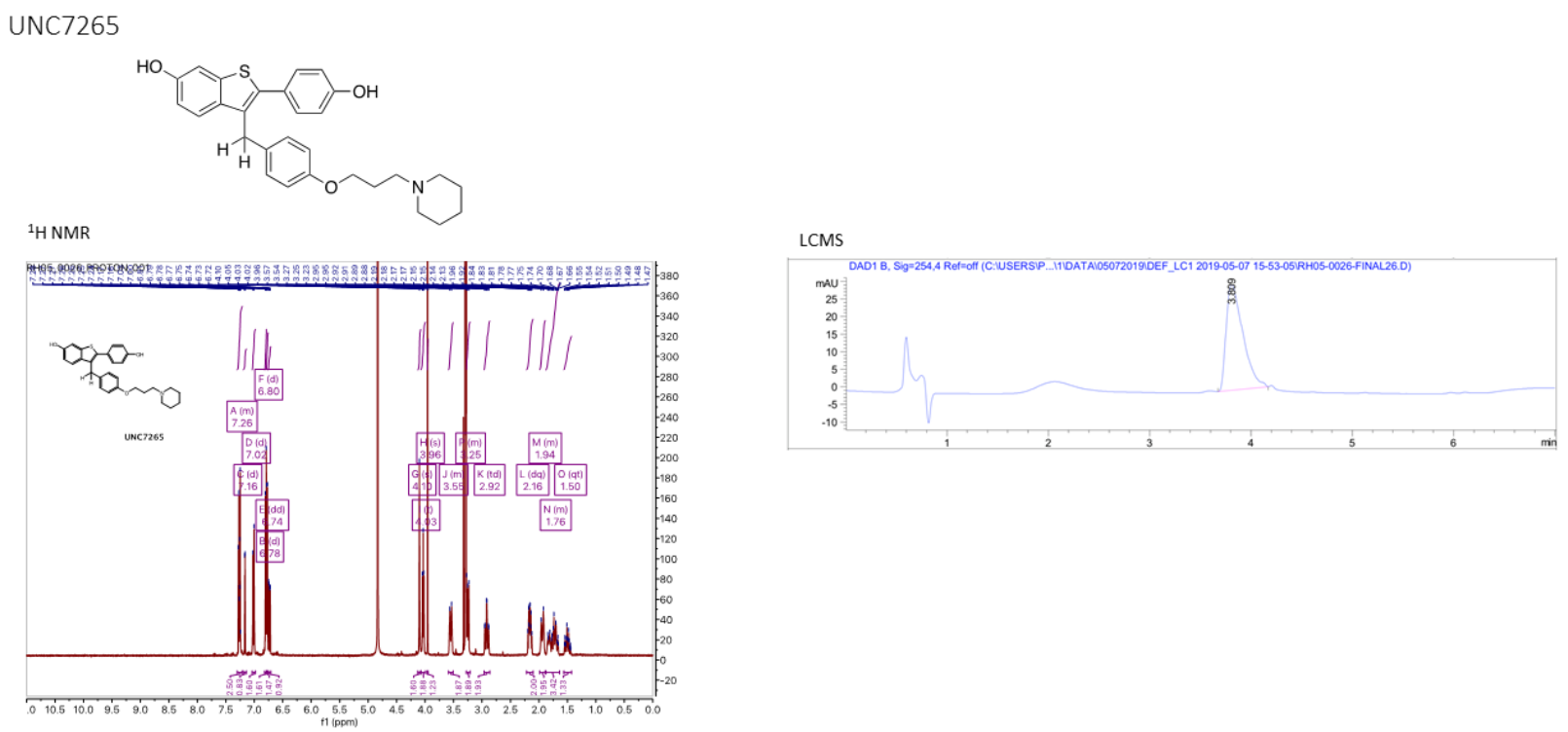

Figure S36. ${ }^{1} \mathrm{H}$ NMR and LCMS of UNC7266 


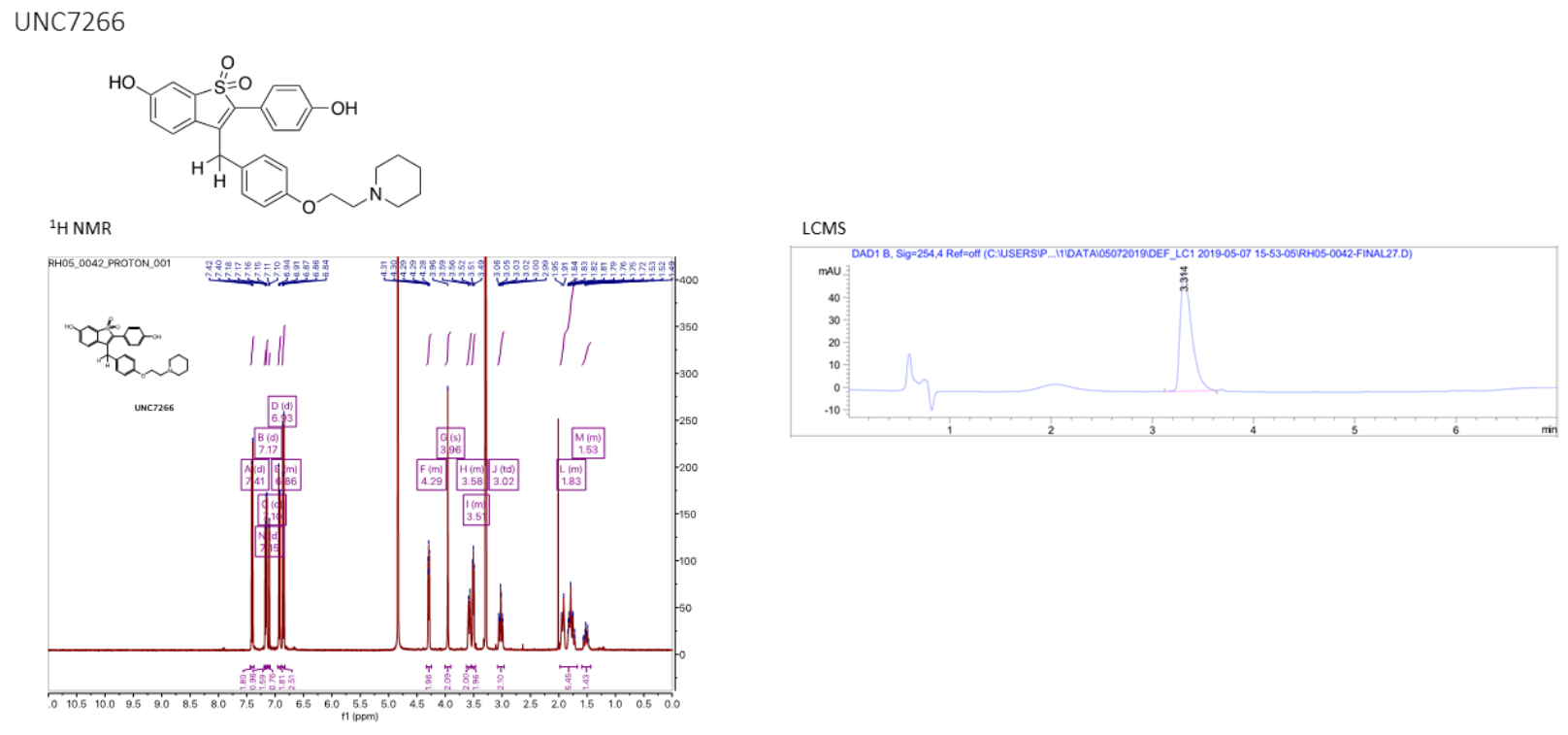

Figure S37. ${ }^{1} \mathrm{H}$ NMR and LCMS of UNC7267

UNC7267
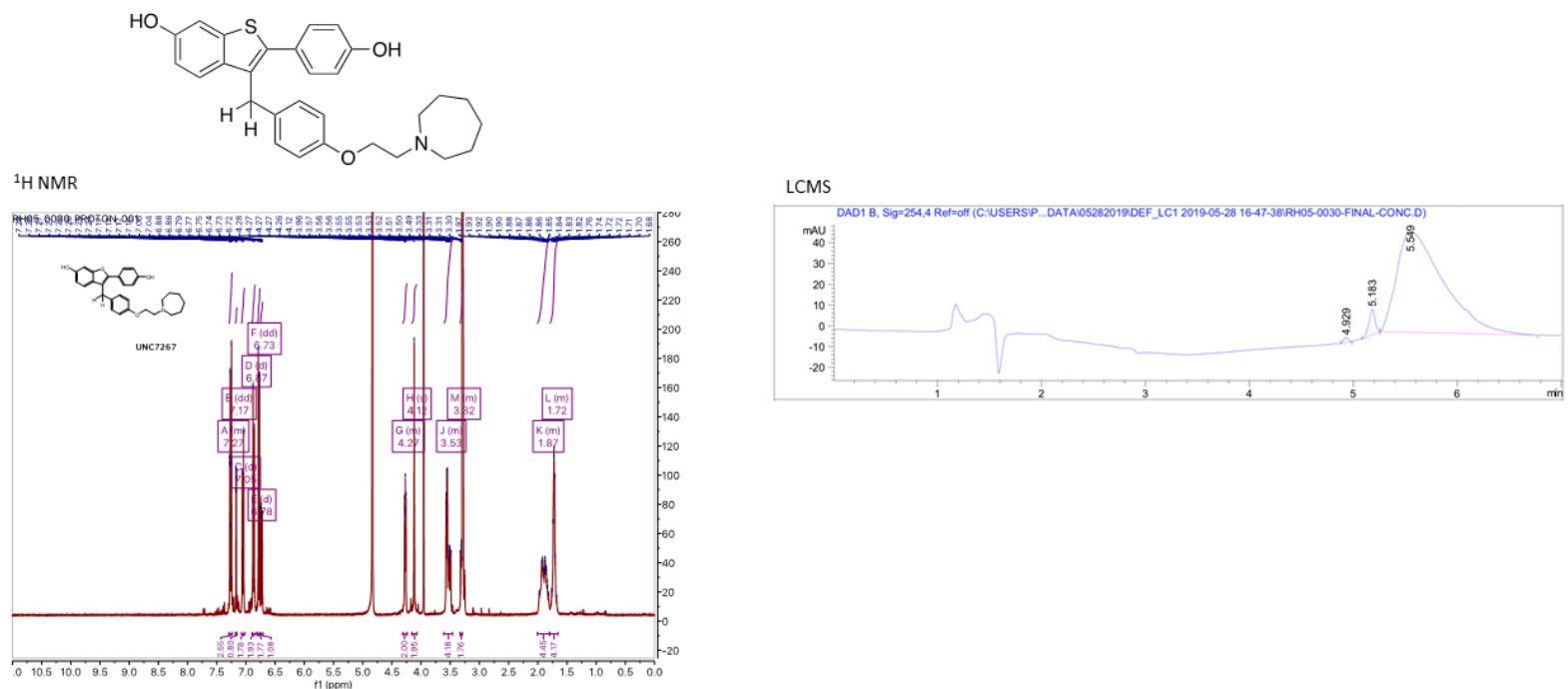

Figure S38. ${ }^{1} \mathrm{H}$ NMR and LCMS of UNC7268 
UNC7268

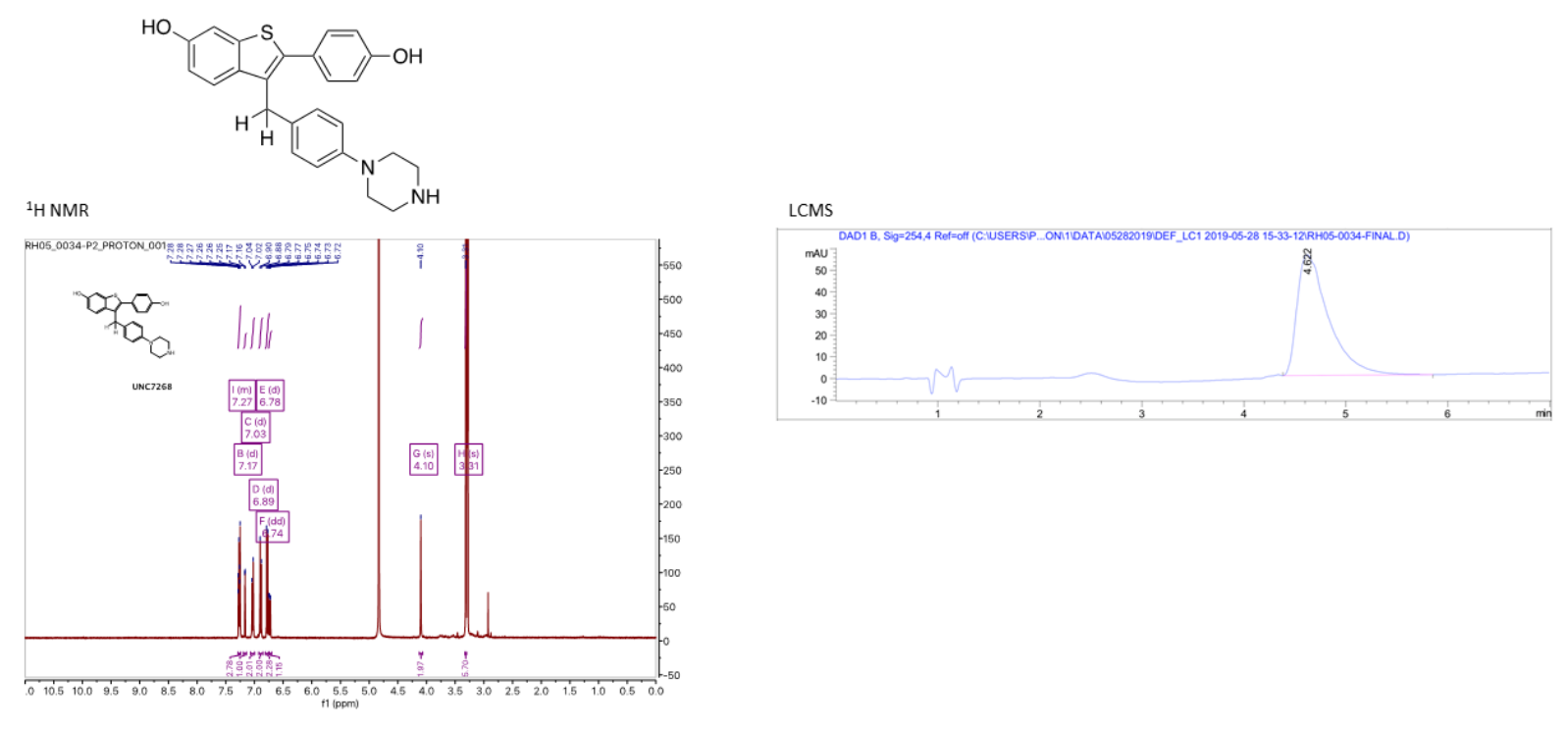




\section{Supplemental References}

1. Simpson, R. (2010). Homogenization of Mammalian Tissue. Cold Spring Harb. Protoc. 11, 1009-1012.

2. Schramm, V. (2011). Enzymatic Transition States, Transition-State Analogs, Dynamics, Thermodynamics, and Lifetimes. Annu. Rev. Biochem. 80, 703-732.

3. Little, M. S., Ervin, S. M., Walton, W. G., Tripathy, A., Xu, Y., Liu, J., \& Redinbo, M. R. (2018). Active site flexibility revealed in crystal structures of Parabacteroides merdae $\beta$ glucuronidase from the human gut microbiome. Protein Sci. 27, 2010-2022.

4. Pellock, S. J., Walton, W. G., \& Redinbo, M. R. (2019). Selecting a Single Stereocenter: The Molecular Nuances That Differentiate $\beta$-Hexuronidases in the Human Gut Microbiome. Biochemistry, 58, 1311-1317. 